\title{
THE PROPERTY/CONTRACT INTERFACE
}

\author{
Thomas W. Merrill* \\ Henry E. Smith**
}

This Article explores the distinction between in personam contract rights and in rem property rights. It presents a functional explanation for why the legal system utilizes these two modalities of rights, grounded in the pattern of information costs associated with each modality. To test this theory, the Article examines four legal institutions that fall along the property/contract interface-bailments, landlord-tenant law, security interests, and trusts-in order to determine how the legal doctrine varies as the underlying situation shifts from in personam, to in rem, to certain relations intermediate between these poles. With respect to each institution, we generally find that in personam relations are governed by flexible default rules; in rem relations are governed by bright-line rules that impose immutable and standardized obligations; intermediate relations, as befits their intermediate level of information costs, feature a type and degree of standardization beyond pure contract but short of pure property.

\section{TABLe of Contents}

INTRODUCTION . . . . . . . . . . . . . . . . . . . . . . . . . . . . . . 774

I. The Distinctive Nature of In Rem Rights ............ 780

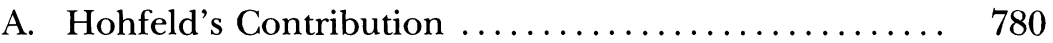

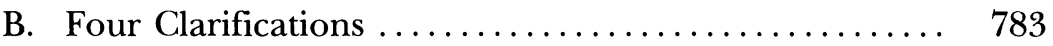

1. Numerous and Indefinite Dutyholders ......... 783

2. Rights with Respect to Things ............ 786

3. The Two-Way Nature of In Rem Rights ......... 788

4. In Rem Rights Have as Correlatives Duties of Abstention .......................... 788

II. In Personam Rights, In Rem Rights, and Information

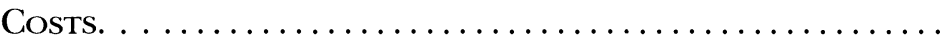

A. Why We Have Two Modalities of Rights ...........

1. The Advantages and Disadvantages of In Rem

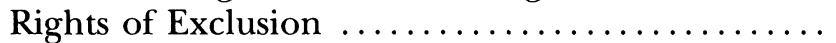

2. The Advantages and Disadvantages of In Personam Governance ............................

B. The Legal Rules Expected with Different Modalities of Rights

1. In Personam and In Rem Regimes .............

* John Paul Stevens Professor of Law, Northwestern University. B.A., 1971, Grinnell College; B.A., 1973, Oxford University; J.D., 1977, University of Chicago.

** Associate Professor of Law, Northwestern University. A.B., 1986, Harvard College; Ph.D. (Linguistics), 1992, Stanford University; J.D., 1996, Yale University. The authors would like to thank Rick Brooks, David Haddock, Jim Speta, and participants in workshops at Michigan, Northwestern, and Yale law schools for their input on earlier drafts. Thanks to Jonathan Wilson for providing research assistance. 
2. Intermediate Situations $\ldots \ldots \ldots \ldots \ldots \ldots \ldots . . \ldots 03$

III. Institutions Along the Property/Contract

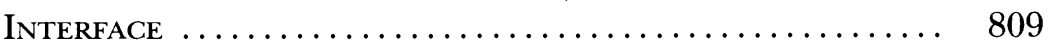

A. Bailment............................. 811

1. In Personam Relations .................... 813

2. Intermediate Relations ..................... 814

3. In Rem Relations ........................ 817

B. Landlord-Tenant Law ..................... 820

1. In Personam Relations ..................... 822

2. Intermediate Relations .................... 825

3. In Rem Relations ...................... 831

C. Security Interests ......................... 833

1. In Personam Relations ................... 836

2. Intermediate Relations .................... 837

3. In Rem Relations ..................... 842

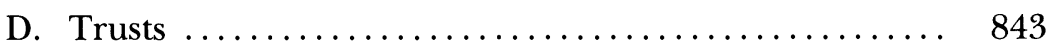

1. In Personam Relations .................... 844

2. Intermediate Relations .................... 845

3. In Rem Relations ........................ 847

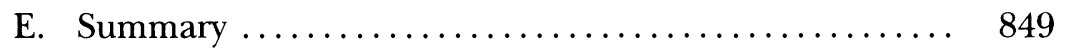

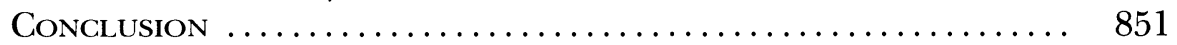

\section{INTRODUCTION}

Property and contract are bedrock institutions of the legal system, but it is often difficult to say where the one starts and the other leaves off. In constitutional law, property rights have been characterized as contracts in order to take advantage of the Contracts Clause, while contracts have been characterized as property in order to seek shelter under the Takings Clause. ${ }^{1}$ Tenants' rights lawyers have advocated replacing rules based on property with rules grounded in contract, while welfare rights lawyers have urged that government promises of benefits be deemed a species of property. ${ }^{2}$ For their part, corporate lawyers have helped create new financial markets by bundling together contract rights as "securitized" property, while extending the scope of protection for intellectual prop-

1. See E. Enters. v. Apfel, 524 U.S. 498, 528-38 (1998) (plurality opinion) (assessing retroactive impairment of employment contract under the Takings Clause); Fletcher v. Peck, 10 U.S. (6 Cranch) 87, 135 (1810) (holding that a completed grant of real property is protected by the Contracts Clause).

2. Compare John Forrester Hicks, The Contractual Nature of Real Property Leases, 24 Baylor L. Rev. 443, 446 (1972) (developing the case for treating residential leases as contracts), with Charles A. Reich, The New Property, 73 Yale L.J. 733, 778-79 (1964) (urging that government promises of benefits be treated as a form of new property). Contract rights are also often regarded as property rights for procedural due process purposes. See Thomas W. Merrill, The Landscape of Constitutional Property, 86 Va. L. Rev. 885, 991-92 (2000) [hereinafter Merrill, Landscape] and sources cited therein. 
erty through the creative use of "shrinkwrap" contracts. ${ }^{3}$ Meanwhile, legal academics carry on debates about whether institutions like corporations, bankruptcy, and trusts should be conceived of as being a nexus of contracts or a specialized type of property regime. ${ }^{4}$

All this effort at repackaging and relabeling suggests that the distinction between property and contract has important legal consequences, but also that there is considerable uncertainty about the boundary between the two bodies of law. Given the high stakes and the contested terrain, it is surprising how little attention has been given to the fundamental characteristics that distinguish property and contract as legal institutions. The foremost effort by a legal academic to understand the underlying distinction is that of Wesley Newcomb Hohfeld, ${ }^{5}$ who died at the age of 38 in 1918 before his project could be completed. ${ }^{6}$ Since then, few legally trained scholars have sought to build on this aspect of Hohfeld's work. Economists have been, if anything, even more casual, and are prone to make statements such as "[a]t the heart of the study of property rights lies the study of contracts." "When confronted with evidence that such notions may be incomplete, economists often retreat by saying that

3. On securitization, see Claire A. Hill, Securitization: A Low-Cost Sweetener for Lemons, 74 Wash. U. L.Q. 1061, 1066-77 (1996) (describing securitization of receivables and other contractual claims). On shrinkwrap licenses, see ProCD, Inc. v. Zeidenberg, 86 F.3d 1447, 1453-55 (7th Cir. 1996) (upholding a shrinkwrap licensing agreement against copyright preemption claim); Mark A. Lemley, Intellectual Property and Shrinkwrap Licenses, 68 S. Cal. L. Rev. 1239, 1241-48 (1995) (describing historical background of shrinkwrap licenses).

4. See, e.g., Melvin A. Eisenberg, The Conception That the Corporation is a Nexus of Contracts, and the Dual Nature of the Firm, 24 J. Corp. L. 819, 825-27 (1999) (outlining debate over whether corporations should be regarded in terms of property rights or contract rights); John H. Langbein, The Contractarian Basis of the Law of Trusts, 105 Yale L.J. 625, 627 (1995) [hereinafter Langbein, Contractarian Basis] (arguing that trusts are a form of third-party beneficiary contract); Alan Schwartz, A Contract Theory Approach to Business Bankruptcy, 107 Yale L.J. 1807, 1812 (1998) [hereinafter Schwartz, Contract Theory] (urging that bankruptcy be reconceived as a system of default rules subject to contractual modification).

5. Wesley Newcomb Hohfeld, Fundamental Legal Conceptions as Applied in Judicial Reasoning, 26 Yale L.J. 710 (1917). This article was reprinted in a collection of Hohfeld's essays, which in turn was reprinted in several editions. Throughout our Article, we will cite to the article as it appears in the readily available 1964 edition, Wesley Newcomb Hohfeld, Fundamental Legal Conceptions as Applied in Judicial Reasoning [hereinafter Hohfeld, Fundamental Legal Conceptions], in Wesley Newcomb Hohfeld, Fundamental Legal Conceptions as Applied in Judicial Reasoning 65-114 (Walter Wheeler Cook ed., 3d prtg. 1964) [hereinafter Hohfeld, Essays] (describing distinction between in personam and in rem rights and arguing that due to "linguistic contamination," the distinction between the two has been blurred and misunderstood).

6. See Arthur L. Corbin, Foreward to Hohfeld, Essays, supra note 5, at xiv.

7. Yoram Barzel, Economic Analysis of Property Rights 33 (2d ed. 1997) [hereinafter Barzel, Economic Analysis]. For example, Steven Cheung has argued that the principal significance of property is that it establishes the right to contract. See Steven N.S. Cheung, The Structure of a Contract and the Theory of a Non-Exclusive Resource, 13 J.L. \& Econ. 49, 67 (1970) [hereinafter Cheung, Structure]. 
the "economic" definition of property is different from the "legal" definition, ${ }^{8}$ with the implication being that they are absolved of any obligation to explain the function of the legal institution.

In a recently published article, ${ }^{9}$ we explore one pervasive difference in the legal doctrine associated with contract rights and property rights. Contract law typically permits free customization of the rights and duties of the respective parties to any contractual agreement; in other words, contract rules are generally default rules. ${ }^{10}$ Property law, in contrast, requires that the parties adopt one of a limited number of standard forms that define the legal dimensions of their relationship; generally speaking, these are mandatory rules that may not be modified by mutual agreement. ${ }^{11}$

Our explanation for this difference is based on the different costs and benefits associated with different types of rights. On the one hand, contract rights are in personam; that is, they bind only the parties to the

8. See Barzel, Economic Analysis, supra note 7, at 3.

9. Thomas W. Merrill \& Henry E. Smith, Optimal Standardization in the Law of Property: The Numerus Clausus Principle, 110 Yale L.J. 1 (2000).

10. See, e.g., E. Allan Farnsworth, Contracts $§ 1.10$, at 36 (3d ed. 1999) (stating under heading, "Most contract rules are default rules," that "[i]t is important to understand in this connection that the great bulk of the general rules of contract law, including those of the Uniform Commercial Code and the Vienna Convention, are subject to contrary provision by the parties"); Ian Ayres \& Robert Gertner, Filling Gaps in Incomplete Contracts: An Economic Theory of Default Rules, 99 Yale L.J. 87, 87 (1989) [hereinafter Ayres \& Gertner, Filling Gaps] (describing functions of larger class of default and smaller class of mandatory rules in contract); Randy E. Barnett, The Sound of Silence: Default Rules and Contractual Consent, 78 Va. L. Rev. 821, 825 (1992) (arguing that default rules, in the sense of rules subject to contractual modification, predominate both under Article 2 of the U.C.C. and in the common law of contract); Alan Schwartz, The Default Rule Paradigm and the Limits of Contract Law, 3 S. Cal. Interdisc. L.J. 389, 390-92 (1993) [hereinafter Schwartz, Default Rule] (describing the various types and functions of default rules in contract law). Mandatory rules in contract law are mainly found in the areas of fraud, duress, and unconscionability, see, e.g., Barnett, supra, at 825-26, in areas of particular regulatory concern such as insurance, see, e.g., Farnsworth, supra, $§ 1.7$, at 21 , and in the higher-order rules for what counts as contracting around a default, see, e.g., Ayres \& Gertner, Filling Gaps, supra, at 119-20; Stephen J. Ware, Default Rules from Mandatory Rules: Privatizing Law Through Arbitration, 83 Minn. L. Rev. 703, 750 \& nn.198-99 (1999) (discussing mandatory nature of rules about contracting around defaults). Moreover, some defaults are in effect closer to being mandatory in that they are difficult to contract around. See, e.g., Ayres \& Gertner, Filling Gaps, supra, at 120-24 (noting that default rules in contract law range in strength according to how explicit one must be to contract around the default); Eyal Zamir, The Inverted Hierarchy of Contract Interpretation and Supplementation, 97 Colum. L. Rev. 1710, 1738-50 (1997) (describing areas in which defaults are not easy for parties to contract around).

11. See Merrill \& Smith, supra note 9, at 9-24 (describing the numerus clausus principle and its application in American common law). The numerus clausus is a civil law principle limiting the number of types of estates. In the common law, this principle is mostly implicit. Id. at 20-23. To the extent that there is a leading case, it is Johnson v. Whiton, 34 N.E. 542, 542 (Mass. 1893) (Holmes, J.) (holding that a will devising an estate to plaintiff "and her heirs on her father's side" conveyed an unqualified fee simple title because new forms of inheritance cannot be created). 
contact. The contracting parties are in the best position to evaluate the costs and benefits of adopting novel legal terms to govern their relationship, and in the typical bilateral contract there are no significant thirdparty effects associated with the adoption of idiosyncratic terms. Property rights, on the other hand, are in rem-they bind "the rest of the world." Thus, the adoption of novel forms of property has implications not only for the immediate parties to the transaction but also for third parties, who must incur additional costs of gathering information in order to avoid violating novel property rights or to decide whether to seek to acquire these rights. Indeed, even if third parties want nothing to do with novel property rights, the very possibility that such rights exist would require them to engage in more scrutiny of the property rights they encounter in order to make sure they are not infected with unwanted novelty. Thus, free customization of property forms would create an information-cost externality; mandatory standardization is the legal system's way of reducing these external costs to an acceptable level. ${ }^{12}$

In this Article, we seek to refine and extend our thesis about the differences in legal doctrine between property rights and contract rights and the importance of information costs in explaining those differences. Our previous article proceeds as if there were a neat division within legal institutions between the regimes of contract and property, such that one can point to any particular legal relationship and say "this is a contract" or "that belongs in the world of property." But although it is possible to identify pure types of contract and property regimes, we also find numerous examples of legal institutions that are mixed or Janus-faced, partaking of characteristics that are more "contract-like" in some situations and more "property-like" in others.

The present Article focuses its investigation upon institutions that lie along this property/contract interface. Specifically, we examine the law of bailment, landlord-tenant, security interests, and trusts. Historically speaking, each of these institutions has been the subject of debate over whether it is more appropriately classified as the conveyance of a property right or an exchange of contractual promises. We are not interested in resolving these debates by establishing the "true" classification of these institutions. Rather, we take these historical debates as evidence that each of our four legal institutions is a hybrid partaking of some of the features of property rights and some of the features of contract rights. What we are interested in examining is how the legal doctrine associated with these institutions shifts as relations within each institution create information-cost patterns more like those of in personam or in rem rights.

12. We do not observe complete standardization because this would frustrate the ability of owners to do different things with their property. The restriction to a finite number of standard forms reflects a compromise between reducing third-party information costs and avoiding excessive frustration costs. See Merrill \& Smith, supra note 9 , at $38-40$. 
In order to undertake this study, it is necessary to push beyond our previous article in a number of respects. First, we need to develop a more sophisticated understanding of the in personam/in rem distinction that will allow us to analyze how the legal system adopts different structures of rights and duties in different circumstances. The in personam/in rem distinction is not limited to what are conventionally regarded as contract and property rights, but applies far more generally. For example, in personam obligations can be created by judicial judgments as well as by contracts, and in rem rights apply to interests such as bodily security as well as property. Nevertheless, the paradigmatic contract right adopts the in personam structure of rights and duties, and the paradigmatic property right corresponds to the in rem structure of rights and duties. In Part I, we draw upon the (relatively sparse) analytical literature on the distinction between in personam and in rem rights, starting with Hohfeld's discussion of "paucital" rights (i.e., primary rights in personam) and "multital" rights (i.e., primary rights in rem), in an effort to specify the distinction more precisely. Using Hohfeld's definitions as a starting point, we identify four ideal-typical forms of rights: pure in rem rights, availing against a large and indefinite class of persons; pure in personam rights, availing against singular, identified persons; compound-paucital rights, availing against numerous identified persons; and quasi-multital rights, availing against singular, unidentified persons.

Having clarified the differentiating features of in personam and in rem rights, we turn in Part II to two further questions anticipated but not fully addressed in our prior work. The first is why the legal system deploys two different structures of rights-in personam and in rem-in determining who can use scarce resources and for what purposes. Our answer is that each of these modalities does better in conserving on information costs, depending on the circumstances. Generalizing broadly, in personam rights conserve on information when it is cheaper to define permitted uses of resources directly; in rem rights conserve on information when it is cheaper to define the resource itself and appoint a single manager (the owner) who has the discretion to choose among multiple permitted uses.

The second question is what type of legal doctrine is likely to be associated with each structure of rights. Our previous article identified one important pattern: In personam rights give rise to a legal doctrine that makes heavy use of default rules while in rem rights are typically governed by the numerus clausus principle, that is to say, by a legally mandated list of immutable forms. ${ }^{13}$ Expanding on this, we would expect the legal doctrine associated with in personam rights to feature highly flexible rules designed to minimize the costs of specifying and enforcing rules for the use of resources as between identified parties, whereas in rem rights will be governed by bright-line rules designed to identify the re-

13. See Merrill \& Smith, supra note 9 , at 9-42; supra note 11. 
sources subject to such rights in a way that permits coordination among a large and indefinite number of persons. Compound-paucital or quasimultital relations represent intermediate cases, and here we would expect the law to adopt rules designed to compensate for the incomplete information of one or more of the parties. Depending on the context, this would include both rules that encourage disclosure of additional information to such parties and rules that standardize particular features of the relationship where one party is especially vulnerable due to incomplete information. We would also expect that as coordination is required among large and more indefinite groups, these rules will approach the standardization characteristic of in rem rights.

In Part III, we examine four institutions that exist along the property/contract interface: bailment, landlord-tenant law, security interests, and trusts. Our general theory about the information-cost differences between in personam and in rem rights generates one of two predicted patterns with respect to these institutions. One possibility is that, insofar as these institutions reflect a mixture of in personam and in rem rights, they will adopt legal rules that reflect a kind of muddled blend of principles associated with contract systems and property systems. In other words, the law will borrow legal concepts associated with both pure types of rights-structures, but will do so in an irregular fashion that corresponds to no clear pattern. This prediction is what one would expect to find if our theory has weak explanatory power-enough perhaps to reveal itself in the pure in personam and pure in rem situations, but not enough to reflect a decisive or consistent influence in these borderline institutions.

Another possibility is that these institutions will disclose a more consistent internal pattern. Insofar as such institutions create in personam obligations with information costs concentrated on a small number of parties, the institutions will adopt freely modifiable default rules; insofar as such institutions impose in rem obligations with more widespread informational demands, they will adopt standardized bright-line rules. Intermediate situations-what we have called compound-paucital and quasi-multital-will adopt rules that encourage disclosure of information where contracting over the rule remains a realistic option, or immutable rules designed to protect parties with incomplete information where contracting over the rule is not perceived to be a realistic option. These intermediate rules will impose more standardization as the informational demands on third parties increase. As we shall see, we find significant evidence of just such a pattern repeated across the legal doctrine of different institutions along the property/contract interface. This suggests that our theory has strong predictive power. It also tends to confirm our central claim that information costs are critical to understanding the difference between property and contract. 


\section{The Distinctive Nature of In Rem Rights}

Both civil law and common law jurisdictions have long recognized that certain legal rights are good "against the world" while others apply only against named persons or entities. ${ }^{14}$ This distinction, which has long endured across different legal systems, ${ }^{15}$ cannot be dismissed as arid conceptualism or as a matter of attaching arbitrary labels to underlying phenomena that are really the same. ${ }^{16}$ But what precisely are the differences between what we call in rem and in personam rights? Perhaps more importantly for our purposes, what are the implications of these differences in terms of the information costs that parties must incur in order to identify these rights and avoid violating them?

\section{A. Hohfeld's Contribution}

We take as our point of departure Hohfeld's pioneering article, "Fundamental Legal Conceptions as Applied in Judicial Reasoning," published in the Yale Law Journal in 1917.17 This is the second, and less familiar, of Hohfeld's two similarly titled articles. The 1917 article, which has received relatively little attention from modern scholars, ${ }^{18}$ builds on

14. Hohfeld, Fundamental Legal Conceptions, supra note 5, at 68-70 (describing in personam rights as enforceable against a person or entity and in rem rights as enforceable against the world); Albert Kocourek, Rights in Rem, 68 U. Pa. L. Rev. 322, 322 (1920) [hereinafter Kocourek, Rights in Rem] (noting influence in both civil law and common law traditions of John Austin's definition of in rem rights as "'rights residing in persons and availing against other persons generally" and related formulations including the familiar phrase "against the world").

15. Civil law systems distinguish between absolute rights and relative rights, which is similar in content to the distinction in Anglo-American law between in rem and in personam. See A.M. Honoré, Rights of Exclusion and Immunities Against Divesting, 34 Tul. L. Rev. 453, 454 (1960). See also Barry Nicholas, An Introduction to Roman Law 99-100 (1962) (explaining that modern dichotomy between in personam rights and in rem rights may have Roman origin); Fritz Schulz, Classical Roman Law 32-34, 334-35, 456 (1951) (noting that Roman law did not have modern distinction between in rem and in personam rights and that Roman law distinction between actions in rem and in personam does not exactly correspond to actions that protect these types of rights); Reinhard Zimmermann, The Law of Obligations: Roman Foundations of the Civilian Tradition 6-7 (1990) (same).

16. The distinction makes an explicit appearance only rarely in modern American legal doctrine. The particular application of the general in rem/in personam contrast that is probably best known to most lawyers is the distinction in the law of personal jurisdiction between actions in personam and actions in rem and quasi in rem. See Shaffer v. Heitner, 433 U.S. 186, 207-08 (1977) (distinguishing in personam, in rem and two types of quasi in rem actions).

17. See supra note 5 .

18. Hohfeld continues to exert fascination for legal scholars, philosophers, anthropologists, and occasionally even economists. But with the few exceptions noted in this Part, the only features of Hohfeld's system that receive much comment today are drawn from his theory of jural "opposites" and "correlatives," set forth in his 1913 article. See, e.g., Robert C. Hunt, Properties of Property: Conceptual Issues, in Property in Economic Context 7, 8-9 (Robert C. Hunt \& Antonio Gilman eds., 1998) (urging anthropologists to devote more attention to conceptual understandings of property 
and cuts across Hohfeld's familiar scheme of "jural opposites" and "jural correlatives" set forth in the earlier piece. ${ }^{19}$ Thus, for example, the notion that the concept of a legal "right" (in the sense of a right-claim) has as its necessary correlative the existence of a legal "duty" in someone else, is for Hohfeld one key to understanding the different nature of in rem and in personam rights. ${ }^{20}$

Hohfeld's first article largely eschewed invented terminology, using familiar terms like "right," "duty," "privilege," "power" and so forth, albeit with carefully specified definitions. ${ }^{21}$ When he turned his attention to explicating the differences between in personam and in rem rights, however, Hohfeld concluded that legal meanings varied greatly depending on context and had led to sloppy reasoning. ${ }^{22}$ In order to achieve the precision he desired, he found it advisable to adopt new terms to reflect the distinction in the context with which he was most interested, what he called the level of "primary rights," that is, rights that do not arise from the violation of other rights. ${ }^{23}$ Accordingly, Hohfeld coined the term "paucital" to refer to primary rights in personam, and the term "multital" to refer to primary rights in rem. We will for the most part avoid using these unfamiliar terms, although in discussing the possibility of certain

institutions, and in particular to recognize contributions of anthropologists who draw upon Hohfeld's correlatives); Madeline Morris, The Structure of Entitlements, 78 Cornell L. Rev. 822, 825 (1993) (integrating Hohfeld's theory of jural correlatives and Calabresi and Melamed's theory of entitlements); Thomas D. Perry, A Paradigm of Philosophy: Hohfeld on Legal Rights, 14 Am. Phil. Q. 41, 41 (1977) (discussing Hohfeld's analysis of conceptual relations among legal rights).

19. In the more familiar 1913 piece, also published in the Yale Law Journal, Hohfeld set forth his famous theory of jural "opposites" and "correlatives." Wesley Newcomb Hohfeld, Some Fundamental Legal Conceptions as Applied in Judicial Reasoning, 23 Yale L.J. 16 (1913) [hereinafter Hohfeld, Some Fundamental Legal Conceptions], reprinted in Hohfeld, Essays, supra note 5, at 23-64.

20. By the same token, the opposite of a right is a no-right, whose correlative in turn is a privilege. Hohfeld, Some Fundamental Legal Conceptions, supra note 19, at 38 . All the various jural relations can theoretically be in rem or in personam; thus one could have in personam (Hohfeld's paucital) or in rem (Hohfeld's multital) rights, privileges, powers, immunities, no-rights, duties, disabilities, and liabilities, for sixteen possibilities in all. Hohfeld, Fundamental Legal Conceptions, supra note 5, at 71.

21. Arthur L. Corbin, Foreword to Hohfeld, Essays, supra note 5, at vii, viii-ix.

22. Hohfeld, Fundamental Legal Conceptions, supra note 5, at 70 .

23. Primary rights are contrasted with secondary (or remedial or sanctioning) rights, i.e., rights to litigate that arise from the violation of another right (either primary or secondary). See, e.g., 1 John Austin, Lectures on Jurisprudence: The Philosophy of Positive Law 44-45 (4th ed. 1873) (distinguishing primary rights from "secondary" or "sanctioning" rights); Henry M. Hart, Jr. \& Albert M. Sacks, The Legal Process: Basic Problems in the Making and Application of Law 134-38 (William N. Eskridge, Jr. \& Philip P. Frickey eds., 1994) (comparing remedial rights with primary rights); Arthur L. Corbin, Rights and Duties, 33 Yale L.J. 501, 515-16 (1924) (distinguishing primary and secondary rights); Arthur L. Corbin, Legal Analysis and Terminology, 29 Yale L.J. 163, 171 (1919) (distinguishing secondary rights as "resulting from some operative fact that was a violation of some precedent right" from primary rights as "resulting from some operative fact that was not itself a violation of some precedent right"). 
intermediate types of right-structures we will find it convenient to adopt variations on Hohfeld's terminology.

Hohfeld defined a primary right in personam, or paucital right, as "a unique right residing in a person (or group of persons) and availing against a single person (or single group of persons); or else it is one of the few fundamentally similar, yet separate, rights availing respectively against a few definite persons." ${ }^{24} \mathrm{He}$ defined a primary right in rem, or multital right, as "one of a large class of fundamentally similar yet separate rights, actual and potential, residing in a single person (or single group of persons) but availing respectively against persons constituting a very large and indefinite class of people." 25 As an example of a paucital right he cited the case of an ordinary bilateral contract: "If B owes A a thousand dollars, A has an affirmative right in personam, or paucital right, that $B$ shall do what is necessary to transfer to A the legal ownership of that amount of money." 26 As an example of a multital right, he cited the case of ordinary ownership of land: "If A owns and occupies Whiteacre, not only B but also a great many other persons-not necessarily all persons-are under a duty, e.g., not to enter on A's land. A's right against B is a multital right, or right in rem, for it is simply one of A's class of similar, though separate, rights, actual and potential, against very many persons." 27

Hohfeld went on to offer a number of clarifying points about in rem rights, some of which have since entered into conventional wisdom. For example, he explained that rights in rem are not really rights "against a thing." ${ }^{28}$ Rather, such rights, like all "jural relations," apply to persons. ${ }^{29}$ Moreover, in rem rights are not necessarily related to a thing, in the sense of a tangible object. Such rights can also exist in intangibles, such as intellectual property. Indeed, Hohfeld noted that rights to bodily integrity, individual liberty, and even rights of consortium and personal privacy can also be conceived of as being rights in rem. ${ }^{30}$ Thus, in rem rights are not unique to property but exist whenever someone has a right that holds against a large and indefinite class of others, as opposed to specifically identified others.

Hohfeld also explained that in rem rights in a particular subject matter can coexist with a variety of other privileges, powers, and immunities. Any of Hohfeld's eight jural conceptions-rights, duties, privileges, norights, powers, liabilities, immunities, and disabilities-can be in rem or

24. Hohfeld, Fundamental Legal Conceptions, supra note 5, at 72 (footnotes omitted). Hohfeld based his neologism on the Latin paucus, which means "few" or "little."

25. Id. (emphases omitted).

26. Id. at 73 (emphases omitted).

27. Id. (emphases and footnotes omitted).

28. The Latin phrase "in rem" literally means "against a thing," whereas "in personam" means "against a person." Black's Law Dictionary 797, 795 (7th ed. 1999).

29. Hohfeld, Fundamental Legal Conceptions, supra note 5, at 75 .

30. Id. at 85 . 
in personam, ${ }^{31}$ but he focused on in rem and in personam rights and their corresponding duties. Although Hohfeld did not adopt the metaphor of a "bundle of rights,"32 his discussion of how fee simple ownership of land can be broken down into a complex of jural relations ${ }^{33}$ directly anticipates the adoption of the bundle-of-rights metaphor favored by the Legal Realists. ${ }^{34}$ His treatment of this aspect of property is also a direct antecedent of the similar conception of property set forth in the opening passages of the First Restatement of Property. ${ }^{35}$

\section{B. Four Clarifications}

Certain aspects of Hohfeld's discussion of the in personam/in rem distinction have been subject to criticism, and others have been further elaborated. Drawing upon these accounts, we offer four clarifications of Hohfeld's explication of the nature of in rem rights: (1) in rem rights are characterized by both an indefinite class of dutyholders and by large numbers of dutyholders; (2) in rem rights are not simply aggregations of in personam rights but are qualitatively different in that they attach to persons through their relationship to particular things rather than as persons; (3) in rem rights are numerous and indefinite in two directionsnot only does each in rem right give rise to a large and indefinite number of dutyholders, but also each dutyholder holds such duties to a large and indefinite number of rightholders; and (4) in rem rights are always claims to abstentions by others as opposed to claims to performances on the part of others.

1. Numerous and Indefinite Dutyholders. - The first clarification relates to Hohfeld's conception of numerous and indefinite dutyholders. Writing in the early 1920s, Professor Albert Kocourek of Northwestern University School of Law objected to Hohfeld's suggestion that in rem rights necessarily apply to large numbers of persons. ${ }^{36}$ Kocourek pointed out that it is possible to imagine cases in which only one person is subject to an in rem right: for example, where A, "a land owner, has granted an easement to every person in the state to walk across his land except to

31. Id. at 67,71 ; see also supra note 20 .

32. Greg Alexander has traced the first known use of the metaphor to a late nineteenth-century treatise on eminent domain. Gregory S. Alexander, Commodity \& Propriety: Competing Visions of Property in American Legal Thought, 1776-1970, at 455 n.40 (1997) (citing John Lewis, A Treatise on the Law of Eminent Domain in the United States 43 (1888)).

33. Hohfeld, Fundamental Legal Conceptions, supra note 5, at 96-97.

34. See Thomas C. Grey, The Disintegration of Property, in Property: Nomos XXII 69 (J. Roland Pennock \& John W. Chapman eds., 1980).

35. Restatement of Property $\S \S 1-4$ (1936) (distinguishing "right," "privilege," and "power" as different interests in property); id. $§ 10$ ("The word 'owner,' as it is used in this Restatement, means the person who has one or more interests.").

36. See Kocourek, Rights in Rem, supra note 14, at 332. 
B." 37 Given that such a case could be imagined, Kocourek argued that the key to in rem rights must be that the identity of the dutyholder is indefinite, not that the dutyholders are necessarily numerous. ${ }^{38}$ Kocourek accordingly proposed that a primary right in rem be defined as "one of which the essential investitive facts do not serve directly to identify the person who owes the incident duty." 39

Kocourek's criticism does not have much force with respect to the ordinary case of in rem rights, which is full ownership of property. If A owns Blackacre, then it is not merely that there is an indefinite number of persons subject to a duty not to trespass on Blackacre. In addition, the number of persons potentially subject to such a duty will, in the ordinary case, be very large: every person who might at some future time come into physical contact with Blackacre. Kocourek's counterexample of real property subject to an easement in all persons save one is rather fantastical, and certainly does not defeat Hohfeld's intuition that in virtually every real-world case, in rem rights will attach to a large number of dutyholders. ${ }^{40}$ Thus, Hohfeld's inclusion of numerosity as well as indefiniteness in defining the classic example of an in rem right appears to be warranted.

Nevertheless, we think Kocourek was on to something in suggesting that numerosity may be a contingent variable that is not present in all

37. Id. Note that this example does not mean that A affirmatively excludes B, but rather that A has affirmatively included all others, leaving only B subject to A's in rem rights of property.

38. Id. at 335. Both Hohfeld's and Kocourek's theories have antecedents in Austin's view about property that "indefiniteness is of the very essence of the right; and implies that the right ... cannot be determined by exact and positive circumscription." 2 John Austin, Lectures on Jurisprudence 827 (Robert Campbell ed., 4th ed. 1873). This indefiniteness can characterize the set of uses available to the owner. See Restatement of Property $\S 5$ $\mathrm{cmt}$. e, $\S 10 \mathrm{cmt}$. c (1936) (stating that while at any given time there is a maximum combination of rights, powers, and privileges that an owner enjoys in his property, an owner may part with some of those rights and will retain ownership); Bernard E. Jacob, The Law of Definite Elements: Land in Exceptional Packages, 55 S. Cal. L. Rev. 1369, 1388 (1982) (discussing how Restatement definition of complete ownership requires "not only reasonably exclusive present control, but also an indefinite reservoir of potential uses").

39. Kocourek, Rights in Rem, supra note 14, at 335. Kocourek agreed with Hohfeld about the need for new terminology to describe rights in personam and rights in rem, but because he did not regard the element of numerosity as being inherent in the underlying concepts, he objected to "paucital" and "multital." Kocourek proposed the terms "polarized" and "unpolarized" instead. See Albert Kocourek, Polarized and Unpolarized Legal Relations, 9 Ky. L.J. 131, 131 (1921).

40. One reason that Kocourek's hypothetical is unrealistic is that the least-cost method of allowing everyone but B onto Blackacre would normally involve identifying and excluding B, as one does in setting up in personam rights. The force of Kocourek's hypothetical depends on the goal of a theory of in rem rights. If the goal is to delineate necessary and sufficient conditions that will capture all cases of an on/off distinction, then the hypothetical is troubling. If on the other hand, one is interested in explaining on the basis of costs and benefits why certain features place certain rights more towards one or the other end of a spectrum from in rem to in personam rights, then Kocourek's example poses no great problem. 
situations. Consider some cases not mentioned by Kocourek. Suppose one of the parties to an in personam relationship assigns her rights to a third party; for example, a tenant assigns her interest under a lease with a landlord to a third party. From the perspective of the landlord contemplating the possibility of such an assignment, the identity of the third party is indefinite, but the number of actual assignees is likely to be small (usually, of course, one). Or consider a bailor who transfers property to a bailee, who then misdelivers the property to a third party. Again, from the perspective of the bailor, the identity of the third party is indefinite, but in nearly all cases will be a single person or entity.

These fairly common situations provide more plausible illustrations of Kocourek's suggestion that rights can be indefinite yet singular. Notice, however, that we would not ordinarily describe these situations as involving in rem rights. We do not have any special name for them; they are just cases of assignment or misdelivery or whatever. The fact that we do not consider these situations as in rem provides additional confirmation that both indefiniteness and numerosity of dutyholders must be present in the case of a pure in rem right.

We can carry the analysis of contingency of conditions one step further. Not only is it possible to identify cases in which dutyholders are indefinite but singular, but it is also possible to identify cases in which either the dutyholders or the rightholders are definite but numerous. A single seller who enters into a large number of identical standard-form contracts with numerous buyers provides one possible illustration; a class action lawsuit perhaps provides another. ${ }^{41}$

In fact, if we think of definiteness and numerosity of dutyholders as two contingent variables that are jointly necessary to establish pure in rem rights, we can see that there are in fact four modalities of rights with respect to these variables. There are the two polar cases: rights that are definite and singular (pure in personam or paucital rights), and rights that are indefinite and numerous (pure in rem or multital). But there are also two intermediate cases. There are rights that are definite but numerous-what might be called "compound-paucital" rights, illustrated by the example of a standard-form contract. And there are rights that are indefinite but singular — what might be called "quasi-multital" rights, illustrated by the example of a lease assignment. We present these four modalities in the two-by-two matrix shown in Figure 1.

41. Fed. R. Civ. P. 23. Most class actions involve multiple but identifiable plaintiffs, but it is also possible to have a class action with multiple but identifiable defendants. See, e.g., Williams v. State Bd. of Elections, 696 F. Supp. 1574, 1576-77 (N.D. Ill. 1988) (explaining that defendant classes may be certified under either Rule 23(b) (1) or Rule 23(b) (3)); 5 James Wm. Moore et al., Moore's Federal Practice $§ 23.45$ [3] (3d ed. 2000) (“A defendant class may be certified under Rule 23(b) (3)."); Scott Douglas Miller, Note, Certification of Defendant Classes Under Rule 23(B)(2), 84 Colum. L. Rev. 1371, 1371 (1984) (examining the text, history and policies underlying the rule and arguing that "[t]hese conclusively establish that Rule 23(b)(2) authorizes defendant class certification."). 
Figure 1. Modalities of Rights

\begin{tabular}{|c|c|c|c|}
\hline & & \multicolumn{2}{|c|}{ Numerosity } \\
\hline & & Nonnumerous & Numerous \\
\hline \multirow[t]{2}{*}{ Definiteness } & Definite & $\begin{array}{l}\text { Paucital: e.g., } \\
\text { bilateral contract }\end{array}$ & $\begin{array}{l}\text { Compound-paucital: } \\
\text { e.g., standard-form } \\
\text { contract }\end{array}$ \\
\hline & Indefinite & $\begin{array}{l}\text { Quasi-multital: e.g., } \\
\text { assignment, } \\
\text { misdelivery }\end{array}$ & $\begin{array}{l}\text { Multital: e.g., fee } \\
\text { simple in Blackacre }\end{array}$ \\
\hline
\end{tabular}

Breaking apart the differentiating features of in rem rights in this fashion allows us to see that the world does not consist simply of in personam and in rem rights, but also includes intermediate cases. Since both "indefiniteness" and "numerosity" are matters of degree, the number of intermediate cases is probably very large and presumably falls along a continuum. Thus, our intermediate cases should not be regarded as pure types in the same way that Hohfeld's paucital rights and multital rights can be considered pure types.

2. Rights with Respect to Things. - Hohfeld conceived of in rem rights as a kind of cluster bomb of actual and potential in personam rights. In other words, Hohfeld thought that in rem rights can be broken down into a large and indefinite number of individual in personam right/duty relations. ${ }^{42}$ According to Hohfeld, all paucital and multital rights can be formed by grouping together sets of fundamentally similar yet distinct rights; a paucital right is simply one that corresponds to a special type of "uncompanioned" duty in a single or small number of individuals. ${ }^{43}$

Hohfeld has been criticized for suggesting that in rem rights are qualitatively indistinguishable from in personam rights. Modern analytic

42. As he put it: "A single multital right, or claim (right in rem), correlates with a duty resting on one person alone, not with many duties (or one duty) resting upon all the members of a very large and indefinite class of persons." Hohfeld, Fundamental Legal Conceptions, supra note 5, at 91 (emphasis omitted). The idea that Hohfeld appeared to be resisting in taking this position was that multital duties are in some sense "joint." As he noted, A's multital right as the owner of Blackacre does not give rise to a joint duty among $\mathrm{B}, \mathrm{C}$, or D not to enter on Blackacre. This is because A could grant B a license to enter, and this would not in any way extinguish the duties of $C$ or $D$, which would continue "precisely as before." Hohfeld, Fundamental Legal Conceptions, supra note 5, at 93-94. In an effort to head off the error of conceiving of multital duties as joint, however, Hohfeld embraced a characterization of multital duties that appears to distort the inherent features of multital interests.

43. For Hohfeld, a paucital right corresponds to a duty in one single person (or group of persons), or else the right is one of "a few fundamentally similar, yet separate, rights availing respectively against a few definite persons." Hohfeld, Fundamental Legal Conceptions, supra note 5 , at 72 . For the subset of paucital rights availing against a single dutyholder, Hohfeld suggested the term "unital." See id. at $72 \&$ n.18. Thus, the difference between unital, non-unital but paucital, and multital rights was merely the number of fundamentally similar yet distinct rights that were grouped together. 
philosophers, most prominently J.E. Penner, have argued that in personam and in rem rights are in fact qualitatively different in at least one important respect: In personam rights attach directly to specific persons, whereas in rem rights attach to persons only because of their relationship to a particular "thing." ${ }^{4}$ In rem rights may be rights against persons rather than things, as Hohfeld argued, but the persons who are so bound are identified by their relationship to a thing. For example, if A sells Blackacre to $\mathrm{B}$, this does not result in any change in the duties of third parties W, X, Y, or Z toward Blackacre. Those duties shift silently from A to $\mathrm{B}$ without any requirement that $\mathrm{W}, \mathrm{X}, \mathrm{Y}$, or $\mathrm{Z}$ be aware of the transfer, or even of the identities of A or B. ${ }^{45}$ Similarly, if the thing that identifies the existence of in rem rights disappears or is destroyed, the rights and duties in rem disappear with it, leaving (at most) only in personam rights and duties (e.g., an in personam action for trespass or trover against the person who took or destroyed it). As Penner puts it, "“[t]hings' . . . whether physical things or states of affairs such as bodily security, mediate between rights in rem and duties in rem, blocking any content which has to do with the specific individuality of particular persons from entering the right-duty relation." 46

Penner is correct that Hohfeld's conception of in rem rights as simply an aggregation of in personam rights misses a fundamental aspect of in rem rights. The duty to respect the property of others (and other interests such as bodily security and privacy of others) has an impersonality and generality that is qualitatively different from duties that derive from specific promises or relationships. Moreover, this general duty to respect the property and security of others would seem to perform extremely important social functions. As Penner observes:

Norms in rem establish the general, impersonal practices upon which modern societies largely depend. They allow strangers to interact with each other in a rule-governed way, though their dealings are not personal in any significant respect. Grasping this point is absolutely vital to grasping legally recognized practices like property. ${ }^{47}$

44. J.E. Penner, The Idea of Property in Law 25-31 (1997) [hereinafter Penner, Idea of Property]; see also Kenneth Campbell, On the General Nature of Property Rights, 3 King's C. L.J. 79, 84-89 (1992) (discussing scholarship on the difference between in rem rights and in personam rights, and arguing for a qualitative distinction between the two); Honoré, supra note 15, at 455-57 (critiquing Hohfeld's conception of rights and claims); J.E. Penner, The "Bundle of Rights" Picture of Property, 43 UCLA L. Rev. 711, 728 (1996) (describing and questioning Hohfeld's conception of the disctinction between in rem rights and in personam rights).

45. See Campbell, supra note 44 , at 88 (noting that with respect to in rem rights "further persons may become persons against whom the right holds, irrespective of whether any other person has ceased to be a person against whom the right holds").

46. Penner, Idea of Property, supra note 44, at 29.

47. Id. at 30. 
3. The Two-Way Nature of In Rem Rights. - A third clarification concerns a point that is mostly implicit in Hohfeld's account, and is explicit, but not given sufficient emphasis, in Penner's. ${ }^{48}$ In rem rights involve a large and indefinite number of persons not only from the perspective of the rightholder, considering the world of persons who are subject to duties to respect the rightholder's control over some thing. They also involve a large and indefinite number of persons from the perspective of the dutyholders, looking out over the world consisting of persons who hold rights in rem. Penner suggests as much when he observes that "in general, it is completely unknown to us whether any given amount of property is owned by one person or by several or many. ... We are under one duty to the plurality of property holders however their property is distributed amongst themselves." 49

In rem rights, in other words, involve indefiniteness and numerosity in two directions. There is (usually) only one owner of a thing. This ownership is protected against interference from a large and indefinite class of dutyholders. But each dutyholder also confronts a world containing a large and indefinite class of owned things. In rem rights thus present a potentially massive coordination problem. Each person in society has in rem rights that must be protected against a large and indefinite number of potential violators. At the same time, each person must respect the in rem rights of a large and indefinite class of others. This feature of in rem rights, in particular, has implications for the information-cost constraints associated with establishing any system of rights that has in rem features.

4. In Rem Rights Have as Correlatives Duties of Abstention. - Finally, extending an assertion of Hohfeld's, A.M. Honoré has observed that in rem rights are always negative in character: They require that persons abstain from certain types of interference with a thing or status. ${ }^{50}$ " $[\mathrm{T}]$ here appears to be no instance, either in the Anglo-American or con-

48. Hohfeld anticipates the numerosity of rightholders from the perspective of a dutyholder when he distinguishes multital from general:

It is submitted . . . that according to the best usage the term "general," as applied to a jural relation, indicates that the latter is one of a large class of similar relations residing respectively in many persons, i.e. people in general. For example, any duty correlating with a multital right would be a general, or common, duty. The right of a person not to be struck by another is both multital and general.

Hohfeld, Fundamental Legal Conceptions, supra note 5, at 72 n.20. Sadly, Hohfeld leaves off here, promising that " $[\mathrm{t}]$ his matter will receive more complete consideration at a later time." Id.

49. Penner, Idea of Property, supra note 44, at 27.

50. See Honoré, supra note 15, at 458-59; see also Wesley Newcomb Hohfeld, Faulty Analysis in Easement and License Cases, 27 Yale L.J. 66, 71-72 (1917) (observing that a landowner is not required to exercise reasonable care to protect property stored on his land from harm caused by negligent use of adjacent land); Hohfeld, Fundamental Legal Conceptions, supra note 5, at 72 (defining paucital and multital rights and claims); Jacob, supra note 38 , at 1378 n.40 ("Hohfeld's position on affirmative obligations relates directly to his belief that property was paradigmatically constructive rather than consensual. The 
tinental lists, of a right protected by a claim that persons generally should perform something." ${ }_{1}$ Thus, for example, the in rem rights associated with tangible property "all are claims to exclude others and prevent others from doing acts." ${ }^{2}$ Similarly, in rem rights of bodily security or privacy are claims that others desist from certain types of intrusions upon the protected interest. Where affirmative obligations to engage in certain performances arise, whether it be to perform in an opera or provide support to dependent children, they are usually in personam: They impose a singular duty on an identified person. ${ }^{53}$

Of course, there are also claims to abstentions that are in personam. A covenant not to compete provides one example. In personam obligations can be either duties of performance or abstention. But in rem obligations, at least with respect to the ownership of property, seem always to assume the form of negative duties of abstention.

In sum, we would modify Hohfeld's analysis of the distinction between in rem and in personam rights by emphasizing four differentiating features of in rem rights: (1) in rem rights apply to a large and indefinite class of dutyholders; (2) in rem rights attach to persons only insofar as they own particular "things" and not otherwise; (3) all persons hold in rem duties to a large and indefinite class of holders of such rights; and (4) in rem duties are always duties of abstention rather than performance.

\section{In Personam Rights, In Rem Rights, and Information Costs}

Although one can say that in rem rights are good against the world, and this formulation can be refined along the lines set forth in Part I, the question remains why some rights are of the in rem modality and others are in personam. Why do we find this fundamental and widespread difference in the structure of rights and why do contract rights (typically) adopt one modality and property rights (typically) adopt the other? In this Part we sketch out some functional reasons for having a legal system that includes both in rem and in personam rights with respect to control over the use of resources. This sketch builds generally on work by one of us on the characteristic costs and benefits of defining rights on the basis

argument he is making is that few affirmative, as opposed to negative, obligations ought to be broadcast. Hohfeld has in mind something like the obligation to join a posse.").

51. Honoré, supra note 15 , at 459. For judicial recognition of this point, see LeRoy Fibre Co. v. Chicago, Milwaukee \& St. Paul Ry., 232 U.S. 340, 348-52 (1914) (holding that landowner has no affirmative obligation to modify use of his land so as to minimize harm caused by negligence of another).

52. Honoré, supra note 15 , at 458.

53. There are some affirmative obligations, such as an obligation to maintain a common wall, that "run with the land" and thus can be said to be quasi-multital-they are singular but indefinite. See generally Charles E. Clark, Real Covenants and Other Interests Which "Run With The Land" 144-69 (2d ed. 1947) (discussing arguments concerning whether party-wall covenants should be allowed by courts to run with the land). But there are few if any affirmative obligations that are purely in rem. 
of rule-governed use of resources versus exclusive access to a resource. ${ }^{54}$ Sometimes speci'ic users of a resource are identified and their use governed by use restrictions, and at other times a resource is defined and an owner is delegated control by means of the right to exclude. ${ }^{55}$ We expect the structure of rights over the resource to tend towards cost effective use of each strategy. In particular, in personam contract rights, which represent a type of governance strategy, will be used when it is cost effective to impose a relatively large informational burden on a small number of identified people; in rem rights to property, which constitute a type of exclusion strategy, will be used when it is cost effective to impose a small informational burden on a large and indefinite number of people. We further argue that the information costs associated with each of these modalities of rights are likely to affect the legal doctrine that governs each type of right: In personam rights will be governed by flexible legal rules that minimize the costs of tailoring rights and obligations to each particular situation, whereas in rem rights will be governed by bright-line rules that allow large and indefinite numbers of people to identify owned resources at low cost. ${ }^{56}$

\section{A. Why We Have Two Modalities of Rights}

In personam contract rights and in rem property rights can be seen as two different strategies for regulating the use of resources. The in personam strategy proceeds by directly specifying use rights as between specified individuals. It indicates which of the designated individuals is entitled to engage in which uses of particular resources. By contrast, the in rem strategy establishes use rights in two stages. First, it identifies particular resources ("things"), and specifies which person (the "owner") is to act as the gatekeeper or regulator of the thing. ${ }^{57}$ Then this owner determines, in a relatively unconstrained fashion, which individuals can engage in which uses of the resource. ${ }^{58}$

54. See Henry E. Smith, Two Dimensions of Property Rights 3-7 (November 29, 2000) (unpublished manuscript, on file with the Columbia Law Review) [hereinafter Smith, Two Dimensions].

55. In this Article, we will examine the exclusion/governance dichotomy only as a means of explaining the existence of in rem and in personam rights. Further discussion of these different strategies for defining rights is beyond the scope of this Article.

56. This accords with our prior work on the numerus clausus principle in which we explain that principle as a response to the information-cost implications of relatively anonymous in rem property rights. See Merrill \& Smith, supra note 9 , at 8.

57. See, e.g., Penner, Idea of Property, supra note 44, at 74 (using gatekeeper metaphor for property); Thomas W. Merrill, Property and the Right to Exclude, 77 Neb. L. Rev. 730, 749 (1998) (adopting the gatekeeper metaphor to explain the distinctive nature of property rights).

58. That is, the owner or "gatekeeper" is free to select uses and users subject only to general constraints that the law imposes on general behavior (for example, one is not allowed to use a car to run someone over). Cf. Jeremy Waldron, The Right to Private Property 32-33 (1988) (arguing that general rules against using property in ways that harm others are not properly considered elements of the definition of property). Moreover, one 
Viewed in this way, in personam contract rights and in rem property rights are species of two more general strategies for regulating resource use: In personam rights are an instance of what can be called a governance strategy for determining use rights; in rem rights reflect an exclusion strategy for determining use rights. Under a governance strategy, rights to resources are defined in terms of permitted and restricted uses. Some examples of governance include the in personam rights imposed by contracts, the in personam rights imposed by courts, ${ }^{59}$ government licenses that control the use of particular resources, ${ }^{60}$ and some of the informal norms and formal regulations relating to particular uses of resources. ${ }^{61}$ Governance rules typically specify particular uses in some detail, including often the identity of the rightholder and the dutyholder. Indeed, often the dutyholder will need to know the identity of the rightholder in order to avoid violating the duty.

Exclusion strategies, by contrast, proceed by restricting access to a particular resource rather than by specifying permitted or prohibited uses. Exclusion identifies a person or entity as the manager of a resource (the owner), and then delegates to this manager the discretion to select from among an open-ended set of potential uses. Groups typically delineate and enforce exclusion rights over resources by using rough proxies, such as territorial boundaries, that bunch together a class of uses such that only the owner needs to measure them separately if at all. ${ }^{62}$ One example of exclusion occurs where groups restrict access to resources, such as where a particular community restricts a fishing ground to mem-

can view governance and exclusion as forming poles on a spectrum according to how few or how many uses are left to the discretion of the rightholder. See Smith, Two Dimensions, supra note 54 , at 3 .

59. The rights imposed by courts would include not only those arising under judgments but also those stemming from consent decrees and settlements.

60. See Orin S. Kerr, Rethinking Patent Law in the Administrative State, 42 Wm. \& Mary L. Rev. 127, 141-43 (2000) (contrasting the function of government licenses with government-created property rights like patents).

61. On the role of social norms in controlling behavior with respect to resources, see, e.g., Robert C. Ellickson, Order Without Law: How Neighbors Settle Disputes 167-83 (1991) (hypothesizing that "members of tight social groups will informally encourage each other to engage in cooperative behavior"); Elinor Ostrom, Governing the Commons: The Evolution of Institutions for Collective Action 29-57 (1990) (examining institutional solutions to problems of allocating "common-pool resources"); James M. Acheson, Management of Common-Property Resources, in Economic Anthropology 351 (Stuart Plattner ed., 1989); Carol Rose, The Comedy of the Commons: Custom, Commerce, and Inherently Public Property, 53 U. Chi. L. Rev. 711, 739-49 (1986) [hereinafter Rose, The Comedy of the Commons] (tracing the role of custom in managing the commons).

62. Smith, Two Dimensions, supra note 54. Relatedly, Ellickson has noted that territorial boundaries are cheap to defend because one can train a dog to guard them, whereas norms of good behavior require judgment that is beyond a dog's capacity. Robert C. Ellickson, Property in Land, 102 Yale L.J. 1315, 1329 (1993) [hereinafter Ellickson, Property in Land]. 
bers of the community. ${ }^{63}$ Another example is where groups informally divide a resource into separate territories in accordance with social norms, such as the right of a particular member of the community to exclusive use of a particular plot of land. ${ }^{64}$ And a third example would be an in rem property right backed by the force of law, such as the conventional legal property right of quiet enjoyment.

For any given issue of resource use, the choice between governance and exclusion will depend on the advantages and disadvantages of using different versions of these strategies in the particular context. Each strategy has certain characteristic advantages and disadvantages, which to some extent are mirror images of each other. The real world consists of a diversity of institutions for controlling the use of resources. These institutions lie on a spectrum between those that rely solely on governance to those that rely solely on exclusion. ${ }^{65}$ Yet for analytical purposes, it is useful to consider the unique features of the pure types. We consider first some of the advantages and disadvantages of in rem exclusion rights, and then turn to in personam governance rights.

1. The Advantages and Disadvantages of In Rem Rights of Exclusion. - In rem rights of exclusion-classic property rights-perform a number of useful social functions. For example, they provide a basis for security of expectation regarding the use of resources over time; 66 they permit flexible adjustments in the use of resources over time; they provide a baseline against which parties can establish contracts that specify particular uses of resources; and they establish the identity of the "residual claimant" to the attributes of a resource. ${ }^{67}$ We do not question the importance of these

63. See James M. Acheson, Variations in Traditional Inshore Fishing Rights in Maine Lobstering Communities, in North Atlantic Maritime Cultures: Anthropological Essays on Changing Adaptations 253, 262 (Raoul Anderson ed., 1979).

64. See, e.g., Robert Sugden, The Economics of Rights, Co-operation and Welfare 153-55 (1986) (using game theory to develop Humean account of conventional rights of possession).

65. Smith, Two Dimensions, supra note 54, passim.

66. For some modern commentary on this point, see Richard A. Posner, Economic Analysis of Law 36 (5th ed. 1998); Richard A. Epstein, A Clear View of the Cathedral: The Dominance of Property Rules, 106 Yale L.J. 2091, 2093-94 (1997); Carol M. Rose, Canons of Property Talk, or, Blackstone's Anxiety, 108 Yale L.J. 601, 626 (1998) (describing utilitarian argument based in part on security that promotes planning, investment, and trading). For some earlier writings supporting this view, which can be traced back at least as far as the utilitarians and their precursors, see Jeremy Bentham, Theory of Legislation 110-13 (C.K. Ogden ed., 1931) (arguing that "the principle of security ... requires that events, so far as they depend upon laws, should conform to the expectations which law itself has created"); 2 William Blackstone, Commentaries *7 (1766); David Hume, A Treatise of Human Nature 485-89, 502-07 (P.H. Nidditch ed., 1978) (1739-40) ("[E]veryone knows what he may safely possess ....").

67. Residual claims are the value associated with a resource (positive or negative) that remains after all contractual claims associated with the resource have been satisfied. See Eugene F. Fama \& Michael C. Jensen, Agency Problems and Residual Claims, 26 J.L. \& Econ. 327, 328 (1983) (defining residual claims); see also Barzel, Economic Analysis, supra note 7 , at 3 (developing property rights theory based on notion of residual claimancy). 
(and other) traditional justifications of property rights. But none of the foregoing justifications is unique to in rem rights. Each of these functions is also performed, at least some of the time, by in personam rights.

Consider, for example, employment contracts-an obvious type of in personam or paucital right. ${ }^{68}$ Depending on how they are drafted, employment contracts can create a basis for security of expectation in future employment, provide for flexible adjustments in the employment relationship over time, establish a baseline for future contractual modifications of the parties' respective rights, and help identify residual claimants in the employment setting. Thus, in rem rights are not strictly necessary in order to fulfill the traditional functions of property emphasized in the literature on property rights. ${ }^{69}$

The unique advantage of in rem rights-the strategy of exclusion-is that they conserve on information costs relative to in personam rights in situations where the number of potential claimants to resources is large, and the resource in question can be defined at relatively low cost. In the world of Robinson Crusoe, where the only relevant actors are Crusoe and Friday, there will be no occasion to create in rem rights of exclusion. All resources can be divided between Crusoe and Friday by in personam agreement. But as societies become more complex, with increasing numbers of persons and resources, rules of exclusion quickly become the more cost effective strategy for determining use rights. The simple reason is that the information costs of fixing all use rights to resources by in personam contract (or by other governance strategies such as government regulation) would be prohibitive.

Consider the hypothetical world in which $\mathrm{A}$ has in personam use rights in a resource and $\mathrm{B}$ must expend $\$ \mathrm{X}$ in order to gather and process information about A's rights. ${ }^{70}$ If the society grows to the point where

68. There are, of course, collective bargaining agreements, but these would be classified under our schema as compound-paucital rights rather than any type of in rem right. Although the number of parties on one side of the relationship is very large, and each individual has a relatively small stake in understanding the terms governing the relationship, each of the parties to the agreement is individually identifiable.

69. In particular, although in rem exclusion rights often supply a baseline against which contracting takes place, in rem rights are not a necessary condition of establishing in personam contracts. One could establish the baseline for contracting by specifying bundles of use rights over resources, in effect collectively imposing a governance rule, which would then be subject to contractual modification. In fact, this seems to be the way modern economists, beginning with Coase, seem to imagine the system of property rights operating. See Ronald Coase, The Problem of Social Cost, 3 J. L. \& Econ. 1, 27, 37-38 (1960) (implicitly defining the initial "delimitation of legal rights" in terms of use rights).

70. The $\$ \mathrm{X}$ can be regarded as the average cost of additional rights in this world. Whether marginal costs would be increasing, flat, or decreasing would depend on several factors. These include any commonalties among rights that emerged spontaneously (assuming an absence of a numerus clausus, as described in supra note 11), any certification or insurance mechanisms such as those described in infra note 71 , and the extra burdens on processing capacity with greater numbers of things to process. The first two factors would lead to declining marginal costs and the third would lead to increasing marginal 
there are $1000 \mathrm{Bs}$, and each B is similarly bound to respect A's rights, this means it will now be necessary to expend $\$ 1000 \mathrm{X}$ on gathering and processing information about A's rights by all Bs combined. ${ }^{71}$ When we add in the fact that each $\mathrm{B}$ also has her own rights to resources, which must be processed by A and all the other Bs, then the magnification of information gathering and processing costs is multiplied many times over-it is in effect $\$ 1,001,000 X .{ }^{72}$ Clearly, the in personam strategy for determining use rights will rapidly break down in the face of even relatively modest numbers of persons with interlocking interests in the use of scarce resources.

The solution in any moderately complex society to the informationcost problem presented by the need to allocate use rights to resources is to switch to the rem exclusion strategy. In rem rights offer standardized packages of negative duties of abstention that apply automatically to all persons in the society when they encounter resources that are marked in the conventional manner as being "owned." Information is conserved by making these duties apply automatically to delineated resources without regard to the identity of the owner; by making the duties uniform; by restricting the duties to a short list of negative obligations, easily defined and understood by all; and by marking boundaries using easily observed proxies. Large numbers of people still must process information about resources. But the unit costs of processing the information are now much lower- $\$ \alpha \mathrm{X}$ instead of $\$ \mathrm{X}$, with $0<\alpha<1$-so that the total cost of allocating use rights in the society $(\$ 1,001,000 \mathrm{X} \alpha)$ is much lower than it would be if all use rights had to be established individually $(\$ 1,001,000 \mathrm{X})$.

David Hume and other philosophers have obliquely recognized this point by observing that a system of property rights represents a kind of general convention that permits the coordination of social and economic

costs. The point here is that in rem rights involve widespread information costs, which increase with greater idiosyncrasy of the rights in question.

71. One solution might be for the Bs to pool their efforts, and develop some collective means of identifying rights that would reduce the costs to something less than $\mathrm{X}$ for each dutyholder. But when a large number $n$ of dutyholders is involved, each of whom is potentially affected by a right, we are likely to encounter a collective action problem in devising these sorts of collective mechanisms. Even if the collective action problems can be overcome and some cost-saving device is established, as long as the remaining proportion of cost to each of the $n$ dutyholders (Bs) is positive and exceeds the reciprocal of the number of dutyholders $(1 / n)$, then imposing the duty on large numbers of persons will entail larger aggregate information costs than if there is only one dutyholder.

72. Here there are 1001 members of the society (A and the $1000 \mathrm{Bs}$ ), each of whom imposes a total of $\$ 1000 \mathrm{X}$ in processing costs for a total of $1001 \times \$ 1000 \mathrm{X}$ or $\$ 1,001,000 \mathrm{X}$ in processing costs. For an analogous point about the transaction cost savings from having real covenants imposerd by a single real estate developer rather than by bilateral contracts among all affected parties, see Richard A. Epstein, Covenants and Constitutions, 73 Cornell L. Rev. 906, 914-16 (1988). 
activity. ${ }^{73}$ Exclusion rules represent a simple and universal "organizing idea" ${ }^{4}$ that allows a multitude of individuals with a small amount of information to interact in mutually beneficial ways that would be impossible in a world that had only governance rules. Jeremy Waldron has made the point in a particularly trenchant fashion, observing that in a world that lacked such an organizing idea

citizens would have great difficulty following the rules. Everyone would need to become a legal expert to determine at any point what he could or could not do in relation to the resources that he comes across. He would have to acquire a detailed knowledge of the rules for each resource and of his rights, powers, liberties, and duties in relation to it. There would be no other way of ensuring, in ordinary life, that one abided by the rules except to find out what they were and learn them by heart. ${ }^{75}$

In other words, exclusion rules, and in particular in rem legal rights, are a critical part of the "social glue" that allows any group of individuals of any size and complexity to function on a day-to-day basis. ${ }^{76}$

The disadvantages of the exclusion strategy are largely a function of the limitations on such rights imposed by the need to minimize the unit costs of processing information. In order to keep these costs low, it is simply not possible to make these duties very complex or detailed. In rem rights can only work if they are highly standardized and rely on relatively crude proxies to identify the resources that are subject to such rights. This standardization, in turn, greatly limits the degree to which exclusion rules can be used to dictate more fine-tuned and individualized uses of resources. Any time we want to go beyond crude proxies that allocate discretion to owners over large bundles of rights, it will be necessary to shift to a different strategy.

Another way to view the matter is to observe that every in rem right imposes external information costs on a large and indefinite class, without this externality being impounded into the price of the package of rights governing the resource. Because of the potential third-party information costs associated with the creation of novel in rem rights, ${ }^{77}$ all

73. See Hume, supra note 66, at 490; see also Penner, Idea of Property, supra note 44, at 30 (positing that "[n] orms in rem establish the general, impersonal practices upon which modern societies largely depend”); Sugden, supra note 64, at 87-97 (emphasizing the importance of coordination of social activity through property rights).

74. See Waldron, supra note 58 , at $42-43$.

75. Id. Of course, if rules were as complicated as they are in Waldron's example, one alternative to learning and following all rules might be ignoring them, which would defeat the very objective of having a system of rights.

76. Bruce Ackerman has made a similar point. Bruce A. Ackerman, Private Property and the Constitution 116 (1977) (stating that "most of the time Layman negotiates his way through the complex web of property relationships that structures his social universe without even perceiving a need for expert guidance").

77. To illustrate, suppose A transfers Blackacre to B but in so doing attempts to create a new type of in rem right: A reserves an easement in Blackacre for the public to travel 
modern legal systems have been very reluctant to permit new types of in rem rights over resources to be established. ${ }^{78}$ To prevent the creation of these kinds of external information costs, in rem rights are everywhere limited to a small number of standardized types.

Standardization is probably also necessary if in rem rights are to be widely obeyed. As Hume and his successors have observed, much of the protection that property owners enjoy comes from a general respect for property rights and from the fact that third parties informally monitor and help to enforce such rights. ${ }^{79}$ For this informal type of enforcement to occur, it is also necessary that people have a basic notion of what rights exist. This too points to the need for in rem rights to be defined by crude proxies that are readily capable of being understood by all and to the corresponding need to sacrifice some of the benefits of customization of these rights.

Closely related but distinct from the question of the need for standardization is the issue of who supplies these standards. Here too, it seems that the more diffuse and unspecified the relevant third parties are, the more likely it is that some form of governmentally imposed standards will be needed. ${ }^{80}$ Even if we view in rem rights as being social conventions,

over the parcel unless the traveler is wearing an orange coat; orange-coat-wearing people found on Blackacre will be treated as trespassers. This might not seem to expand the scope of the rights of $\mathrm{A}$ and $\mathrm{B}$, but it does mean that the public must do a lot of inquiring before following a large crowd onto an apparently public easement. Note that A and B could perhaps achieve the same result by agreeing that $\mathrm{B}$ would post notices granting permission to all to enter Blackacre except those wearing orange coats. But this would be an in personam licensing agreement-a promise by $\mathbf{B}$ to adopt a certain type of license permitting access to Blackacre. The license would last only as long as B continued to perform his in personam obligation toward A, and would not "run" with the property. The hypothesized property right, in contrast, would last potentially forever and would restrict the rights of the public no matter what actions B decided to take by way of posting notice.

78. Merrill \& Smith, supra note 9, at 3-4; see also, e.g., Jürgen Kohler, The Law of Rights in Rem, in Introduction to German Law 227, 230 (Werner F. Ebke \& Matthew W. Finkin eds., 1996).

79. Eric Posner makes this point in the context of marriage. Restricting the form of marriages facilitates third-party enforcement by making the formal marriage institution focal. Eric A. Posner, Law and Social Norms 79 (2000). As Posner points out, "[t]he problem is that the existence of multiple or idiosyncratic relationships might be so confusing to the members of the community that community enforcement becomes impossible." Id. The norm of possession has been analyzed as a focal point in a game of chicken. Id. at 45, 178-79; Sugden, supra note 64, at 53-103. To this we might add that enforcement of property norms by the third parties in the community becomes much easier when easy conventions like possession and the limited possessory estates facilitate such enforcement.

80. Cf. R.H. Coase, Essays on Economics and Economists 12 (1994) (noting that even stock and produce exchanges regulate activities of traders in great detail in order to facilitate exchange in what amounts to a private law and that "[o]f course, when trading takes place outside exchanges (and this is almost all trading) and where the dealers are scattered in space and have very divergent interests, as in retailing and wholesaling, such a private law would be difficult to establish and their activities will be regulated by the laws of the state"); R.H. Coase, The Firm, the Market, and the Law 10 (1988) [hereinafter Coase, 
the government may have an advantage in setting up focal points in order for parties desiring conventions to attain them more quickly and cheaply. ${ }^{81}$ When standardization must be supplied by the government, there are associated disadvantages, such as reduced opportunities for individual experimentation and the potential collective-choice pathologies associated with efforts to influence government action. Nevertheless, where the government has an advantage in securing the benefits of standardization, we expect a tendency toward some sort of standard forms in the law.

2. The Advantages and Disadvantages of In Personam Governance. - The alternative to a regime of exclusion rules is a regime of governance rules. Governance rules differ from exclusion rules in that they assign particular use rights and duties to particular persons. The principal advantage of governance rules is that they allow society to control resources in nonstandard ways that entail greater precision or complexity in delineating use rights than is possible using exclusion. Allowing in rem property rights to be supplemented by in personam contract rights, in particular, introduces an enormously larger set of options for the use and control of resources than would be possible using exclusion alone. ${ }^{82}$ Permitting resource uses to be regulated by contract also permits a degree of innovation in developing governance structures better suited to individual needs and aspirations than would ever be possible using exclusion rights alone. Persons who have standardized in rem exclusion rights can supplement these rights with a variety of voluntary governance structures, including structures that impose affirmative obligations of performance rather than merely negative duties of abstention. This added flexibility substantially reduces the frustration costs that would result if parties were limited to the few standardized forms permitted by a system of in rem. rights.

These private, use-governance regimes for the control of resources have another advantage: Although they impose intensive informational demands on the contracting parties, they do not as a rule generate significant informational demands on third parties. Such tailored use-governance regimes thus can act as a supplement to the legally mandated system

The Firm] (also noting rules established by commodity exchanges and the need for state regulation in diffuse markets).

81. See Merrill \& Smith, supra note 9 , at $47 \&$ n.169. For a general discussion of the role of law in facilitating the emergence of focal points, see Richard H. McAdams, A Focal Point Theory of Expressive Law, 86 Va. L. Rev. 1649, 1650-54 (2000).

82. Despite other differences, contracts and public regulation may be used to refine a property regime in order to govern specific uses in a more detailed way. On three alternative arrangements for contracting over externalities, see Cheung, Structure, supra note 7, at 64 . Cheung's three-way classification (property, contract, regulation) has been extended and used to explain the evolution of pollution-control regimes. See Carol M. Rose, Rethinking Environmental Controls: Management Strategies for Common Resources, 1991 Duke L.J. 1, 9-36; see also Thomas W. Merrill, Explaining Market Mechanisms, 2000 U. Ill. L. Rev. 275, 278-80 (2000) (discussing Rose's adaptation). 
of forms associated with exclusion rules, but without creating the large external information costs that would be associated with creating more tailored in rem rights.

Governance rules also have unique advantages when we deal with resources that are difficult to package into easily measured and monitored parcels such as are required for exclusion strategies to work. Land and tangible objects can be marked with boundaries, which are visible to others and can be monitored for violations. ${ }^{83}$ But other types of resources, such as ocean fisheries, submerged oil, clean air, and ideas, are much more difficult to divide into parcels. ${ }^{84}$ All else being equal, we are more likely to see restrictions on types of use-governance mechanisms-in seeking to control externalities associated with these difficultto-define resources.

The disadvantages of governance rules more or less track the advantages of exclusion, summarized earlier. As the number of individuals whose actions could potentially impact the resource increases, it will be more costly to specify individual behavior according to a governance strategy: The information costs of specifying which individuals have the right to do what will simply become too great. Accordingly, as the number of affected persons increases, we expect the content of rights over the resource to move in the direction of exclusion, with a designated gatekeeper. ${ }^{85}$ The result will commonly take the form of an in rem right.

The conclusion we draw from this discussion is that systems of in rem and in personam rights entail distinctive advantages and disadvantages associated with the exclusion or governance strategies of which they are

83. See, e.g., Ellickson, Property in Land, supra note 62, at 1329; cf. Waldron, supra note 58, at 37-39 (discussing material resources as central case and noting association of resource with decisionmaker as basis for property).

84. Often what we find is a commons in which a group excludes the "rest of the world" and devises and enforces governance rules that apply to members of the group. See, e.g., Bonnie J. McCay \& James M. Acheson, Human Ecology of the Commons, in The Question of the Commons: The Culture and Ecology of Communal Resources 1, 12-14 (Bonnie J. McCay \& James M. Acheson eds., 1987) (noting that territoriality-the keeping out of nonmembers-is a prerequisite for rules to control use by members, and providing examples of this phenomenon in fisheries); see also, e.g., Ostrom, supra note 61, at 58-102 (analyzing various successful, long-term "common pool resources" communities and identifying similarities among them); Dean Lueck, The Rule of First Possession and the Design of the Law, 38 J.L. \& Econ. 393, 407-09 (1995) (showing how customary rules evolve in communal land relationships which restrict members' use and encourage homogeneity of group members); Rose, The Comedy of the Commons, supra note 61 , at 742-44 (citing examples from nineteenth-century Britain and the United States in noting that customary rights vest property rights in groups that are indefinite and informal, yet are nevertheless capable of self-management); Henry E. Smith, Semicommon Property Rights and Scattering in the Open Fields, 29 J. Legal Stud. 131, 161-69 (2000) (examining the medieval open-field system, in which peasants owned strips of land but used the land collectively for grazing, and identifying manipulating of boundaries and monitoring of norm compliance as substitute methods of abating strategic behavior in the "semicommons").

85. Smith, Two Dimensions, supra note 54 , at $41-42$. 
subsets. In particular, each system of rights entails different patterns of information costs, and hence will be used in different circumstances. Where they are used will be a function of their respective advantages and disadvantages. If rights were costless to delineate and enforce, any structure of rights would do, and there would be no need for a distinction between in personam and in rem rights. ${ }^{86}$ But because the delineation and enforcement of rights is costly, the legal system has found it useful to deploy two different but complementary modalities of rights.

\section{B. The Legal Rules Expected with Different Modalities of Rights}

Given the different information costs associated with in personam and in rem rights, we are now in a position to suggest in general terms how we would expect the legal doctrine associated with these modalities of rights to differ. In this section, we will first consider as a matter of general theory the legal doctrines likely to be associated with in rem and in personam regimes; we then turn to a discussion of the doctrines that are likely to arise in intermediate situations.

1. In Personam and In Rem Regimes. - As noted in Part I.B, the key variables in distinguishing in rem from in personam rights are (1) whether the number of dutyholders is small or large and whether their identity is definite or indefinite; (2) whether the right attaches directly to persons or to persons only through their ownership of a thing; (3) whether those who hold duties simultaneously hold duties to other numerous and indefinite holders of rights; and (4) whether the right is a negative duty of abstention. ${ }^{87}$ The first of these variables, concerning numbers and definiteness, is a matter of degree. Other variables, such as whether the duty attaches to persons directly or only through things, will generate different degrees of complexity insofar as different resources present different definitional problems. Thus, in the real world we would expect to find a spectrum of legal rights, ranging from pure in personam contract law to pure in rem property, with various way stations in between. To facilitate exposition and informal empirical analysis, however, we will proceed as if these variables define distinctive categories.

In personam rights clearly entail greater information-gathering and processing costs than do in rem rights, at least on a unit cost basis. ${ }^{88}$ To create an in personam right, it is necessary to specify right-duty relation-

86. See id. at 52. That governance and exclusion would be interchangeable in a world of zero institution costs is analogous to the point that in such a world all market transactions could be undertaken in one giant firm, and vice versa. See Ronald H. Coase, The Nature of the Firm, 4 Economica (N.S.) 386 (1937), reprinted in Coase, The Firm, supra note 80 , at $37-46$. Cheung makes a related point that in a zero-transaction-cost world there would be no need for a market or property rights. See Steven N.S. Cheung, The Transaction Costs Paradigm, 36 Econ. Inquiry 514, 518-20 (1998).

87. See supra Part I.B.

88. That is, the total information costs required to implement an in personam right divided by the number of parties bound by the right-duty relationship is relatively high compared to in rem rights. See supra notes 68-72 and accompanying text. 
ships with respect to particular uses of resources and to assign these rights and duties to particular persons. The "deal" that the parties must articulate in specifying these rights and duties is thus relatively elaborate. Identifying the affected persons, defining the permitted uses, understanding those definitions, and monitoring for compliance all entail the expenditure of resources.

On the other hand, in personam rights typically entail few external costs for third parties. In most cases the information costs associated with in personam rights will be limited to those incurred by the parties themselves. Since third parties are ordinarily not bound by the rights and obligations created, they ordinarily will not need to acquire information to understand those rights and obligations. ${ }^{89}$

Given the high value associated with flexibility in prescribing particular use rights, and the absence of third-party effects, we would expect the law to encourage customization of in personam rights in order to maximize the value of these reciprocal obligations to the parties. This leads us to expect that the primary means of conserving on the need to acquire information in making and enforcing contracts would be through the adoption of off-the-rack "default rules." These are outcomes that the law specifies as governing the relationship absent a contrary agreement by the parties. ${ }^{90}$ Thus, the parties need not foresee every eventuality, nor need they negotiate rules where they see no need to modify the default. Nor need they acquire information if they know that the default will not surprise them with an unseen trap; knowledge that there is a system of defaults can obviate a great deal of precaution. In truly in personam situations where information is costly and there are no special problems such as bilateral monopoly, the background rules need only be defaults of one sort or another rather than immutable rules. The parties to the in personam relation can either adopt the law's defaults, or if they wish, substitute a provision more suited to their particular circumstances.

We would expect a major class of these defaults to be "majoritarian," meaning that they seek to identify the rule that most parties would prefer to adopt to govern their relationship, if they could costlessly negotiate on the subject. ${ }^{91}$ Some defaults may be penalty defaults, which seek to force an informationally advantaged party to contract around the default and

89. The fact that parties are not bound by these rights does not mean that they will never gather any information on these rights. Competitors, customers, or others who interact with the parties may gather information on rights which affect them but do not bind them.

90. See supra note 10 and sources cited therein.

91. The issue is more complicated than simply counting up the preferences of contracting parties, since this ignores the disparate costs of contracting around or of failing to contract around default rules. See Ian Ayres \& Robert Gertner, Majoritarian vs. Minoritarian Defaults, 51 Stan. L. Rev. 1591, 1600 (1999); David Charny, Hypothetical Bargains: The Normative Structure of Contract Interpretation, 89 Mich. L. Rev. 1815, 1849 (1991). We do not address this complication here. 
thereby reveal information to the informationally disadvantaged party. ${ }^{92}$ Even if contracting on the issue does not occur, the uninformed party will enjoy the benefit of the default and so will have less incentive to make costly inquires to avoid potential pitfalls. In a few circumstances involving in personam relations, the law will adopt immutable rules, particularly in the areas of fraud, duress, unconscionability, and the nature of the contracting process itself, often in order to assure that the rights and obligations are truly consensual. ${ }^{93}$ General knowledge of the existence of such a system of default and immutable rules (rather than its details) will conserve on information gathering: A rationally ignorant party will need to make fewer inquiries to avoid traps.

We would also expect to observe significant variation in default rules both over time and from one legal context to another. This again follows from the importance attached to flexibility where in personam obligations are chosen and from the general absence of third-party effects. As the nature of economic activity evolves and the assessment of the costs and benefits of particular activities changes, we would expect to see changes in majoritarian and penalty default rules. Similarly, there is no reason why we would expect to find the same default rules in different areas of economic activity. What makes sense for employment contracts may not make sense for construction contracts, and vice versa. Thus, we would predict that majoritarian and penalty defaults will differ from one area of in personam obligation to another. ${ }^{94}$ The principal question for the legal system will be identifying the point at which the fine-tuning of defaults ceases to be cost effective.

This complex and mutating menu of default rules is made possible by the fact that these rules will be of primary concern only to the contracting parties. Since such rules typically will not impose large informational costs on third parties, the law is free to indulge in a larger variety of rules and in changes in rules over time. This is especially true in private dispute resolution between members of an industry. Thus, for example, the diamond industry can adopt rules for the private adjudication of disputes that are unique to the industry, without imposing significant costs on those who contract in other industries. ${ }^{95}$ The costs of processing in-

92. Ayres \& Gertner, Filling Gaps, supra note 10, at 112-15.

93. See supra note 10 and sources cited therein.

94. Both majoritarian and penalty defaults can be said to seek to maximize value of the in personam relation - taking into account the parties' ability to economize on inquiry costs-in situations where the design (and possibly the application) of the default requires detailed knowledge of the characteristics of the other party, what information they possess, or other information. See Ian Ayres \& Robert Gertner, Strategic Contractual Inefficiency and the Optimal Choice of Legal Rules, 101 Yale L.J. 729, 765-66 (1992) [hereinafter Ayres \& Gertner, Contractual Inefficiency]; Schwartz, Default Rule, supra note 10, at 390-98 (arguing that many "problem-solving" default rules make excessive informational demands on officials).

95. Lisa Bernstein, Opting Out of the Legal System: Extralegal Contractual Relations in the Diamond Industry, $21 \mathrm{~J}$. Legal Stud. 115, 115 (1992) (indicating that " $[t]$ he 
formation about industry-specific default rules will be largely confined to the parties themselves, greatly reducing the potential for confusion that would likely arise if a large and indefinite class of dutyholders had to process information about a variegated menu of default rules.

In rem rights entail lower information costs, at least on a unit-cost basis. To create an in rem right it is necessary only to specify particular resources and to identify one person as the manager (owner) of the resources. The "deal" here is much simpler. It confers general exclusionary rights on the owner and then leaves it to the owner's discretion to establish use rights. To be sure, the resource itself must be defined, this definition must be understood by a large and indefinite class of dutyholders, and there will be monitoring for compliance. But the legal specification of the right stops with the identification of the resource and a few simple rights of exclusion. The legal rules do not concern themselves with use rights or identification of persons entitled to engage in particular uses. In these respects, in rem rights conserve on information gathering and processing costs.

Nevertheless, because in rem rights impinge upon a very large and open-ended class of third persons, the legal rules must be designed so as to minimize the information-cost burden imposed on a great many persons beyond those who are responsible for setting up the right. This suggests that standardized rights will be strongly encouraged, since a proliferation of forms will magnify the information costs to the third parties who must respect the rights so created. A system of in rem rights will thus generally require that the parties adopt one of a small number of standard forms that define the legal dimensions of their relationship. ${ }^{96}$ And the substantive rights and duties associated with in rem rights will typically be immutable, meaning that they are not subject to revision by agreement.

The fact that the identity of the dutyholders is indefinite also magnifies the information costs. Where in personam rights are concerned, the identities of the parties who have rights and duties are specified when the right is created. This means that the person establishing the right can investigate the dutyholder, draw upon past experience, reputation evidence, or other factors, before determining whether to impose a duty of performance. In contrast, holders of in rem rights do not know the identity of the dutyholders ex ante. As a result, the attributes of those persons who will come into contact with and may potentially violate the right are also unknown. This helps explain why in rem rights are always simple duties of abstention. The quality of performance of positive duties de-

diamond industry has systematically rejected state-created law," and instead has "developed an elaborate, internal set of rules, complete with distinctive institutions and sanctions, to handle disputes among industry members").

96. This is the numerus clausus principle described in supra note 11. See also Merrill \& Smith, supra note 9 , at 3-4. 
pends critically on the attributes of the individual performing such obligations, making it inappropriate to cast such a duty on the world at large.

Because in rem rights are binding on an indefinite class of persons, the rules must communicate information about the scope of protected rights to this large universe of interests at acceptable costs. This means that substantive legal norms associated with in rem rights are more likely to be expressed as rules that turn on one or a small number of publicly observable states of fact, and thus are formalistic or bright-line in character. The common law rule that the person in possession of a resource is presumed to have a property right is one example. ${ }^{97}$ The rule of strict liability for intentional or continuing trespass to land as defined by the $a d$ coelum maxim is another. ${ }^{98}$

2. Intermediate Situations. - We can also offer some general predictions about intermediate situations that partake of some features of in personam and some features of in rem rights. As noted in Part I, we can isolate two types of intermediate situations: compound-paucital (in which rights avail against numerous identified persons) and quasi-multital (in which rights avail against singular, unidentified persons). In reality, intermediate situations will vary along both dimensions (definiteness and numerosity), and thus will reflect various way stations along a continuum between the pure in personam and pure in rem modalities of rights. De-

97. See, e.g., Russell v. Hill, 34 S.E. 640, 640 (N.C. 1899) (“[A]s possession is the strongest evidence of the ownership, property may be presumed from possession."). Commentators have noted that the concept of possession, which is critical both in establishing rights to unowned resources and as a proxy for ownership in everyday life, is defined in terms of acts that are likely to provide clear notice to the world of a unique claim to a resource. Richard A. Epstein, Possession as the Root of Title, $13 \mathrm{Ga}$. L. Rev. 1221, 1222-23 (1979) (arguing that because of courts' modest remedial powers their "definition of rights is therefore apt to be made along certain 'natural lines'; there will be broad general propositions that can apply to all against all, and there will be no reference to the numbers or formulas . . . that can be generated by direct administrative controls, such as zoning"); Carol M. Rose, Possession as the Origin of Property, 52 U. Chi. L. Rev. 73,88 (1985) (concluding that the standards for determining possession are based on "a specific vocabulary within a structure of symbols approved and understood by a commercial people").

98. The full statement of the maxim is cujus est solum, ejus est usque ad coelum et ad inferos (he who owns the soil owns also to the sky and to the depths). The maxim is routinely followed in resolving issues about ownership of air rights, building encroachments, overhanging trees limbs, mineral rights, and so forth. See, e.g., Harding v. Bethesda Reg'l Cancer Treatment Ctr., 551 So. 2d 299, 302 (Ala. 1989) (finding that under ad coelum rule surface owner has the right to remove overhanging tree limbs and intruding tree roots); Peters v. Archambault, 278 N.E.2d 729, 730 (Mass. 1972) (holding that surface owner has right to mandatory injunction against building encroachment); Edwards v. Sims, 24 S.W.2d 619, 620 (Ky. 1929) (stating that under ad coelum rule owner of surface can control access to cave immediately below the land). Certain exceptions to the maxim have been recognized, for example an exception for airplane overflights. See Brown v. United States, 73 F.3d 1100, 1103-04 (Fed. Cir. 1996); Thomas W. Merrill, Trespass, Nuisance, and the Costs of Determining Property Rights, 14 J. Legal Stud. 13, 35-36 (1985). But for work-a-day issues about what is included in the ownership of land, the maxim is assumed by all to be the governing rule. 
tails of resource governance must be processed by (or about) either a large or indefinite class of dutyholders in these intermediate situations. As such, they present more widespread information costs than do in personam rights and may call for intervention by the law that goes beyond that seen in the in personam case. Still, the informational burden is less than in the case of in rem rights. Thus, legal intervention is likely not to require the same strong standardization and heavy use of immutable rules characteristic of the in rem modality.

In both what we have called the compound-paucital situation and the quasi-multital situation, the parties are likely to have incomplete information, and one party may be at an especial informational disadvantage, yet the problem is not likely to be severe enough to warrant full mandatory standardization of the numerus clausus variety. In both our stylized intermediate situations, those parties who do overcome the informational deficiency can do so in ways that do not impose costs on third parties generally. Thus, we expect an intermediate level of intervention in intermediate situations. This intervention will reflect the nature of the informational problem.

In the compound-paucital case, where the identity of the parties is definite but there are numerous parties on one side of the relationship, two types of information problem are likely to arise. First, many of the exact characteristics of the numerous parties on one side of the relationship cannot be cost effectively known. This presents a problem for the single party who, just as in an in personam situation, wants information about the group as a whole in order to negotiate a contract that accounts for those characteristics. The situation is in this respect little different from the incentive to investigate one's contractual partner in ordinary in personam relations. Second, the numerous parties individually may be rationally ignorant about aspects of the contract, to a greater extent than the singular party. ${ }^{99}$ The singular entity on the one side of the transaction has a large amount at stake, equal to the individual benefit from each transaction times the total number of parties on the other side. But each member of the class of definite but numerous parties on the other side has only his or her individual transaction at stake, which is certainly small in absolute value relative to the amount that the singular entity has at stake. This asymmetry may create opportunities for the singular entity

99. Numerosity can affect either the right-side or the duty-side of the equation. The numerous participants in a lottery or raffle can be said to have distinct individual rights against the sponsor of the contest; this is a case of numerous but individual rightholders and a single dutyholder. An automobile manufacturer who provides financing to numerous sellers illustrates the situation where there is a single rightholder and numerous but individually identifiable dutyholders. In some circumstances, e.g., the provision of financing for the sale of a product subject to a warranty, a single entity will have both rights and duties against a large number of definite but similarly situated individuals. 
to exploit its superior information about the terms and conditions of the obligation to the detriment of the class. ${ }^{100}$

In the quasi-multital situation, where the number of parties is small but the identity of one of the affected parties is indefinite, a lack of information about the indefinite party is likely to be a problem. Such situations usually arise when one of the original contacting parties, A or B, transfers all or part of his or her interest to a third party, C. ${ }^{101}$ Because it is foreseeable that this may happen, A and B can, in theory, anticipate the problem and negotiate appropriate provisions to protect against it. But because the identity of $\mathrm{C}$ is indefinite, it is difficult to foresee exactly what issues will arise and what contingencies must be protected against. If appropriate contractual provisions are not adopted to handle the contingencies that arise, A or B will have to fall back on either their general in rem rights vis-à-vis $\mathrm{C}$, or on whatever special default rules the law adopts for dealing with these situations.

What sort of legal doctrine would we expect to find in these intermediate situations? Stated in its most general form, the problem is that as rights take on more in rem features-increased numerosity and indefiniteness-informational demands become greater. Short of requiring standardization to remove the extra information-processing load, the law can adopt one of two strategies: It can either facilitate the generation of information-the notice strategy — or it can impose a rule that favors the uninformed party in order to reduce that party's need for information gathering-the protection strategy.

The notice strategy entails the disclosure of new information about one or more discrete attributes of the parties' relationship. Notice will generally work best where information can be cost effectively produced, but this may not happen because those who have the information do not have sufficient incentive to produce it or disclose it, ${ }^{102}$ or have a strategic incentive to keep the information secret. ${ }^{103}$ In such situations, the law

100. Whether this could in fact occur will depend on the characteristics of the relevant market, including the fraction of those in the position of the numerous parties who comparison shop. See infra note 111 and sources cited therein.

101. For example, where a bailee mistakenly delivers bailed goods to a third party, the third party will incur a duty to return the goods to the bailor, but the identity of the third party would have been unknown to the bailor ex ante.

102. This can happen, for example, because the information has a public or collective good character. Normally, if the potential producer of the information cannot profit from the information or its dissemination, less of it will be produced and disseminated. Jack Hirshleifer \& John G. Riley, The Analytics of Uncertainty and Information 259 (1992) (describing traditional public-goods analysis of information and citing literature); Marcel Kahan \& Michael Klausner, Standardization and Innovation in Corporate Contracting (or "The Economics of Boilerplate"), 83 Va. L. Rev. 713, 729-36 (1997) (explaining possibility that positive externalities conferred on later adopters would leave diminished incentive to innovate in contractual terms).

103. This type of strategic behavior has been thoroughly explored in the literature on penalty default rules; with respect to the issue in question, the penalty default is aimed at the informationally advantaged party who is tempted to inflict a loss on the other party 
can force the production of information either through regulations that mandate disclosure or through penalty default rules. ${ }^{104}$

The protection strategy entails the legal standardization of one or more discrete attributes of the parties' relationship. Protection works best when it is not cost effective to produce the missing information, generally because the individual stakes are too small to warrant the expense of generating or processing the information. Default rules in contract perform such a protection function: Where the law supplies a default that uninformed parties would prefer, one effect is to reduce the need to collect information. ${ }^{105}$ In situations where both parties are rationally uninformed, we typically find majoritarian defaults, that is, defaults that give the parties what they would have agreed to had they contracted over the issue. ${ }^{106}$ Knowing that the law supplies such defaults, the parties can remain rationally ignorant. Alternatively, the uninformed party may be on one side of the transaction only, and here we tend to find informationforcing, penalty-default rules. ${ }^{107}$ Such rules tend to be justified on the ground that they force information, ${ }^{108}$ but they also provide protection. In those situations where the informationally advantaged party does not contract around the default, the uninformed party can rely on the protec-

(and shrink the contractual pie overall) in order to appropriate larger gains for himself. Ayres \& Gertner, Filling Gaps, supra note 10, at 94 (discussing strategic behavior and shareof-pie and size-of-pie effects). Many of the situations discussed in the penalty-default literature are compound-paucital or quasi-multital.

104. Classic examples of penalty default rules are the reasonable-foreseeability rule of Hadley $v$. Baxendale for contract damages, and the zero-quantity default under the Uniform Commercial Code. The Hadley rule can be expected, under certain assumptions, to induce a customer to reveal supranormal damages from the loss of shipped goods. Ayres \& Gertner, Filling Gaps, supra note 10, at 112; Lucian Arye Bebchuk \& Steven Shavell, Information and the Scope of Liability for Breach of Contract: The Rule of Hadley $v$. Baxendale, 7 J.L. Econ. \& Org. 284, 286 (1991). The "zero-quality default" refers to the U.C.C. provision that enforcement of a sales agreement will only occur up to an amount stated, and if parties to a sale do not specify a quantity, then the agreement may be deemed unenforceable. U.C.C. $\$ 2-201(1)$ (1999). This rule can be expected to induce explicitness about quantity for the benefit of courts interpreting contracts for the sale of goods. Ayres \& Gertner, Filling Gaps, supra note 10, at 96-97. In contrast, the U.C.C. provides for a reasonable price default if the parties contract for sale without being explicit as to price. U.C.C. $\S 2-305(1)$.

105. The point is now familiar but for a very early recognition of how default rules are in effect mandatory when parties do not make the effort to contract around them, see Nathan Isaacs, The Standardizing of Contracts, 27 Yale L.J. 34, 38 (1917).

106. Ayres \& Gertner, Filling Gaps, supra note 10, at 94.

107. See id. at 91 .

108. If a penalty default is set against an informationally advantaged party, there may be notice if the informationally advantaged party contracts around the rule. Contrast penalty defaults that are designed to force both parties to reveal information for the benefit of an adjudicator; the default-for example the U.C.C.'s zero-quantity default-is set at a default neither party will want, in order to induce them to reveal the information. Here the situation involves courts as the relevant third parties. See supra note 104 and sources rited therein. 
tion of the default. ${ }^{109}$ Protection can also come about through positive regulation, as in consumer protection laws. Thus, the case for a mandatory warranty is strongest where most consumers would like a warranty, but too few find it worthwhile to inform themselves about available warranties or incur the expense of comparison shopping on this basis; here the regulatory mandate can supply a protective term.

We would further predict compound-paucital relations and quasimultital relations to coincide with one strategy or the other based on the differing characteristics of the uninformed party in each situation. Under either strategy, the legal doctrine in intermediate cases will generally fall short of the mandatory standardization of in rem rights but there will be a tendency towards increased standardization as the numbers or indefiniteness of third parties increases.

We would expect compound-paucital situations to tend in the direction of the protection strategy. This is because the stakes for the numerous parties on one side of the relationship are apt, in most cases, to be too small to justify much processing of information over any but the most salient issues. ${ }^{110}$ Of course, there are a number of solutions to the problem of rational ignorance, many of which do not entail legal intervention, such as the development of tradenames and trademarks that are associated with reputations for honesty and reliability, the rise of informational intermediaries, or simply relying upon sophisticated marginal consumers. ${ }^{111}$ But as a positive matter, we would expect to find that compound-

109. Penalty defaults tend to be "strong" default rules. See, e.g., Ayres \& Gertner, Filling Gaps, supra note 10, at 120-24 (noting spectrum of default rules in contract law with a range of strength according to how explicit one must be to contract around the default); Zamir, supra note 10, at 1738 (describing areas in which defaults are strong). In general, the contract literature speaks of defaults as becoming stronger as they become more difficult to contract around because the law requires more explicit action to do so. "Strength" is a matter of degree with a mandatory rule being the strongest. If parties are not likely to contract around a default, the rule mainly ensures protection for the informationally disadvantaged party. Conversely, if parties are likely to contract around a default (for example, because it is not costly or is very advantageous to do so), then notice is being emphasized.

110. If consumers cannot process great quantities of information, new information may be ignored or may crowd out other information. See, e.g., Richard Craswell, Interpreting Deceptive Advertising, 65 B.U. L. Rev. 657, 690-91 (1985) (noting controversy over information overload theory under which more information can cause recipients to ignore all information, but noting possible crowding out effect of mandatory information).

111. It is not necessary for all of the numerous parties in the compound-paucital situation to inform themselves; some minimum subset will do. For a detailed treatment of the circumstances under which features of contracts like product warranties will or will not be supplied by the market, see Alan Schwartz \& Louis L. Wilde, Imperfect Information in Markets for Contract Terms: The Examples of Warranties and Security Interests, $69 \mathrm{Va}$. L. Rev. 1387, 1401-29 (1983) (proposing that regulatory efforts aim at promoting disclosure of information to consumers and comparison shopping rather than banning of certain contract terms to protect uninformed consumers); see also Richard Craswell, Passing on the Costs of Legal Rules: Efficiency and Distribution in Buyer-Seller Relationships, 43 Stan. L. Rev. 361, 362, 368-85 \& n.35 (1991) (discussing circumstances under which costs 
paucital situations will incline with some frequency toward the protection strategy. ${ }^{112}$

Conversely, we would expect to find that quasi-multital situations tend to be associated with notice strategies. Because it is possible to anticipate third-party transfers by contract, mandatory protection rules are generally inappropriate here. At the same time, because the identity of the third party is indefinite, and the problems that the transferee will present are difficult to anticipate, the rules should be designed to protect the interests of the nontransferring party. Together, these considerations suggest that it will ordinarily make sense for the law to encourage disclosure of information by the transferring party as a way of overcoming informational problems, rather than to impose protective rules. This does not mean, of course, that notice will always be the preferred strategy in quasi-multital situations. There may be circumstances in which the stakes are too low to justify much ex ante contracting over a particular issue, in which case a protection strategy might make more sense here, as it does in the typical compound-paucital situation. We would also expect that, in many cases, the notice strategy will incorporate a protective element, such that a failure to disclose would result in the imposition of a rule favorable to the nontransferring party, as is the case with the typical penalty default rule. ${ }^{113}$ Such a protective rule allows parties to transact without being

of a mandatory rule are passed on and arguing against the intuition that "buyers are more likely to benefit from a rule if sellers are unable to pass along much of their costs"); Duncan Kennedy, Distributive and Paternalist Motives in Contract and Tort Law, $41 \mathrm{Md}$. L. Rev. 563, 614-21 (1982) (discussing inequality of bargaining power); Alan Schwartz \& Louis L. Wilde, Intervening in Markets on the Basis of Imperfect Information: A Legal and Economic Analysis, 127 U. Pa. L. Rev. 630, 646-58 (1979) (employing economics of information models to ascertain which criteria justify market intervention); Henry E. Smith, Ambiguous Quality Changes from Taxes and Legal Rules, 67 U. Chi. L. Rev. 647, 702-15 (2000) (arguing that price movements after the imposition of mandatory contractual terms are ambiguous where quality is variable).

112. Perhaps the classic illustration of a protection strategy imposed by regulation in the compound-paucital situation is provided by the filed-rate doctrine of public utility and common carrier law. See generally Joseph D. Kearney \& Thomas W. Merrill, The Great Transformation of Regulated Industries Law, 98 Colum. L. Rev. 1323, 1330-33 (1998) (analyzing the origins of the filed-rate doctrine in the context of regulated industries law). Under this doctrine, utilities and common carriers must establish their rates and services in standard form contracts called tariffs, which must be made available on equal and nondiscriminatory terms to all customers. Deviations from the filed tariff are not permitted, but the relevant regulatory agency is authorized to review and adjust the terms to ensure that they are "just and reasonable" to affected customers. See AT\&T v. Central Office Tel., Inc., 524 U.S. 214, 221-24 (1998); Maislin Indus., U.S., Inc. v. Primary Steel, Inc., 497 U.S. 116, 130-32 (1990). In effect, the singular provider of services establishes an in personam right which is made available to a numerous class of customers, and the customers (who remain rationally ignorant of the details of the tariff) are then protected from exploitation by the provider through agency oversight.

113. If parties are heterogeneous, the majority rule approach may not result in overall wealth maximization; some contracts will have higher stakes than others and some will be more susceptible to legal intervention than others. 
detained by the need to engage in extensive inquiry in order to avoid nasty surprises about the indefinite identity of the third party.

By breaking down in rem rights into two intermediate cases we can sharpen our expectations about the form that legal intervention will take. It should be remembered, however, that we are dealing with a spectrum from in personam to in rem rights, and we will emphasize how familiar problems of incomplete information are increasingly important as one moves toward the in rem pole of the spectrum.

\section{Institutions Along the Property/Contract Interface}

In this Part, we review several legal institutions that exist along the property/contract interface: bailments, landlord-tenant law, security interests, and trusts. We have identified these institutions by looking to areas of the law that historically have been subject to disputes about whether they are "truly" based on contract or on property. Our assumption is that such debates mean that these institutions partake of features that are both in personam and in rem. ${ }^{114}$ In each of our four areas, we will begin with a brief look at the history and general structure of the institution, and will then review examples of the legal treatment of situations implicating in personam, intermediate, and in rem relations.

Drawing on the discussion in Part II, we can articulate the following hypotheses regarding the structure of legal rules within these test institutions. In terms of independent variables, we seek to identify four prototypical situations within each of these institutions: (1) pure in personam relations, where a single identified person has rights against and is owed duties by another identified person; (2) compound-paucital relations, where a single identified person has rights against or is owed duties by a large number of identified persons; (3) quasi-multital relations, where a single identified person has rights against or is owed a duty by a single person of indefinite identity; and (4) pure in rem relations, where a single person has rights against and is owed duties by a large and indefinite class of persons.

Our dependent variable is the nature of the legal doctrine adopted in any particular situation. Our general hypothesis is that in personam relations will be governed by rules similar to those associated with the law of contract, in rem relations will be governed by rules similar to those associated with the law of property; and intermediate relations will adopt protection strategies and notice strategies designed to overcome intermediate-level informational problems, with greater standardization as the problems take on more of an in rem character. More specifically, we would predict the following:

114. Our list is not exhaustive. For example, we have omitted easements, real covenants, and equitable servitudes, concluding that they are better left for separate treatment at a later date. 
(1) In the in personam situation the legal regime will tend to (a) enforce any express agreement between the parties in accordance with its terms; (b) where no express agreement exists, adopt default rules that, directly or indirectly, plausibly maximize the joint wealth of the parties.

(2) In the compound-paucital situation, the legal regime will tend to adopt contract rules modified by rules designed to redress problems of incomplete information associated with rational ignorance, with the predominant strategy being rules designed to protect numerous parties with incomplete information from exploitation by singular parties armed with better information.

(3) In the quasi-multital situation, the legal regime will tend to adopt contract rules modified by rules designed to address the incomplete information associated with the presence of an indefinite party, with the predominant strategy being rules designed to compel notice of critical information to nontransferring parties with incomplete information.

(4) In the in rem situation, legal regimes will tend to (a) endorse formalistic rules that define resources in easily ascertained ways and that impose negative duties of abstention with respect to these resources that are uniform and easy to understand; (b) treat these rules as immutable, meaning that they are not subject to modification by contract.

These predictions are summarized in Figure 2.

Figure 2. Predicted Legal Rules

\begin{tabular}{|c|c|c|c|}
\hline & & \multicolumn{2}{|c|}{ Numerosity } \\
\hline & & Nonnumerous & Numerous \\
\hline \multirow[t]{2}{*}{ Definiteness } & Definite & $\begin{array}{l}\text { Paucital: Default } \\
\text { Rules }\end{array}$ & $\begin{array}{l}\text { Compound-paucital } \\
\text { Protection Strategy }\end{array}$ \\
\hline & Indefinite & $\begin{array}{l}\text { Quasi-multital: Notice } \\
\text { Strategy }\end{array}$ & $\begin{array}{l}\text { Multital: Immutable } \\
\text { bright-line rules }\end{array}$ \\
\hline
\end{tabular}

We do not expect to find that the legal doctrine of each of our four institutions would correspond exactly to the predicted pattern. But we hypothesize that the degree of correspondence will serve as a test of the power of our underlying theory about information costs and the differences between property and contract rules. If we find little evidence of the predicted pattern, but simply a blend or hash of contract and property principles, then this will tend to suggest that our theory is relatively weak-discernible perhaps in the pure contract and pure property situations from which we have drawn it, but subject to dilution by other forces and considerations we have not identified. If we find the predicted pat- 
tern repeated among all or even several of these institutions, then this will tend to suggest that our theory is more powerful.

Our choice of legal institutions and doctrines for review is, by necessity, selective. Thus, we cannot prove with any certainty that the patterns we detect hold throughout each institution, or would be replicated if other institutions were considered. Nevertheless, we have endeavored to identify four institutions that are widely regarded as falling along the borderline between contract and property, and legal issues within those institutions that arise with some frequency and have been regarded by commentators as being of central importance to each institution.

Also, we readily admit that in many instances it is possible to cite alternative functional explanations for the doctrines we discuss. We do not deny that these explanations may have some validity. We are interested in determining whether the larger pattern of legal doctrine within these borderline institutions either does or does not conform to the information-cost demands associated with the underlying structure of rights. Thus, the fact that some individual doctrines may have additional explanations, and hence may from our perspective be overdetermined, does not necessarily undermine the inquiry we undertake.

\section{A. Bailment}

A bailment is the rightful possession of a thing for a particular purpose by one who is not the owner. ${ }^{115}$ Familiar examples include clothing given to a dry cleaning shop for cleaning, an automobile handed over to a valet for parking, or securities transferred to a broker for sale on an exchange. Bailment clearly falls along the property/contract interface under our criterion of identification. Some commentators, including Blackstone and Story, have maintained that all bailments must be grounded in express or implied contract. ${ }^{116}$ Other commentators, most notably Williston, have noted that bailment duties can arise in situations, such as a finding of lost property, where it is utterly implausible to say that any contract exists. ${ }^{117}$ This leads to the conclusion that bailment should be regarded as a type of property right.

115. See R.H. Helmholz, Bailment Theories and the Liability of Bailees: The Elusive Uniform Standard of Reasonable Care, 41 U. Kan. L. Rev. 97, 97 (1992).

116. See 2 Blackstone, supra note 66 , at $* 452-* 454$ (defining bailment as "a delivery of goods in trust, upon a contract expressed or implied, that the trust shall be faithfully executed on the part of the bailee"); Joseph Story, Commentaries on the Law of Bailments $\S 2$, at 5 (James Schouler ed., 9th ed. 1878) (defining bailment as "a delivery of a thing in trust for some special object or purpose, and upon a contract, express or implied, to conform to the object or purpose of the trust").

117. See 9 Samuel Williston, A Treatise on the Law of Contracts $\S 1030$, at 875 (Walter H.E. Jaeger ed., 3d ed. 1967) (defining bailment as "the rightful possession of goods by one who is not the owner"); see also William King Laidlaw, Principles of Bailment, 16 Cornell L.Q. 286, 287 (1931) ("Although it is frequently said that bailment is founded upon contract, the actual decisions show that it is not so founded."). 
Our objective is not to resolve this definitional dispute. Rather, we are interested in testing the hypothesis that borderline institutions will resemble contract law insofar as the structure of rights is in personam with its narrower informational effects, but will mutate into more property-like forms as the structure of rights becomes in rem, with correspondingly widespread information-cost implications.

All bailments are grounded in some kind of voluntary undertaking by the bailee to take possession of the bailor's property; consequently, the bailee's obligation to the bailor is always in personam in nature. ${ }^{118}$ It is more difficult to see how bailment implicates in rem relations, but they are also present. The bailor transfers possession to the bailee for a particular purpose, but most other attributes of property are retained by the bailor. In other words, most in rem rights associated with the ownership of property-including the right to exclude others, the power to sell the chattel to third parties, the power to transmit the chattel upon death, and so forth-are retained by the bailor. ${ }^{119}$ Both the bailee and the large and indefinite class of persons who make up "the rest of the world" are obligated to respect these retained in rem rights.

Given that these in rem rights are unaffected by the bailment, the institution of bailment creates a pervasive problem of ostensible ownership. ${ }^{120}$ Ordinarily, possession of chattels signifies ownership. ${ }^{121}$ If one drives around in a certain car, or has a certain painting hanging in one's house, third parties will justifiably assume that one owns the car or the painting. Bailees have possession of chattels but do not have ownership rights. Thus, the institution of bailment creates a serious danger of confusion on the part of third parties. One concern is that bailees may take advantage of this confusion to convert the bailor's property. At the very

118. In the case of a bailment for hire, the bailee's duty rests on contract. Gratuitous bailments are those voluntary bailments in which the bailee receives no explicit or implicit consideration, current or prospective. See Kurt Philip Autor, Note, Bailment Liability: Toward a Standard of Reasonable Care, 61 S. Cal. L. Rev. 2117, 2119 n.2 (1988) (spelling out common law definition and citing cases). See generally 8A Am. Jur. 2d Bailments $§ 1$ (1997) (discussing legal possibility of gratuitous bailment). Bailments created by a finding of lost property can be said to rest on the bailee's voluntary undertaking upon assuming possession and control of the lost object. See id. $\S 39$ (discussing nature of bailment in finder cases); Joseph H. Beale, Jr., Gratuitous Undertakings, 5 Harv. L. Rev. 222, 224 (1891) (noting lack of consent by loser of property in finder situation and implying consent by finder); Laidlaw, supra note 117, at 287 (same). In the case of finders, the identity of the owner is indefinite, making this case closer to what we have called quasimultital than in personam.

119. The exception, of course, is the right of use. While all other ownership rights are retained by the bailor, the transfer of possession to the bailee means that in practice the bailor is unable to exercise the right to use for the duration of the bailment. For example, the owner of a book loaned out to another will be unable to exercise the right to use the book while it is in the bailee's hands.

120. On the general problem of ostensible ownership in law, see Richard A. Epstein, Inducement of Breach of Contract as a Problem of Ostensible Ownership, 16 J. Legal Stud. 1, 10-15 (1987) [hereinafter Epstein, Inducement].

121. See supra note 97 . 
least, third parties who have dealings with either bailors or bailees may incur higher information costs if bailees conceal the limits of their authority. For example, persons who are interested in acquiring ownership of similar objects will incur higher information costs if bailees as a class have a tendency to act like owners-more investigation will be required to make sure that persons who purport to be owners are not in fact errant bailees. Although bailment gives rise to a variety of legal issues, we focus here on the most frequently litigated issue-the question of the bailee's responsibility for loss or destruction of the property.

1. In Personam Relations. - The first place to look in determining the bailee's responsibility for loss or destruction is to examine the express or implied undertaking of the bailee. Insofar as the parties have made an express agreement establishing the bailee's duty of care, that agreement will generally be enforced according to its terms. ${ }^{122}$ More significant for our purposes are the rules that apply if the parties have failed to specify the standard of care. Bailment law historically adopted different standards of care depending on the nature of the bailment. Gratuitous bailments for the benefit of the bailor were distinguished from gratuitous bailments for the benefit of the bailee, and both were distinguished from bailments for hire. ${ }^{123}$ Commentators have long urged that these distinctions be eliminated, and replaced with a single uniform standard of care-a duty of reasonable care, or a negligence standard. ${ }^{124}$ At the level of official doctrine, the decisional law appears to have moved far toward embracing this position. ${ }^{125}$

A standard of reasonable care is consistent with what our theory would predict we would find where the structure of the relationship is in personam. General contract law precepts suggest that the law will adopt the standard that the parties would most likely agree upon if they could

122. See Ray Andrews Brown, The Law of Personal Property $\S 11.5$, at 274 (Walter B. Raushenbush ed., 3d ed. 1975) (noting that bailors and bailees are generally free to vary terms of bailee's liability by contract); cf. Charles C. Arensberg, Limitation by Bailees and by Landlords of Liability for Negligent Acts, 51 Dick. L. Rev. 36, 37 (1946) (noting that a bailee under Pennsylvania law may stipulate against his own negligence if stipulation is the "essence of the contract").

123. See Brown, supra note $122, \S 11.1$, at 255-57; Autor, supra note 118 , at 2128-29. Roman law adopted an even more complex six-part classification, which was seemingly endorsed as a matter of common law in Coggs v. Bernard, 2 Ld. Raym. 909, 912-13, 92 Eng. Rep. 107, 108 (K.B. 1703). Brown, supra note 122, § 11.1, at 252-55.

124. See, e.g., Autor, supra note 118, at 2151 (proposing adoption of "the standard of reasonable care as a uniform measure for determining liability" of bailees).

125. See Helmholz, supra note 115 , at 99 . The difference between the old approach (different standards of care for different categories of bailments) and the new approach (a single standard of reasonable care for all bailments) may be more apparent than real. This is because the factors singled out by the old approach-such as whether the bailment was gratuitous or for hire, and whether it was for the benefit of the bailor or the bailee-are circumstances that can be argued to the trier of fact under the new approach in calibrating what constitutes reasonable care under the circumstances. 
costlessly negotiate over the issue. ${ }^{126}$ A standard of reasonable care or negligence presumably encourages an efficient degree of care by the bailee, which in turn maximizes the joint value associated with the bailment. Thus, this standard is plausibly the one the parties would agree upon if they were to negotiate a standard. ${ }^{127}$

Moreover, because the issue arises in an in personam context, it is appropriate that the parties be allowed to modify this standard by contract. The relevant interests, present and future, are fully represented by the two parties, and their judgment about the appropriate standard of care is probably more accurate, over the run of cases, than would be that of any external arbiter such as a court. And in fact, we find that the negligence standard is understood to be a default rule subject to express modification by the parties' agreement. ${ }^{128}$

2. Intermediate Relations. - Bailment also gives rise to relations that can be described as compound-paucital or quasi-multital. Bailees who deal in large numbers of standardized transactions, such as parking lots and coat check rooms, frequently issue receipts or tickets that seek to define the terms of the bailment agreement. This is a classic compoundpaucital situation: The identities of the parties are definite and the rights and duties attach to particular persons, but there are large numbers of bailors engaged in identical transactions with a single bailee. Such relationships are generally characterized by asymmetric information, and not surprisingly, we find that the receipts and tickets issued by bailees in these situations often seek to disclaim the bailment relationship or to impose very low limits on the bailee's liability. ${ }^{129}$

Given the compound-paucital nature of the relationship, we would expect to find the law intervening to regulate these sorts of disclaimers, either by requiring prominent disclosure (the notice strategy) or by invalidating such disclaimers (the protection strategy). Because bailors in such circumstances usually have rather small stakes in the transaction (once the value of the bailed good is discounted by the probability of loss or destruction), it is not plausible to expect much ex ante contracting over the precise terms of standard form disclaimers of liability. Protection thus seems a more plausible strategy in this context. In fact, we find

126. See Ayres \& Gertner, Filling Gaps, supra note 10, at 89-90 (summarizing literature).

127. See Posner, supra note 66 , at 104-05 (explaining why the parties have a mutual interest in minimizing the cost of performance under a contract).

128. See Brown, supra note $122, \S 11.5$, at 274 .

129. The two most widely used devices are to characterize the relationship as a license rather than a bailment, e.g., Allen v. Hyatt Regency-Nashville Hotel, 668 S.W.2d 286, 288-90 (Tenn. 1984) (discussing whether owner of car stolen from a self-park garage was a bailor or a licensee), or to limit liability to a particular dollar amount of loss, e.g., Allright, Inc. v. Elledge, 508 S.W.2d 864, 869 (Tex. App. 1974) (refusing to enforce contract limiting liability of garage for loss or damage to car to $\$ 100)$. See generally A. Darby Dickerson, Note, Bailor Beware: Limitations and Exclusions of Liability in Commercial Bailments, 41 Vand. L. Rev. 129, 138-55 (1988). 
evidence of fairly widespread legislative intervention to regulate limitations on liability on the part of bailees in these situations, ${ }^{130}$ and some evidence of judicial policing through doctrines such as unconscionability. ${ }^{131}$

Bailment also gives rise to relations that can be described as quasimultital. Consider in this connection cases involving misdelivery of bailed goods. Misdelivery occurs when the bailee mistakenly hands the property over to a third party without the bailor's consent. The bailor (in the typical case) has a contractual relationship with the bailee. But the bailor cannot enter into a contract with the third party, at least not at the time the bailment takes place, because the identity of the third party at that time is indefinite. The bailor's relationship with the third party will be governed by the bailor's general in rem rights against "all the world." Pursuant to these rights, the bailor is of course entitled to demand that the third party return the goods or make good for their loss. But the third party may be difficult to locate, or may be judgment-proof.

Although the bailor cannot contract directly with the third party, the possibility of misdelivery is an issue that the bailor and bailee could address by contract at the outset of their relationship. The parties could specify the standard of care to which the bailee will be held in seeking to prevent misdelivery, the damages that will be paid should misdelivery occur, and so forth. Notice, however, that both parties but especially the bailor are likely to have incomplete information about the risk of misdelivery, more so than with respect to the risk of loss and destruction of the property. One problem is that there is a moral hazard dimension to misdelivery: Because misdelivery confers a benefit on a third party, the bailee may be tempted to connive with a third party to "misdeliver" the property, and it will be difficult for the bailor to prove that this has happened. At a more mundane level, the bailee will always have a better sense for the type of controls it has in place to prevent misdelivery, and of how difficult it will be to recover the property from the typical third party to whom misdelivery may occur.

Given these informational asymmetries, it would not be surprising if we found a greater degree of legal intervention in cases of misdelivery

130. Statutes often limit the ability of bailees who are common carriers, hotels, and the like, to limit their liability, see 14 Am. Jur. 2d Carriers $\$ \$ 1255-67$ (2000), and sometimes prevent commercial parties such as auto parks from disclaiming or limiting their liability by contract, see, e.g., Mass. Gen. L. ch. 231, § 85M (West 1972); Commodore Leasing, Inc. v. Metro. Dist. Comm'n, 450 N.E.2d 1097, 1098 n.1 (Mass. App. Ct. 1983). More general statutory provisions may also constrain the ability of commercial parties to adopt liability limitations, see, e.g., Cal. Com. Code $\S 1102(3)$ (West Supp. 2001) (providing that U.C.C. general obligation of good faith, diligence, reasonableness, and care may not be disclaimed, but agreement can alter the standard to measure these duties if not unreasonable).

131. See Carr v. Hoosier Photo Supplies, Inc., 441 N.E.2d 450, 454-56 (Ind. 1982) (upholding limitation of liability of photo processor and distinguishing decisions finding such limitations printed on receipts unconscionable). 
than with respect to ordinary loss and destruction of bailed goods. As it turns out, the traditional rule is that bailees are strictly liable for misdelivery, as opposed to the standard of reasonable care that prevails with respect to loss or destruction. ${ }^{132}$ Commentators have sometimes found the higher standard of care applied in cases of misdelivery puzzling. ${ }^{133}$ The difference cannot be explained in terms of the degree of harm to the bailor. The bailor loses the property in either case. Indeed, the loss is if anything less severe in the case of misdelivery, because there is some chance that the property can be recovered from the third party who has erroneously received it.

The higher standard of care that traditionally applies to misdelivery begins to make more sense, however, once we realize that misdelivery is a quasi-multital situation that entails greater uncertainty because of the introduction of the indefinite third party. The rule of strict liability seeks to correct for the unequal information between the bailor and bailee about the risk of transfer to a third party. Strict liability here serves to protect the bailor much in the way a penalty default rule protects the informationally disadvantaged party in the law of contracts.

If the strict liability standard were subject to waiver upon express negotiation of a contrary rule as part of the bailment agreement, then the analogy to penalty default rules would be complete: The rule would either force the bailee to disclose additional information about the risk of misdelivery, or failing notice, would provide protection against the risk of misdelivery. The case law, however, while admittedly not extensive, suggests that the standard of strict liability for misdelivery is not subject to waiver. Professor Helmholz reports in a recent survey of the cases that bailees who have sought to take advantage of contract terms limiting liability in cases involving misdelivery "have generally failed." 134 In other words, the law appears to adopt a protection strategy here rather than a notice strategy, contrary to our general prediction about the expected rules in quasi-multital situations.

At first blush, this seems anomalous. Given the contractual relationship between the bailor and bailee, the bailor can in theory account for the risk of misdelivery by adjusting the compensation of the bailee or making arrangements for insurance. For example, a bailor who agrees to a standard of negligence for misdelivery by a dry cleaning shop can expect to pay less for cleaning services than would be the case if the shop

132. See Restatement (Second) of Torts $\S 234$ (1965); Brown, supra note 122, at $\S 11.7$.

133. See Helmholz, supra note 115 , at 99 (stating that " $[\mathrm{i}] \mathrm{t}$ is hard to see any good reason" for the distinction). A number of cases have applied the reasonable care standard to the misdelivery situation. See id. at 124-27 nn.127-39 (citing authorities). Although Professor Helmholz, in a recent survey of the cases, found some movement in this direction, he also reports that strict liability "remains the law applied in most of the American cases." Id. at 129.

134. Id. at 131. 
were strictly liable for misdelivery. To be sure, because the identity of the person to whom the property is misdelivered is indefinite ex ante, the risk would be difficult to calculate. Shirts erroneously delivered to a neighbor can be easily retrieved; shirts delivered to a stranger passing through town will be gone forever. Thus, many bailors would not want to bear this risk. Still, as long as attempts by bailees to limit their liability for misdelivery were subject to duties of especially prominent disclosure, modifications in the default rule would be permitted. ${ }^{135}$

On further analysis, however, the immutable rule of strict liability-a form of protection strategy-may be explainable in this context. Bailments are usually routine transactions and most bailors have relatively little at stake with respect to the risk of misdelivery of any particular bailed good. Thus, it is doubtful that very many bailors would have an incentive to inform themselves about benefits and costs of agreeing to a modification of the default standard of care for misdelivery. In other words, most misdelivery cases arise in what we have called compoundpaucital situations, pairing large numbers of bailors with small stakes in each transaction against a bailee with much larger stakes in the aggregate. If the misdelivery cases commonly have features that are compound-paucital as well as quasi-multital, then the misdelivery problem comes close to having all the elements of a pure in rem relation. A standardized protection strategy, rather than a notice strategy, is thus to be expected.

3. In Rem Relations. - Cases involving the in rem rights of bailors are difficult to uncover because, in the ordinary case where such rights are in issue, the fact that the owner is also a bailor is likely to be irrelevant. For example, suppose an owner consigns a painting to an art dealer for sale and then the painting is stolen from the dealer by a third party. In a suit by the owner to recover the painting from the third party, the fact that the painting was subject to a bailment at the time of the sale is irrelevant and will not enter into analysis of the rights of the respective parties. Still, it is possible to detect the influence of the bailor's retained in rem rights in decisions involving claims of conversion or contractual deviation by the bailee. ${ }^{136}$

The conversion and contractual deviation cases involve claims that the bailee has acted directly contrary to the bailor's retained in rem rights. This is easiest to see in connection with claims of conversion. The bailee, by converting the property to his own use, is clearly violating the duty to protect the bailor's retained in rem ownership rights. For all the reasons usually given for treating many intentional torts more harshly

135. The hornbook rule is that all attempts to limit liability by bailees must be express and ambiguities are construed in favor of the bailor. See $8 \mathrm{~A} \mathrm{Am}$. Jur. 2d Bailments $\S 91$ (1997). Thus, to some extent, existing law employs a strong default rule without regard to whether the issue is negligent loss or destruction or misdelivery.

136. See Helmholz, supra note 115, at 113-24 (discussing theories of conversion and contract deviation and cases invoking these doctrines). 
than torts of negligence, ${ }^{137}$ it makes sense to seek to discourage this kind of violation of the bailor's property rights by applying a rule of strict liability.

Conversion also creates a problem of ostensible ownership. The bailee, by consuming or selling the property, is in effect holding himself forth to the world as a true owner. This gives rise to potential confusion among third parties, causing them to incur higher information costs about the status of property rights. To be sure, the law provides a measure of protection to third parties who purchase objects from bailees for value without notice of the superior rights of the bailor. ${ }^{138}$ Still, the application of the bona fide purchaser rule in this context turns on specific facts, such as lack of notice and whether the bailee is a merchant selling the goods in the ordinary course of business, and thus leaves significant residual uncertainty for third parties. ${ }^{139}$ The more conversion by bailees, the more residual uncertainty for third parties. This will cause third parties to engage in more information gathering about title to property than would be the case in a world with less conversion. These higher information costs provide a further reason to discourage such behavior on the part of bailees by making them strictly liable for conversion.

Somewhat less obviously, the contract deviation cases can also be seen as entailing a direct violation of the bailor's retained in rem rights and as creating potential confusion about ownership. These cases involve bailees who have used the property in ways not contemplated by the bailment contract. An owner, of course, is free to use property any way she wants. A bailee is limited to using the property for the purposes defined by the bailment agreement. A bailee who uses property in ways that deviate from the agreement is acting like an owner rather than a bailee. Whether such behavior will create confusion for third parties will depend on the facts. But it is not implausible that in many cases-for example where a museum allows a gallery to exhibit a painting of which the museum is merely a bailee-there is a problem of ostensible ownership. In order to discourage this kind of behavior, it again may make sense for the law to respond with a rule of strict liability for losses caused by contractual deviation.

137. See William M. Landes \& Richard A. Posner, The Economic Structure of Tort Law 149-89 (1987) (analyzing intentional torts that involve deliberate wrongdoing or recklessness and showing why harsher treatment is warranted than in case of negligence).

138. The general rule in America is that a bona fide purchaser cannot acquire title from a thief. See Saul Levmore, Variety and Uniformity in the Treatment of the GoodFaith Purchaser, 16 J. Legal Stud. 43, 57-58 (1987) [hereinafter Levmore, Variety and Uniformity]. But the Uniform Commercial Code has relaxed this rule where the bona fide purchaser acquires the property from someone to whom it has been "entrusted," for example by bailment. See U.C.C. § 2-403(1)-(3) (1989 \& Supp. 2000) (amended 1989); see also Porter v. Wertz, 416 N.Y.S.2d 254, 257-58 (N.Y. App. Div. 1979) (discussing application of 2-403(2) in a case involving bailment of a painting).

139. See U.C.C. $§ 2-403(2)$. 
If strict liability makes sense in cases of conversion and contractual deviation, should the rule of strict liability in these cases be regarded as a default rule or as an immutable rule? Given the general interest in discouraging bailees from acting toward the property in such a way as to create the appearance of ostensible ownership, an immutable rule would appear to be appropriate here. Bailees who create false appearances of ownership can cause confusion among a variety of third parties who deal with the bailee, the bailor, or the property. Because of high transaction costs, these third parties cannot negotiate offsetting adjustments to account for the additional confusion. Thus, arguably the higher standard of care should not be subject to contractual modification.

The law appears to be largely in accord. It should come as no surprise that the courts have held that liability for conversion cannot be waived by contract. ${ }^{140}$ As Helmholz notes, "In such circumstances, bailees will have committed an intentional act entirely inconsistent with their undertaking as a bailee, and it would be unjust to allow them to pay less than the full value of the goods in consequence." 141

Liability for contractual deviation, in contrast, would seem as a matter of logic to be amenable to waiver, since strict liability in these cases is based on a theory of breach of contract. If the contract waives liability for these claims, then there would be no breach of contract and hence no liability. Helmholz reports, however, that limitations on liability are generally not enforced in this context either. ${ }^{142}$ Consistently with the ostensible ownership concern, judges have assumed that general clauses limiting liability apply only to claims for loss and destruction of bailed property, but not to claims for losses caused by deviation from contract.

In sum, the doctrinal pattern reflected in bailment law appears to be largely although not entirely consistent with our hypotheses. When the relationship is purely in personam-a claim by the bailor that the bailee has lost or destroyed property - then the law tends to apply a general default rule of reasonable care, subject to contractual modification by the parties' agreement. This is the type of doctrine commonly associated with the law of contracts. In intermediate cases involving compoundpaucital and quasi-multital relations we find, as expected, evidence of substitution of rules designed to protect bailors who have incomplete information about risks. These rules all adopt a protection strategy rather than a notice strategy, even in the cases of quasi-multital risks. This is contrary to our general prediction, although the deviation can perhaps be explained by the fact that the stakes in most bailments are too small to sustain ex ante negotiations to account for such risks. Finally, when the

140. See Aetna Cas. \& Sur. Co. v. Higbee Co., 76 N.E.2d 404, 408-09 (Ohio Ct. App. 1947); see also William K. Jones, Private Revision of Public Standards: Exculpatory Agreements in Leases, 63 N.Y.U. L. Rev. 717, 730 (1988) (noting that exculpatory clause will not insulate landlord from liability for intentional misbehavior).

141. Helmholz, supra note 115, at 132.

142. Id. at 131 . 
situation most clearly implicates the retained in rem rights of the bailor, we find as predicted that the law gravitates toward an immutable rule of strict liability, in other words, a more bright-line rule characteristic of the type of doctrine associated with the law of property.

\section{B. Landlord-Tenant Law}

A more complex institution that straddles the boundary between contract and property is landlord-tenant law. As in the law of bailments, there is a longstanding debate over whether leases should be classified as a contract or as the conveyance of an estate in land, i.e., a property right. ${ }^{143}$ This debate assumed considerable prominence in the 1960s and 1970s, as tenants' rights lawyers urged the wholesale revision of established tenets of landlord-tenant law to provide greater protection for tenants, especially low-income tenants. ${ }^{144}$ A primary weapon in this campaign was the contention that traditional rules of landlord-tenant law are a vestige of outmoded "feudal" property concepts. Reformers urged that these rules be discarded in favor of concepts associated with bilateral contracts, as in the provisions governing sales of goods under the Uniform Commercial Code. ${ }^{145}$

The campaign was extraordinarily successful, at least for a time. Spurred by the D.C. Circuit's decision in Javins v. First National Realty Corp. ${ }^{146}$ which fully endorsed the notion that existing landlord-tenant rules are a product of outmoded feudalism, ${ }^{147}$ an "implied warranty of habitability" in residential leases spread rapidly in the early 1970s. ${ }^{148}$

143. For overviews, see Roger A. Cunningham, The New Implied and Statutory Warranties of Habitability in Residential Leases: From Contract to Status, 16 Urb. L. Ann. 3, 5-10 (1979) (chronicling rise of contract-type warranties of habitability); Mary Ann Glendon, The Transformation of American Landlord-Tenant Law, 23 B.C. L. Rev. 503, 503-09 (1982).

144. See, e.g., Hicks, supra note 2, at 541-44 (discussing various remedies newly available to urban tenants under contract theory of leases); Hiram $\mathrm{H}$. Lesar, Landlord and Tenant Reform, 35 N.Y.U. L. Rev. 1279, 1289-90 (1960) (arguing for statutory and judicial elimination of common law landlord-tenant rules in favor of contractual approach).

145. See, e.g., Glendon, supra note 143, at 503-05 (describing widespread belief among jurists in the superiority of the contract model of lease but arguing that movement toward contract happened earlier and is giving way to public regulation).

146. 428 F.2d 1071 (D.C. Cir. 1970).

147. The court was emphatic in its condemnation of the property conception:

The assumption of landlord-tenant law, derived from feudal property law, that a lease primarily conveyed to the tenant an interest in land may have been reasonable in a rural, agrarian society . ... But in the case of the modern apartment dweller, the value of the lease is that it gives him a place to live. Id. at 1074 .

148. For examples of later decisions following Javins, see, e.g., Park West Mgmt. Corp. v. Mitchell, 391 N.E.2d 1288, 1291-95 (N.Y. 1979) ("A residential lease is essentially a sale of shelter and necessarily encompasses those services which render the premises suitable for the purpose for which they are leased."); Green v. Superior Court, 517 P.2d 1168, 1169-70 (Cal. 1974) ("[A] warranty of habitability is implied by law in residential leases in California."); Marini v. Ireland, 265 A.2d 526, 534 (N.J. 1970) ("It is eminently fair and just 
Other innovations derived from contract law soon followed, such as a general duty on the part of the landlord to mitigate damages when a tenant defaults and abandons the premises. ${ }^{149}$

The landlord-tenant law reform effort eventually lost steam. ${ }^{150}$ This may have been due in part to the realization that the problems of lowincome tenants are more a function of general levels of employment and income than rules of landlord-tenant law. Indeed, plausible arguments were made that loading up on tenants' rights was not in the best interests of low-income tenants as a class. This was because the new rights had the potential to cause higher rents and a reduced supply of housing. ${ }^{151}$ Much turns on empirical issues such as the nature of the rental market, the preferences and activities of marginal consumers, and landlords' ability to distinguish sophisticated and unsophisticated tenants, ${ }^{152}$ but our purpose in this section is merely to explain the pattern of legal intervention in this area. For whatever reason, the courts drew up short of completely adopting a contract model for all situations, much to the dismay of some commentators. ${ }^{153}$ As a result, landlord-tenant law today remains an amalgam of property-law and contract-law principles.

In retrospect, it is easy to see how certain elements of landlord-tenant law were ripe for reform, and that the reform should take the form of adopting modern contract precepts. Landlord-tenant relations have a very large in personam aspect. Leases look like contracts, setting forth in terms called covenants the description of the property, the length of the term, the rent, the major promises about the condition of the property, and so forth. These reciprocal obligations between the landlord and the tenant can easily be seen as elements of a bilateral services contract. Hence it is not surprising that standard contract doctrines such as mutual

to charge a landlord with the duty of warranting [a part of] a building . . . rented for residential purposes is fit for that purpose ....”); see also Cunningham, supra note 143, at 74-81 (listing cases finding implied warranty of habitability).

149. See, e.g., Austin Hill Country Realty, Inc. v. Palisades Plaza, Inc., 948 S.W.2d. 293, 295-300 (Tex. 1997); Schneiker v. Gordon, 732 P.2d 603, 610-12 (Colo. 1987); Sommer v. Kridel, 378 A.2d 767, 769 (N.J. 1977).

150. See Gerald Korngold, Whatever Happened to Landlord-Tenant Law?, 77 Neb. L. Rev. 703, 707-08 (1998).

151. See Charles J. Meyers, The Covenant of Habitability and the American Law Institute, 27 Stan. L. Rev. 879, 889-97 (1975); see also Posner, supra note 66, at 514-18. For a contrary argument, see Bruce Ackerman, Regulating Slum Housing Markets on Behalf of the Poor: Of Housing Codes, Housing Subsidies and Income Redistribution Policy, 80 Yale L.J. 1093, 1093-1102 (1971) [hereinafter Ackerman, Regulating Slum Housing]. But see Richard Craswell, Passing on the Costs of Legal Rules: Efficiency and Distribution in Buyer-Seller Relationships, 43 Stan. L. Rev. 361, 380-85 (1991) (analyzing and noting various interpretations of Ackerman's model and arguing that sellers' ability to pass on costs is only relevant on a zero-sum redistributionist view).

152. See sources cited in supra note 111.

153. See, e.g., Robert H. Kelley, Any Reports of the Death of the Property Law Paradigm for Leases Have Been Greatly Exaggerated, 41 Wayne L. Rev. 1563, 1568-72 (1995) (arguing that the "problem" is "courts that have stated that tenancies are to be construed using the contract law paradigm apparently have not really meant it"). 
dependency of covenants, the duty to mitigate damages, and implied warranties of fitness can be adopted to resolve disputes between landlords and tenants over the interpretation of these terms. ${ }^{154}$

On the other hand, it is also not surprising that courts did not adopt a pure contract model of leases. A lease is at bottom a transfer of the right to control the use and enjoyment of the premises from one partythe landlord-to another-the tenant. ${ }^{155}$ Indeed, probably the most important attribute of a lease from the tenant's perspective is the transfer of in rem rights associated with ownership for the duration of the lease term. These rights include the rights to exclude others from premises, to use the premises as the tenant sees fit without interference from others (subject to specific restrictions on particular uses in the lease), and to transfer the lease interest to third parties (again, subject to specific lease restrictions). In other words, from the tenant's perspective the largest benefit of the in personam bargain known as a lease is the transfer of the package of in rem rights generally associated with ownership. Given the mixed nature of leases-they are at once contracts and conveyances of ownership rights-we would expect courts to draw up short before endorsing the proposal to make landlord-tenant law purely contractual. ${ }^{156}$

As in the case of bailment law, our objective is not to determine whether leases are properly classified as property or contract, but to test whether the law in this area will take on the features of contract in those areas where information costs are borne largely by the two parties concerned (in personam rights), and will exhibit features of property law where more widespread information costs are implicated (in rem rights). Landlord-tenant law is complex and covers a multitude of issues. We must therefore be less than comprehensive in our survey.

1. In Personam Relations. - We start by considering relations that appear to be wholly in personam, in the sense that they largely if not exclusively affect the interests of the parties to the immediate lease-the land-

154. Many states have adopted one or more of these provisions. See, e.g., MedicoDental Bldg. Co. v. Horton \& Converse, 132 P.2d 457, 462-65 (Cal. 1942) (adopting mutual dependency of covenants); Sommer, 378 A.2d at 769 (adopting general duty of landlord to mitigate damages); Hilder v. St. Peter, 478 A.2d 202, 208 (Vt. 1984) (adopting implied warranty of habitability). The implied warranty of habitability has been adopted most widely. See infra note 175 .

155. See Olin L. Browder, The Taming of a Duty-The Tort Liability of Landlords, 81 Mich. L. Rev. 99, 100 (1982) (noting that "it is of course absurd" to contend that leases are not in part conveyances of property rights).

156. For an example of how the "property" conception of leases can benefit even lowincome tenants, consider Grant v. Detroit Ass'n of Women's Clubs, 505 N.W.2d 254 (Mich. 1993). The club hired a caretaker as an employee at will, and gave him as his sole compensation an interest that the court concluded was a lease in the premises. Id. at 255. When the caretaker was fired, the court held that the lease was not automatically terminated, but could be extinguished only by following the proper state law procedures for terminating a leasehold. Id. at 259. In other words, the employment contract created an interest that had the more enduring features of a property right, and this interest outlaster the employment relationship. 
lord and the tenant. One issue that would appear to fall into this category is the risk of physical damage to, or destruction of, the premises. The common law rule here was defined by the law of waste. ${ }^{157}$ The tenant was under a duty to preserve the premises from damage or destruction and to return them to the landlord at the end of the lease in roughly the same condition they were in at the beginning, reasonable wear and tear excepted. Thus, the tenant had an implied duty to repair, unless the premises were destroyed by a third party or an act of God. And the tenant's duty to pay rent continued even in the event of a fire or other major casualty that destroyed or severely impaired the value of the premises. ${ }^{158}$

Dating from a period well before the landlord-tenant law reform movement got underway, legislation has been adopted in nearly all jurisdictions modifying this common law allocation of risk, at least with respect to residential tenancies. ${ }^{159}$ These statutory reforms make sense as attempts to identify the appropriate majoritarian rule under changing circumstances. The old rule associated with the law of waste was probably an accurate reflection of what most parties would negotiate for in a world in which the paradigmatic lease was farmland and associated structures. The tenant farmer was the proverbial "jack of all trades" and worked on site. The landlord was often an absentee owner, and was poorly situated to make repairs or control for risks such as fire. ${ }^{160}$ In contrast, in the context of modern leases of residential property and especially apartment rentals, the landlord is typically in a better position to make repairs and assume the risk of major losses. Thus, the statutory reforms here reflect a plausible calculus that the correct majoritarian rule requires a different allocation of risk than it once did. ${ }^{161}$

Note that both the original common law rule and the modern statutory modifications are default rules. The traditional rule allocating the risk of loss and destruction of the premises to the tenant was always understood to be subject to modification by contrary agreement in the

157. See 1 American Law of Property $\S 3.78$, at 347 (1952).

158. See Paradine v. Jane, 82 Eng. Rep. 897, 897-98 (K.B. 1647).

159. See 1 Milton R. Friedman, Friedman on Leases $\$ 9.2$, at 517-28 (4th ed. 1997) (providing a survey of the statutes, including history prior to the 1960s).

160. See Robert C. Ellickson, Property in Land, supra note 62, at 1373 n.291 (noting that "[a]bsentee farm landlords appear to date back to the beginning of recorded history," discussing alternative landowner/occupant arrangement, and citing sources); see also, e.g., Cornelius J. Moynihan, Introduction to the Law of Real Property 76 (2d ed. 1988) ("The old rules that had their source in a rural agricultural society were found to be unsuited to an urban society faced with a critical housing shortage."); Deborah Hodges Bell, Providing Security of Tenure for Residential Tenants: Good Faith as a Limitation on the Landlord's Right to Terminate, 19 Ga. L. Rev. 483, 486 (1985) (arguing that no-repair rule may have suited earlier agricultural leases which, unlike residential leases, were largely characterized as a conveyance of land).

161. See 1 Friedman, supra note $159, \S 9.2$, at 517 ; id. $\S 10.101$, at 610 (summarizing the argument for modifying the common law rule with respect to residential tenancies). 
lease. ${ }^{162}$ Thus, under the traditional rule the parties were free to (and often did) impose the duty to make repairs on the landlord, and the parties were free to (and sometimes did) shift the risk of loss of rental value due to destruction of the premises from the tenant to the landlord. According to the leading treatise, the statutes that change the common law allocation of risk also universally provide that the rules are subject to modification in the lease. ${ }^{163}$ Thus, the new rules are also defaults, as we would expect given the in personam nature of the issue.

A second in personam relationship concerns the remedies available to landlord and tenant in the event of a breach by the other. The law here is immensely complicated, and we can provide only the crudest outline of the major issues.

The early common law adopted the understanding that lease covenants are independent. ${ }^{164}$ Thus, a breach of a covenant by the landlord, for example, a covenant to supply manure to an agricultural tenant, did not excuse the tenant from the covenant to pay rent. ${ }^{165}$ The tenant's remedy was to continue paying rent and sue the landlord for damages. Conversely, breach of a covenant by the tenant, such as the covenant to pay rent, did not excuse the landlord from the covenant of quiet enjoyment, that is, the promise to transfer undisturbed possession of the premises to the tenant for the duration of the term. The landlord's remedy was to leave the tenant in possession until the term expired, and sue for damages equal to unpaid rent. ${ }^{166}$

Predictably, the reformers assailed the common law rule of independent covenants as a relic of feudalism. They urged that leases be treated in this respect just like any other bilateral contract, in which covenants are assumed to be dependent rather than independent. ${ }^{167}$ Thus, a material breach of a covenant by the landlord (e.g., to provide heat) would give rise to a full menu of contract remedies on the part of the tenant, including the possibility of rescission of the lease. On the other hand, if the tenant defaulted on rent and abandoned the premises, the landlord could not simply sit by and allow the claim for damages for unpaid rent to mount. The landlord, like other promisees under the law of contract, (1980).

162. See Robert S. Schoshinski, American Law of Landlord and Tenant § 5:18, at 269

163. See 1 Friedman, supra note $159, \S 9.202$, at $532-34$.

164. See Paradine v. Jane, 82 Eng. Rep. 897, 897-98 (K.B. 1647).

165. Cf. Sutton v. Temple, 152 Eng. Rep. 1108, 1112 (Ex. 1843) (holding that contaminated manure pile and pasture that killed tenant's cattle did not excuse tenant from obligation to pay rent).

166. See Schoshinski, supra note $162, \S 6: 1$, at 377 .

167. See, e.g., Hicks, supra note 2, at 464-69 (discussing rise of implied mutually dependent lease covenants). But cf. Stephen A. Siegel, Is the Modern Lease a Contract or a Conveyance?-A Historical Inquiry, 52 J. Urb. L. 649, 663-70 (1975) (arguing that independence of lease covenants could "accomplish perfect justice"). 
should have a duty to mitigate damages, for example by seeking a substitute tenant. ${ }^{168}$

The substance of the reform proposal was sound, but the characterization of the issue was overstated. The stark contrast between the remedial rules associated with the seventeenth-century leases and those associated with modern bilateral contracts ignored the fact that the common law in the intervening years had developed remedial doctrines, such as constructive eviction and surrender-and-acceptance, that considerably softened the hard edges of the original theory of independent covenants. ${ }^{169}$ Moreover, the doctrine of independent covenants had always been regarded as a default rule subject to contractual modification. For example, landlords have long included so-called "forfeiture" clauses in leases that declare the tenant's right of possession forfeited upon nonpayment of rent, and courts routinely enforce these clauses. ${ }^{170}$

Still, the reformers are probably correct that the remedial doctrine associated with modern bilateral contracts represents a more plausible majoritarian default than does the doctrine of independent covenants, certainly with respect to residential tenancies, and perhaps for commercial tenancies as well. ${ }^{171}$ In other words, modern contract remedies are closer to the package of remedies for which most parties would bargain if they fully attended to the issue in negotiating the lease. Thus, concerns about retroactivity aside, ${ }^{172}$ it would be better to start with the assumption that ordinary contract remedies apply, subject to negotiation of different remedies by the parties, than to persist with the old defaults grounded in independent covenants.

Both allocation of risk of loss and the dependence of covenants implicate in personam relations and therefore do not present informational problems to third parties. In both areas, we find evidence that the law has shifted as the rule most parties would want has changed, yet we also find that the law has consistently dealt with these issues through default rules. Both findings are consistent with our general theory.

2. Intermediate Relations. - As in the case of bailment, we also see relationships in landlord-tenant law that correspond to what we have called the compound-paucital and quasi-multital situations. Leases of residential property, especially in large apartment complexes, tend to be

168. See Sommer v. Kridel, 378 A.2d 767, 773 (N.J. 1977).

169. See 2 Friedman, supra note $159, \S 16.302$, at 1097-1115 (discussing surrender and acceptance); 3 id. $\S 29.3$, at 1635-59 (discussing constructive eviction).

170. See Schoshinski, supra note $162, \S 6: 1$, at $380-82$.

171. For an economic model of some of the considerations bearing on this question, see Thomas J. Miceli et al., The Property-Contract Boundary: An Economic Analysis of Leases, 3 Am. L. \& Econ. Rev. 165 (2001).

172. The main concern with switching defaults in this context is transitional. Thousands of leases in every jurisdiction have been drafted with the traditional defaults in mind, and many of these leases are still in force. See e.g., Julian v. Christopher, 575 A.2d 735, 739-41 (Md. 1998) (making change in landlord tenant law prospective only in recognition of reliance on prior rule in drafting leases). 
standard form agreements. The landlord has a large stake in the legal content of these leases; each tenant has a much smaller stake (in terms of absolute dollars involved). Not surprisingly, the standard form leases used in these circumstances tend to be drafted from a pro-landlord perspective. This would appear to be a classic instance of a compoundpaucital relationship, characterized by incomplete information, especially on the part of the tenant.

The presence of this compound-paucital issue provides one possible explanation for the emergence of the modern implied warranty of habitability (IWH) in residential leases. The common law adopted a rule of "caveat lessee" regarding the condition of the premises. Unless the premises contained some latent defect known to the landlord and not discoverable through reasonable inspection, the tenant took the premises "as is." ${ }^{173}$ The reformers attacked this rule relentlessly, with all the usual arguments about how caveat lessee was the product of a bygone era when leases were primarily agricultural, and did not make sense in the context of modern residential tenancies.

The reformers achieved great success in reversing the doctrine of caveat lessee, at least with respect to residential tenancies. ${ }^{174}$ Drawing in part on the U.C.C.'s implied warranties of merchantability and fitness for purpose, and partly on legislated housing codes, all but a handful of states have now rejected caveat lessee in favor of the IWH. ${ }^{175}$ This reform effort would fit comfortably into the preceding analysis about switching default rules to conform to probable majoritarian preferences, save for one thing: Although the IWH is subject to waiver under the Restatement and in some jurisdictions, ${ }^{176}$ most courts, following the lead of the D.C. Circuit, have held that the warranty is mandatory and not subject to modification by the parties. ${ }^{177}$

There are a variety of explanations for why courts have generally made the IWH an immutable rather than a default rule, ${ }^{178}$ including the

173. See, e.g., Siegel, supra note 167 , at $672-73$ (describing the origins and gradual decline of the caveat lessee rule).

174. Most courts that have considered the issue have declined to extend the IWH to commercial leases. See Schoshinski, supra note 162, § 3:29, at 147-48 \& n.61 (citing cases).

175. See 1 Friedman, supra note $159, \S 10.101$, at 614 n.17 (noting that all but six states have adopted some form of the IWH).

176. See Restatement (Second) of Property, Landlord and Tenant, § 5.6 (1977) (permitting knowing waiver by tenant if, inter alia, there is not "significant inequality of bargaining power").

177. See Javins v. First Nat'l Realty, 428 F.2d 1071, 1082 n.58 (D.C. Cir. 1970) (“Any private agreement to shift the duties would be illegal and unenforceable."). See generally Edward Chase \& E. Hunter Taylor, Jr., Landlord and Tenant: A Study in Property and Contract, 30 Vill. L. Rev. 571, 642-46 (1985) (describing the developments in IWH doctrine following the Javins decision).

178. One is doctrinal. If the source and content of the IWH is the local housing code, not an implied contractual term, then the IWH can be seen as, in effect, an implied private right of action recognized by courts under a public regulatory law. Since on this theory the 
possibility that the reform effort here is a misguided attempt to use legal rules to modify the distribution of income. ${ }^{179}$ But one explanation would be that the courts have in effect opted for a protection strategy, rather than a notice strategy, based on the perception that contracting over the issue is likely to be distorted by informational asymmetries. The argument would be that, given the relatively small dollar amounts at stake for the tenant in a typical residential lease, it is unrealistic to expect prospective tenants to invest in acquiring information about the meaning of lease terms, including waivers of the IWH, or thoroughly to investigate the conditions of the premises. ${ }^{180}$ Certainly, it would not be cost effective for a tenant to retain a private lawyer at market rates to review a lease (in contrast to the practice in most jurisdictions of having a lawyer review the provisions of a commercial lease or a contract for the purchase of a house or condominium) or to hire an architect to inspect the premises (again in contrast to the practice in many jurisdictions with respect to the purchase of existing homes). Thus, given the landlord's superior information about the law and the facts regarding the quality of the premises, and the low probability that it will be cost effective for tenants to acquire sufficient information to negotiate over the issue, arguably it makes sense to interpose minimum standards of quality and make those standards nonwaivable.

We also see evidence of relations that are quasi-multital, particularly those that arise when a nontransferring party (either the tenant or the landlord) has rights against an indefinite but small number of persons to whom the other party has transferred her interest. One example is the landlord's transfer of the underlying property to a third party without the tenant's consent. The established rule here is that the new owner takes the property subject to all existing leases and lease terms. ${ }^{181}$ In effect, the landlord's transferee steps into the shoes of the landlord and assumes all of the landlord's obligations under existing leases toward the nontransferring tenant. The rule assumes that the tenant has a property right, which has been carved out of the landlord's larger interest, typically a fee simple. If leases were bilateral contracts and nothing more, then in the

IWH derives from positive law, it makes sense that it not be subject to contractual modification.

179. For debate over whether mandatory quality standards can be used to achieve a redistribution of income in favor of poor tenants, see generally Ackerman, Regulating Slum Housing, supra note 151 (arguing that under certain restrictive conditions, such as no exit by landlords from the market, redistribution is possible); Neil K. Komesar, Return to Slumville: A Critique of the Ackerman Analysis of Housing Code Enforcement and the Poor, 82 Yale L.J. 1175 (1973); Bruce Ackerman, More on Slum Housing and Redistribution Policy: A Reply to Professor Komesar, 82 Yale L.J. 1194 (1973).

180. See Kennedy, supra note 111, at 599; Arthur Allen Leff, Contract as Thing, 19 Am. U. L. Rev. 131, 140-41 (1970) ("[I]n any sector of commerce where . . one party could impose most of its own terms ... . there was nothing to prevent highly disproportionate 'contracts' from being created.").

181. See 3 Friedman, supra note $159, \S 36.1$, at 1810 ; Schoshinski, supra note 162 , $\S 8: 3$, at $539-40$. 
event of a sale of the fee arguably the new owner could evict the tenant (because the burden of the lease would not run with the land), and the tenant would be left with nothing but a cause of action against the original landlord for breach of contract.

Imposing the existing lease terms on the landlord's transferee clearly performs a protection function. The rule is adverse to the informationally advantaged parties (the landlord and the landlord's transferee), who would often prefer to allow the new landlord to renegotiate the lease, and is protective of the informationally disadvantaged party (the tenant), who knows nothing about the new landlord and is vulnerable to being held up in any renegotiation because of sunk costs and other reliance interests associated with the existing lease.

In addition, however, the rule that the landlord's transferee takes subject to existing lease terms performs a notice function. It turns out the rule is only a default, although a strong one: Lease clauses providing that the lease terminates upon sale of the underlying fee to a third party have been enforced by courts if they are prominently disclosed and have received the affirmative assent of the tenant. ${ }^{182}$ What the rule means in practice, therefore, is that any landlord who contemplates the possibility of a future transfer of the fee and who wants to allow the transferee to terminate or renegotiate the lease must incorporate an express provision in the original lease spelling out this contingency. The tenant is therefore put on notice that this may happen, and can either consent or not consent to the inclusion of this provision in the original lease.

Treating the rule as a strong default rather than an immutable rule probably makes sense in this context. It is true that subjecting the tenant to early termination or forced renegotiation can be extremely disruptive to the tenant's reliance interests. But there may be circumstances, as where there is a vacancy in a building that is the subject of prolonged negotiations for sale and conversion to another use, in which a tenant can be induced (no doubt in exchange for reduced rent) to accept a lease on these terms. Thus, the rule permits overrides-but only if the tenant is clearly on notice at the time of the original lease and affirmatively consents to the override, signaling that the override is in the interest of both parties.

The story is similar, although the legal mechanism for dealing with incomplete information is different, when the tenant transfers the leasehold to a third party without the landlord's consent. The analysis of the situation is symmetrical to that in the case of the sale of the fee subject to a lease. The tenant and a third party have entered into a contract to

182. See Schoshinski, supra note $162, \S 8: 3$, at 539; 1 Herbert Thorndike Tiffany, The Law of Landlord and Tenant $\S 12$, at 70-84 (1910). Although the caselaw is sparse, it also appears that the default rule here is a strong one: Courts will be scrupulous about requiring that the clause be unambiguous and prominently disclosed, and that the lessee fully comprehend its import. See id. at 75 (suggesting that termination on sale must be provided for with specificity and lease must provide for express notice to lessee). 
transfer the tenant's interest without the landlord's consent, and this transfer is potentially threatening to the landlord's interests. ${ }^{183}$ The tenant's transferee may be a poor credit risk, may trash the premises, or may disrupt other tenants, for example. Viewed from the perspective of the landlord, the tenant's transferee is part of the indefinite class of other persons to whom the tenant may transfer his interest, and about whom the landlord has no information before the transfer occurs.

In theory, the law might respond to this problem in a fashion analogous to the rule about landlord transfers: It could prohibit all tenant transfers unless the tenant has disclosed the possibility of a future transfer when the original lease is negotiated, and has obtained the landlord's consent to a mechanism for handling such transfers. This would protect the nontransferring party (the landlord) and provide notice of the possibility of future tenant transfers. But the law does not proceed in this fashion. The default rule is that if the lease is silent on the issue, the tenant can assign or sublet at any time to any transferee of the tenant's choosing. ${ }^{184}$

One possible explanation for putting the burden on the landlord rather than the tenant to raise the issue of tenant transfers in the original lease negotiations is familiar from our discussion of compound-paucital relations: Tenants, especially residential tenants, may have too little at stake to acquire the information necessary to initiate negotiation over the issue of future tenant transfers. Landlords are likely to be more sophisticated about the issue, and thus are generally capable of protecting themselves without the benefit of a penalty default rule. This is confirmed by practice: The standard-form leases used by landlords routinely include provisions requiring some kind of landlord consent before any tenant transfer takes place. ${ }^{185}$

183. The landlord owns the reversion, which for present purposes can be said to include both the present value of the future stream of rental payments and the value of the fee after expiration of the lease-collectively, the amount the landlord could obtain by selling the fee interest subject to the lease.

184. At common law, the tenant is usually free to transfer the leasehold by assignment or sublease, unless the landlord has included a clause in the original lease expressly forbidding such transfers. See 1 Friedman, supra note 159, § 7.2, at 290; Schoshinski, supra note $162, \S 8: 10$, at $552-53$. Moreover, the emerging rule is that the landlord may refuse to consent to a tenant transfer under a no-assignment clause only on grounds that are commercially reasonable, unless the right to refuse for any reason has been expressly reserved. See Julian v. Christopher, 575 A.2d 735, 738-41 (Md. 1990); Kendall v. Ernest Pestana, Inc., 709 P.2d 837, 849 (Cal. 1985). Standing alone, these rules would not suggest that the law shows any special solicitude for the interests of the nontransferring party, the landlord. We argue below that the law does in fact show solicitude for landlords in the face of tenant transfers, but it does so through the standardized rules that define the consequences of subletting and assigning ex post, rather than by policing the agreement between the landlord and tenant ex ante.

185. See 5 Thompson on Real Property $\S 44.08$ (c) (1), at 456-57 (David A. Thomas ed., 1994). 
Nevertheless, the law does not rely entirely on landlord self-help through the imposition of appropriately protective clauses in the original lease. The law utilizes other devices for overcoming the informational problems posed by tenant transfers, namely, standardizing the legal forms in which tenant transfers take place, and imposing standardized consequences that protect the landlord when transfers do occur. The law recognizes onily two forms of tenant transfer: assignment and sublease. Courts sometimes say that the question whether a tenant transfer is an assignment or sublease is to be determined by construing the "intentions" of the parties. ${ }^{186}$ But what they appear to mean by this is that the parties are free to signal their intentions as to which of the two forms they have adopted, not that they are free to customize a new form of transfer. In practice, courts follow standardized rules for identifying assignments and subleases. A complete transfer of the tenant's interest is almost always deemed to be an assignment; a partial transfer is almost always deemed to be a sublease. ${ }^{187}$

Moreover, each of the two options has standardized consequences that are generally protective of the landlord's interests. If the transfer is an assignment, then the assignee is deemed to be bound by all material covenants of the original lease-even though there is no privity of contract between landlord and assignee. ${ }^{188}$ The transferee in effect steps into the shoes of the transferring tenant, and must abide by all material promises of the original lease. If the transfer is a sublease, then the original tenant is deemed to be bound to perform all covenants of the original lease-notwithstanding the transfer of possession to the subtenant. ${ }^{189}$ The original tenant in this case continues to be liable for the performance of all promises in the original lease. In either case, the rules incorporate a guarantee of performance of the material terms of the original lease, thereby protecting the interests of the nontransferring party-the landlord. It is possible that the standardized rules of assignment and subletting could be modified by very explicit language in the original lease, but examples of this happening are hard to find. ${ }^{190}$

In short, the law follows a curiously different path with respect to tenant transfers. But in the end, it reaches a similar result to the one that

186. See, e.g., Ernst v. Conditt, 390 S.W.2d 703, 707 (Tenn. Ct. App. 1964) (noting that the intentions of the contracting parties are the primary basis for distinguishing an assignment of a lease from a sublease); Jaber v. Miller, 239 S.W.2d 760, 764 (Ark. 1951) (holding that "the intention of the parties is to govern in determining whether an instrument is an assignment or a sublease").

187. See 1 Friedman, supra note $159, \S 7.401$, at 362-63; Schoshinski, supra note 162 , $\S 8: 10$, at 553 .

188. See 2 Powell on Real Property $\S 17.04[2][a]$ (1994).

189. See id.

190. In Roman law, transfers by the usufructuary (the Roman analogue of the tenant) to third parties were prohibited altogether. See Richard A. Epstein, Why Restrain Alienation?, 85 Colum. L. Rev. 970, 983-84 (1985). The common law has substantially relaxed this rule, but still insists on a strong default imposing standardized duties. 
prevails in the area of landlord transfers: The law adopts rules that serve to protect the interests of the nontransferring party (here the landlord), but does so in a way that allows for mutually advantageous adjustments in the original relationship.

The standardized rules of assignment and subletting serve other functions as well. They reduce the amount of information third parties must assimilate in order to assess the consequences of stepping into the shoes of the tenant. In addition, those evaluating leaseholds in general will have less information to process if there are only two forms of tenant transfer; these information costs borne by the rest of the world generally are lessened by standardization. Once again, third-party effects and standardization go hand in hand.

3. In Rem Relations. - On occasion, landlord-tenant law deploys even more standardized rules of the type associated with pure property rights. We will consider two examples.

One mandatory rule is easily accounted for under our framework: The tenant enjoys the same general right to exclude trespassory invasions from the premises, as defined by the ad coelum rule, ${ }^{191}$ as does the holder of any other possessory interest in property. The case law that enforces this understanding is difficult to uncover, because the landlord-tenant dimension is irrelevant to the issue. For example, if a tenant leases a parking space, and a third party repeatedly parks her car in that space, the tenant may sue in trespass, seeking an order requiring the third party to stop interfering with the parking space. In this lawsuit, the fact that the tenant holds the right to the parking space by lease rather than fee simple is irrelevant, and nothing in the analysis of the issue will turn on this fact. ${ }^{192}$ Nevertheless, the understanding is clear, given that the lease represents a transfer of the landlord's in rem rights of ownership to the tenant during the term of the lease.

The only real issues that arise concern the tenant's right to exclude the landlord herself. ${ }^{193}$ A covenant of quiet enjoyment is implied in every lease, and this generally prohibits the landlord or someone acting at her direction from interfering with the tenant's possession. Although authority is sparse, an attempt by the landlord to override the covenant by a provision in the lease would almost certainly be unenforceable; such a provision would contradict the very notion of a lease. ${ }^{194}$ However, more narrowly drafted exceptions to the tenant's right to exclude, such as a covenant permitting the landlord to show the premises to prospective

191. See supra note 98 .

192. See 2 Powell, supra note $188, \S 16$ B.02[2] ("Once initial possession is established ... it is clearly the tenant's responsibility to ward off trespassers.").

193. See 1 Friedman, supra note $159, \S 4.202$, at $95-100$.

194. Cf. 3 Friedman, supra note $159, \S 29.303$, at 1658 (discussing decision invalidating a lease clause purporting to waive liability for constructive eviction, which rests on the covenant of quiet enjoyment). 
tenants before expiration of the lease term or to inspect the premises for needed repairs, have been upheld. ${ }^{195}$

Somewhat more difficult to explain is the law's recognition of only four types of leases-the term of years, the periodic tenancy, the tenancy at will, and the tenancy at sufferance. ${ }^{196}$ The parties are expected to conform their agreement to one of the recognized categories, which have standardized definitions and consequences spelled out in every hornbook. Contractual modification is not permitted; if the parties create a novel type of lease, it will be categorized as being of one of the four recognized types, presumably the one that most closely approximates what the parties intended. This limitation on the recognized number of lease forms is a manifestation of the numerus clausus principle, about which we have previously written. ${ }^{197}$

If the only interests at stake were those of the original contracting parties, then such standardization would make little sense. If the landlord and tenant wish to enter into a lease defined on some other basis-a tenancy "for the duration of the war" is the classic example ${ }^{198}$ - why not let them? The tenant may have a unique need for such a customized lease term-for example, to secure warehouse space related to the supply of war material-and the landlord may be perfectly willing to oblige. Classifying the tenancy for the duration of the war as either a periodic tenancy or a tenancy at will thus frustrates the intentions of the parties and makes it harder for them to accomplish their purposes. ${ }^{199}$

195. See Tiffany, supra note $182, \S 3$ (b) (2), at 9-13.

196. See 2 Powell, supra note 188, $\S 16.03-.06$; Schoshinski, supra note 162, $\S \S 2: 1-2: 26$, at $30-83$.

197. See Merrill \& Smith, supra note 9, at 13, 22-23.

198. See, e.g., Nat'l Bellas Hess, Inc. v. Kalis, 191 F.2d 739, 740-41 (8th Cir. 1951) (holding that a lease which ends upon the signing of the peace treaty ending World War II does not create a valid tenancy for years because although the signing of such a treaty is certain there is substantial uncertainty as to when it will occur); Lace v. Chantler, [1944] K.B. 368 (C.A.) (same).

199. Most courts that have considered the effect of language purporting to create a lease for the duration of the war have held that this creates either a tenancy at will or a periodic tenancy, not a term of years. See, e.g., Nat'l Bellas Hess, 191 F.2d at 740 (finding tenancy at will); Stanmeyer v. Davis, 53 N.E.2d 22, 25 (Ill. App. Ct. 1944) (finding tenancy at will); Michael Tuck Found. v. Hazelcorn, 65 N.Y.S.2d 387 (N.Y. Mun. Ct. 1946) (finding tenancy at will); Lace, [1944] K.B. at 369 (finding periodic tenancy). Those courts that have upheld such conveyances as a term of years have done so either by redefining the meaning of a term of years, see Smith's Transfer \& Storage Co. v. Hawkins, 50 A.2d 267, 268 (D.C. 1946) (holding that lease for the duration of the war was a valid term of years because a term of years does not require a certain date of termination, only certainty that it will terminate at some date), or by recharacterizing the agreement of the parties, see Great N. Ry Co. v. Arnold, 33 T.L.R. 114, 115 (K.B. 1916) (enforcing lease for duration of war on the theory that the parties' agreement was the functional equivalent of a lease for 999 years "terminable with the conclusion of the war"). Thus, none of these decisions squarely takes issue with the proposition that there are only four types of leasehold estates; they disagree only over the proper classification of a lease for the duration of the war within this fixed universe of permitted types. 
The problem with permitting such customized lease terms is that they would increase the costs that third parties must incur in understanding the property rights that exist in the society and are available for potential exchange. For example, potential purchasers of the landlord's reversion, or potential assignees or subtenants of the tenant's interest, would incur higher measurement costs in ascertaining the nature of a lease interest if customized lease terms were permitted. Similarly, creditors of the landlord or the tenant will be able to process information about the nature of the interest of the debtor more easily if leases come in standardized legal packages. Finally, prospective future tenants will benefit from lease standardization, because they can more readily determine when or if a particular property will be available to lease in the future. The point is not simply that higher costs will be incurred when actual instances of customized leases are encountered. All third parties will incur higher measurement costs if any customization is permitted, since all must then investigate in each case to see if such a special interest has been created. ${ }^{200}$

To sum up, landlord-tenant law conforms fairly closely to our hypotheses. We find that in personam relations are governed by rules that shift over time in ways that plausibly reflect changing majoritarian preferences, but these rules are always defaults. Moreover, consistent with our surmise that the law will often adopt a protection strategy in the compound-paucital situation, the modern rule that addresses the condition of the premises, the IWH, can plausibly be viewed as a form of protection strategy adopted in a context where tenants remain rationally ignorant and are vulnerable to strategic behavior by landlords. We also find rules that serve the dual function of protection and notice in the quasi-multital situations created by landlord and tenant transfers to third parties. The in rem aspects of landlord-tenant law are similar to the in rem aspects of fee simple ownership: We find standardized forms and bright-line rules of exclusion.

\section{Security Interests}

Security interests also lie at the intersection of property and contract. There has long been controversy over whether a security interest is a contract to convey an interest in property upon the occurrence of a future contingency-nonpayment of debt-or whether it is an inchoate prop-

200. Consider the problems that a potential purchaser of the underlying fee or a prospective tenant would incur in determining when a customized tenancy "for the duration of the war" will end. Does it end upon armistice, on demobilization, or only with the signing of a peace treaty? Who is to make the determination that the war has ended? Since there will be no body of precedent resolving these ambiguities, the adoption of such an idiosyncratic lease term clearly compounds the measurement costs that must be incurred by a variety of third parties. The intrusion of the numerus clausus principle into an institution that is otherwise highly in personam thus makes sense as a means of reducing third-party information costs. 
erty right that springs into a full possessory right upon the occurrence of the future contingency. ${ }^{201}$ Clearly security interests have aspects of both property and contract, and thus satisfy our definition of a borderline institution. It should be noted that, perhaps more than the other areas of law we examine, security interests present a number of challenging puzzles that have led to a large literature. ${ }^{202}$ The costs and benefits of security interests have been quite controversial in a number of respects, and it is not our purpose to enter these debates here. Instead, as before, we will show in this Section that both the contours of present law and the patterns of criticism by commentators reflect an implicit concern with information costs. ${ }^{203}$ The pattern of standardization following from the involvement of third parties broadly holds.

When a lender makes a loan to a debtor, the lender may take a security interest in property (collateral) of the debtor. The security interest is created by the security agreement, a species of contract that is, not surprisingly, interpreted according to contract principles. The security interest gives the lender two rights that an unsecured lender does not have. First, the lender has what is called a "property right" or "repossessory right," which means that upon default the lender can seize the collateral without having to resort to judicial process. ${ }^{204}$ Second, a secured lender has a "priority right," which means that under state law, the lender can enjoy this property right in the face of competing claims of purchasers, transferees, and other creditors. ${ }^{205}$ Bankruptcy may stay or suspend these rights, and we return to standardization in bankruptcy later. ${ }^{206}$

201. See Julia Patterson Forrester, Bankruptcy Takings, 51 Fla. L. Rev. 851, 873-77 (1999) (documenting controversy over property status of security interests and taking position that they are property interests even for takings purposes).

202. This even includes the question of why firms issue security and whether this is a net social good. See, e.g., Lucian Arye Bebchuk \& Jesse M. Fried, The Uneasy Case for the Priority of Secured Claims in Bankruptcy, 105 Yale L.J. 857, 862 n.23 (1996) (collecting literature on priority of secured debt).

203. As we will see, the commentary taken as a whole sometimes makes different and more fine grained distinctions than does current law. For our purposes, the important thing to note is that these proposals are consistent with the expectations of our information-cost theory.

204. See Douglas G. Baird \& Thomas H. Jackson, Cases, Problems, and Materials on Security Interests in Personal Property 1, 67 (1984) [hereinafter Baird \& Jackson, Security Interests]. Under the Uniform Commercial Code, a security interest is a property interest. U.C.C. $\S 1-201(37)(2000)$.

205. Baird \& Jackson, Security Interests, supra note 204, at 1, 67.

206. See infra notes $239-41$ and accompanying text. Where a debtor is insolvent, the exercise of the property right is stayed under bankruptcy law, and the priority right is suspended, but in place of the state law priority right, the Bankruptcy Code requires that the secured loan be paid before certain other interests up to the value of the collateral. See 11 U.S.C. $\$ \S 361-64$ (2000). In practice, secured creditors may not be paid full value. See, e.g., Bebchuk \& Fried, supra note 202, at 911-13. 
A security interest may be taken in personal or real property. Under the U.C.C. as enacted in all states, ${ }^{207}$ a party with a security interest in personal property has priority over unsecured parties and over later-created security interests unless the later security interest is filed or perfected before the earlier one. ${ }^{208}$ Perfection normally involves a filing of the financing statement in the prescribed place, ${ }^{209}$ or taking possession of the collateral, ${ }^{210}$ with the filing system being reminiscent of title filings in real estate. Likewise, mortgages of real property are subject to the filing requirements of the state in which the property is located. These systems vary but all of them require some form of notice for the benefit of potential subsequent purchasers and lenders.

The parties affected by security interests can be usefully classified in terms of the third-party interests that they do or do not implicate. First, the parties to the security agreement themselves, with respect to issues relating to the agreement, are in an in personam relationship. A borrows from B and gives B a security interest. If this is A's first loan from any source, then A and B may at this stage take actions that affect others (and each other) but are not yet affected by actions of others.

Second come the intermediate cases, which can be of the compound-paucital or the quasi-multital sort. Compound-paucital issues arise where one lender enters into a large number of similar small-stakes contracts with debtors (as happens in consumer finance). More characteristically complicated in the area of security interests are what we call quasimultital issues. These mainly involve the rights of parties affected only indirectly by the security agreement. Future lenders to A may be affected by the existence and terms of the security agreement. In addition, any future loans they make can impair B's ability to collect on the original loan. Furthermore, either party might assign its interest in the property

207. Article 9, that part of the U.C.C. governing security interests in personal property and fixtures, has been revised and is in the process of being enacted by the states. Revised Article 9 is scheduled to become effective on July 1, 2001. See Steven L. Harris \& Charles W. Mooney, Jr., Introduction to the Symposium on UCC Revised Article 9, 74 Chi.-Kent L. Rev. 857, 857 (1999).

208. U.C.C. $\$ 9-312(5)$. This assumes that there is no intervening period in which the secured party who is first to file or perfect left the security interest unperfected and unfiled. Revised Article 9 moves in the direction of a nontemporal perfection hierarchy based in part on the method of perfection. See Randal C. Picker, Perfection Hierarchies and Nontemporal Priority Rules, 74 Chi.-Kent L. Rev. 1157, 1158-59 (1999).

209. The prescribed place is often different under Revised Article 9, and the new system is different in that the priority rules do not depend entirely on time. Under old Article 9, the rule was first to file or perfect, U.C.C. \$ 9-312(5), but under the new rules possession by control receives extra priority. U.C.C. app. XVI $\$$ 9-104 to 107 (setting forth provisions of the revised U.C.C. Article 9 providing for establishment of control over deposit account, electronic chattel paper, investment property, and letter-of-credit rights); U.C.C. app. XVI $\S \S 9-327$ to 330 (setting forth provisions of the revised U.C.C. Article 9 providing priority rules relating to the foregoing types of property).

210. Exceptions include the automatic perfection of purchase money security interests. See U.C.C. $\S \S 9-107,9-312(3)$ to (4). 
to third parties. Thus, in addition to the original parties, at least two other groups-future lenders and assignees-are within what we might call the "zone of privity"; these parties all deal directly or indirectly with A or B. ${ }^{211}$ Under circumstances to be discussed shortly, all such parties have an incentive to take into account the effect of the security interest on the value of all present and future rights in the collateral. Consequently, aspects of the security agreement that hurt the future lenders or assignees are likely to be capitalized into the value of the rights in the hands of the decisionmakers (A and B).

Third and finally, some third parties are not in a contractual relationship with $\mathrm{A}$ and $\mathrm{B}$, even indirectly; they have a purely in rem relationship with $\mathrm{A}$ and $\mathrm{B}$. These include in rem dutyholders trying to avoid violating the property rights of either $\mathrm{A}$ or $\mathrm{B},{ }^{212}$ as well as involuntary creditors, especially tort creditors, of A. ${ }^{213}$ The security agreement between $\mathrm{A}$ and $\mathrm{B}$ could impinge on the rights and affect the behavior of these third parties. ${ }^{214}$ This class of third parties also includes those who engage in secured lending with parties other than A and B and with reference to assets not owned by A. The mere possibility that A and B might have invented an idiosyncratic security interest will raise the cost of processing security interests having nothing directly to do with A and B's transaction. That is, as with property interests generally, the possibility of creating new and idiosyncratic security interests raises information costs to others generally. The question then becomes whether it is worthwhile to standardize the ways of taking security and who-private parties themselves, intermediaries, or the government-can best supply such standards. ${ }^{215}$

1. In Personam Relations. - The relationship between A and B is in personam and with respect to this relationship we would expect to find

211. We introduced the notion of a zone of privity in this sense in our earlier article. See Merrill \& Smith, supra note 9, at 28.

212. This would include those who might damage the property or possibly bailees of the property. See Douglas G. Baird \& Thomas H. Jackson, Possession and Ownership: An Examination of the Scope of Article 9, 35 Stan. L. Rev. 175, 177-78 (1983) [hereinafter Baird \& Jackson, Possession and Ownership].

213. A variety of commentators have noted the special problems associated with involuntary (especially tort) creditors. See Bebchuk \& Fried, supra note 202, at 882-83; Lynn M. LoPucki, The Unsecured Creditor's Bargain, 80 Va. L. Rev. 1887, 1898-99 (1994); Alan Schwartz, Taking the Analysis of Security Seriously, 80 Va. L. Rev. 2073, 2085-86 (1994) [hereinafter Schwartz, Taking the Analysis]; James H. Scott, Jr., Bankruptcy, Secured Debt, and Optimal Capital Structure, 32 J. Fin. 1, 2-3 (1977); Paul M. Shupack, Solving the Puzzle of Secured Transactions, 41 Rutgers L. Rev. 1067, 1094-95 (1989).

214. Under a regime of complete freedom to customize, as compared with a system that provides for some degree of standardization of in rem rights, potential tortfeasors and tort victims both might have too much incentive to take precautions that minimize their losses from nonstandard rights. See, e.g., Schwartz, Taking the Analysis, supra note 213, at 2085 ("If the injurer is not fully insured and if actual victims will get little in the injurer's bankruptcy, then potential victims may take excessive precautions to avoid harm.").

215. See Merrill \& Smith, supra note 9, at 49-51. 
that the law adopts legal rules typical of the law of contract. It may be that $\mathrm{A}$ and $\mathrm{B}$ wish to communicate with each other at low cost and that using a standard vocabulary and proposing standard devices to govern their relationship is advantageous. But the benefits and costs of doing so are internal to A and B. It is a complicated question in any given type of transaction whether the costs of communicating fall ultimately on one party or the other, ${ }^{216}$ and it is certainly the case that outsiders like courts will sometimes be called upon to interpret the agreement. But none of these problems with security interests-considering A and B and possibly courts as the only affected parties-goes much if at all beyond similar problems in contracts generally. Thus, as far as A and B are concerned we would not expect any greater degree of standardization than normally found in contract law. ${ }^{217}$ Not surprisingly, we find that security interests are generally interpreted in accordance with contract principles. ${ }^{218}$ Where the law imposes terms or mandates notice to the world, this is justified mainly as protection of parties other than A and B. ${ }^{219}$

2. Intermediate Relations. - As with our other institutions, the intermediate cases in the area of security interests can be of the compoundpaucital or the quasi-multital type. With regard to the former, it is quite common for lenders to enter into a large number of similar secured transactions with consumers, as for example in financing the purchase of automobiles and major appliances. In these sorts of transactions, individual consumers do not have a large incentive to investigate the fine points of the credit agreement. There is a wide range of range of possible market-based solutions to the problem, including reliance on lenders with

216. For some studies that focus on which party in a transaction will undertake and/ or bear the costs of producing information, see Yoram Barzel, Measurement Cost and the Organization of Markets, 25 J.L. \& Econ. 27, 28 \& n.3 (1982); Victor P. Goldberg, The Gold Ring Problem, 47 U. Toronto L.J. 469, 480 (1997); Roy W. Kenney \& Benjamin Klein, The Economics of Block Booking, 26 J.L. \& Econ. 497, 518-19 (1983).

217. Even potential problems such as wasteful efforts at signaling the quality of projects through security interests are not really unique to security interests; the potential for signaling to be privately beneficial but socially wasteful (rather than cost-effectively informative) is a theoretical possibility in other two-party transactions. See, e.g., Philippe Aghion \& Benjamin Hermalin, Legal Restrictions on Private Contracts Can Enhance Efficiency, 6 J.L. Econ. \& Org. 381, 382 (1990) (describing how prohibition of signaling has potential to enhance welfare); Ayres \& Gertner, Contractual Inefficiency, supra note 94, at 761 (describing how argument for default rules that force information out of parties "is strongest when transaction costs are small"). Whether a given example of signaling is wasteful is difficult to tell, Schwartz, Taking the Analysis, supra note 213, at 2085, and the tendency has been to overestimate the waste associated with information costs where markets encourage devices to reduce wasteful information production, see Yoram Barzel, Some Fallacies in the Interpretation of Information Costs, 20 J.L. \& Econ. 291, 292 (1977).

218. U.C.C. $\$ 9-201$ (2000) ("Except as otherwise provided by this Act a security agreement is effective according to its terms between the parties, against purchasers of the collateral and against creditors.”).

219. See Baird \& Jackson, Possession and Ownership, supra note 212, at 177-78 (arguing that "judges and legislators should be sensitive to the costs imposed on third parties by the separation of ownership and possession whenever these costs exist"). 
reputations for honesty, following the lead of sophisticated marginal consumers, or seeking out the advice of consumer organizations and rating agencies. But it is probably no coincidence that here, as in landlord-tenant law, we find consumer-protection laws that inject standardized duties into contractual relations designed to protect informationally disadvantaged parties. ${ }^{220}$

In the other type of intermediate area-what we call quasi-multital relations - the notice strategy generally predominates over the protection strategy. With respect to future lenders to A or future assignees of A's or B's property interest, the argument for some type of standardized form of notice of the existence of the security interest is widely recognized, although not entirely uncontroversial. ${ }^{221}$ The large literature on security interests has explored the informational effects of security interests on later (and earlier) creditors. Other intermediate cases arise with assignments and purchases.

For all these parties, especially later creditors, there is clearly a need for information about the security interest. The mandatory rules for perfecting security interests in personal property furnish notice to other creditors in much the same way that recording systems in real estate do. ${ }^{222}$ As in other contexts in which legal rules impose a standardized form of notice, such rules are justified to the extent that the needed information will not be supplied privately. ${ }^{223}$

Whether such information would in fact be provided without legally standardized notice is the subject of a lively debate in the literature. It has been argued that if borrowers without security interests have an incentive to advertise this fact and if they can furnish credible information (e.g. from opening their books and files), then there is no need for mandatory rules of priority, 224 and perhaps not even for a rule of constructive notice-by-filing (or of possession). ${ }^{225}$ These proposals make the most sense in contexts in which the concern of transactors for the marketability of their assets will give them sufficient incentive to standardize without government intervention. Even if mandatory rules are not strictly

220. For a survey and discussion of mandatory rules in consumer finance, see Richard Hynes \& Eric Posner, The Law and Economics of Consumer Finance, passim (John M. Olin Law \& Economics, Working Paper No. 117, 2d Series, Feb. 20, 2001).

221. Compare Baird \& Jackson, Possession and Ownership, supra note 212, at 182-83 (endorsing filing system as cost-effective method of furnishing notice to later creditors) with Alan Schwartz, A Theory of Loan Priorities, 18 J. Legal Stud. 209, 220-22, 249-59 (1989) [hereinafter Schwartz, A Theory] (arguing for abandoning filing and relying on contract with respect to priority among creditors).

222. See, e.g., Baird \& Jackson, Possession and Ownership, supra note 212, at 183.

223. See Merrill \& Smith, supra note 9, at 49-51.

224. Schwartz, A Theory, supra note 221, at 218-26 (arguing for the dispensibility of notice function of filing system and presenting model of separating equilibrium in credit markets); George G. Triantis, Secured Debt Under Conditions of Imperfect Information, 21 J. Legal Stud. 225, 249-50 (1992) (discussing borrower incentives to communicate private information given imperfect information in the market for security interests).

225. See Schwartz, A Theory, supra note 221, at 220-22. 
needed here, however, the law might supply focal points in order to facilitate the process of coordination. In other contexts involving small-scale interests, the need for stronger legal pressure to standardize is likely to be greater. ${ }^{226}$

In our framework, this debate reflects the intermediate nature of the information problem. Where the interests involved go beyond the in personam, we expect a greater degree of legal intervention to supply either notice or protection (or both) to parties with incomplete information. And this is by and large what we find in the legal rules governing security interests, with the emphasis here on notice. The notice requirements and the priority rules tend not to constrain substantively what can be done with security interests, because the creditors could in principle contract for different priority. ${ }^{227}$ But the basic rules of priority cannot be varied by contract; the requirements for perfection and the resolution of remaining conflicts among security interests are handled by standardized mandatory rules. ${ }^{228}$ We do not suggest that the system in its current form provides exactly the optimal level of default strength. But the system does seem clearly to be aimed at providing third parties with information.

As for later purchasers, security interests (like bailments and leases) divide ownership in such a way that third parties may have difficulty discovering or processing the rights. ${ }^{229}$ These issues are particularly acute where a third party is trying to acquire all the rights in the asset in question. Protections for third-party purchasers, especially where information costs are high, are also a feature of the law of security interests. Later purchasers, unlike later creditors, may find it impracticable to do credit

226. The repossessory right may be more important in this regard than the priority right (the latter being the focus of attention). Consider trade creditors, who shade off into involuntary creditors. In some cases of "nonadjusting creditors" it will not be worth it for good types to signal that they are good types to lenders. So if there is a pooling equilibrium, it makes sense for the law to standardize, because parties will not be affected by the impact on the nonadjusting creditors of nonstandard security interests.

227. This is only a tendency because the law does not facilitate some agreements. Negative pledge covenants, for example, are usually unenforceable against third parties, which make such covenants of little practical use. See Carl S. Bjerre, Secured Transactions Inside Out: Negative Pledge Covenants, Property and Perfection, 84 Cornell L. Rev. 305, 306-07 (1999) (critiquing current negative covenant doctrine and proposing that negative covenants be made enforceable against subsequent perfecting secured parties). Some scholars have criticized the system for this, and have suggested remedial proposals for notice through perfection. See id.

228. See U.C.C. $\$ \$ 9-312$ to $9-315(2000)$. The concern with third-party information costs is distinct from the issue of whether full priority for security interests in bankruptcy imposes an externality on nonadjusting creditors. See, e.g., Bebchuk \& Fried, supra note 202, at 891-903 (discussing inefficiencies created by full priority); Steven L. Schwarcz, The Easy Case for the Priority of Secured Claims in Bankruptcy, 47 Duke L.J. 425, 485-88 (1997) (arguing that secured debt actually benefits all creditors, even secured creditors); Symposium, The Priority of Secured Debt, 82 Cornell L. Rev. 1279 (1997).

229. Baird \& Jackson, Possession and Ownership, supra note 212, at 177-78. 
checks and evaluate disclosed financial information. ${ }^{230}$ As expected, the legal rules here take the form of strong defaults; security interests can be maintained but only through taking steps designed to ensure notice.

The problems faced by third-party purchasers also help explain the U.C.C.'s provisions that a person with voidable title has the power to transfer good title to a good faith purchaser for value, ${ }^{231}$ and a merchant who is "entrust[ed]" with goods of the kind in which the merchant deals has the power to transfer "all rights of the entruster [e.g., a bailor] to a buyer" acting in good faith and without notice of the superior title. ${ }^{232}$ These rules in effect impose a rule of strict liability on the true owner subject to a defense of prior notice to the third party purchaser. Crucially, as Richard Epstein points out, the defense of notice does not hold the third party to a negligence standard. The third party need not have undertaken all cost effective steps at investigating the transferor's ownership; to benefit from the rule of strict liability on owners, the third party need only not ignore the obvious (e.g. jewelry offered at a fraction of its value). ${ }^{233}$ Again, we are not arguing that these rules are the best solution to the problem of the third-party purchaser. ${ }^{234}$ But they are quite consistent with the kinds of solutions we find in other areas where intermediate-level information-cost problems arise. Here, as elsewhere, the law adopts rules designed to protect parties with incomplete information and to create incentives for informationally advantaged parties to provide notice. ${ }^{235}$

Finally, the asset-partitioning function of security interests also helps to lower information costs by reducing the overall monitoring costs associated with secured lending. Security interests focus a creditor's monitoring on selected assets for which that creditor may have an advantage in monitoring, thereby promoting efficiency. ${ }^{236}$ But such focused monitor-

230. Schwartz, A Theory, supra note 221, at 223. For this reason, Schwartz advocates adopting a first-in-time rule for disputes between creditors but retaining the filing system for conflicts between creditors and purchasers. Id.

231. U.C.C. $\S 2-403(1)$.

232. U.C.C. $\$ 2-403(2)$. The "entrustment" rule speaks of a "buyer in the ordinary course of business." Id. To be a "buyer in the ordinary course of business" requires a good-faith purchase and a lack of knowledge that the sale violates ownership rights or a security interest. Id. $§ 1-201(9)$.

233. Epstein, Inducement, supra note 120, at 15-16.

234. As Saul Levmore has pointed out, the difficulty of the problem is confirmed by the fact that there is no uniform solution across legal systems. See Saul Levmore, Variety and Uniformity in the Treatment of the Good-Faith Purchaser, 16 J. Legal Stud. 43, 44-45, 60 (1987).

235. Even more strikingly, the rules of negotiability are designed to promote reliance on the part of third parties by, in our terms, minimizing the need to incur the costs of measuring reliability. Negotiability is correspondingly a highly standardized area, featuring mandatory rules not subject to customization even with actual notice. See U.C.C. § 3-104 (defining negotiable instrument).

236. See, e.g., Thomas H. Jackson \& Anthony T. Kronman, Secured Financing and Priorities Among Creditors, 88 Yale L.J. 1143, 1152-61 (1979) (discussing the benefits of security interests in focusing monitoring efforts, taking advantage of monitoring 
ing will only work if assets are truly segregated, because otherwise value can only be protected (and hence captured) by more extensive monitoring. ${ }^{237}$ As with organizational law and devices like trusts, this asset-partitioning effect is an essential contribution of the legal rules that govern security interests; it would be prohibitive for creditors to contract individually with every party with whom they might otherwise come into conflict. ${ }^{238}$ In our terms, asset partitioning creates a regime to reduce the costs associated with quasi-multital rights and duties; the potential conflicts here are between parties who are ex ante not definitely specifiable. As expected, in these contexts such asset-partitioning devices have a strong default character.

Similar issues arise in the choice of bankruptcy regime. Commentators have had difficulty explaining why the present bankruptcy regime should be mandatory, and suggestions have recently been made to allow more contracting in this area. ${ }^{239}$ But interestingly this has taken the form of proposing a menu approach: Only a small and finite number of regimes would be available in order to avoid confusion and costly information gathering on the part of potential transactors. ${ }^{240}$ The benefits here

advantages, and thereby lowering monitoring costs); Saul Levmore, Monitors and Freeriders in Commercial and Corporate Settings, 92 Yale L.J. 49, 53-59 (1982) (providing general model of creditor monitoring of "focal points").

237. Specialized monitoring and segregation of assets are closely related; the former can only occur if the value available to the creditor from the asset in question is not impacted by other firm risk that is difficult to detect. On asset substitution and risk substitution more generally, see Hideki Kanda \& Saul Levmore, Explaining Creditor Priorities, 80 Va. L. Rev. 2103, 2123-27 (1994).

238. Henry Hansmann \& Reinier Kraakman, The Essential Role of Organizational Law, 110 Yale L.J. 387, 406-23 (2000). This does not mean that the problem is not also contractual nor that harms by one creditor to another cannot be internalized. See Randal C. Picker, Security Interests, Misbehavior, and Common Pools, 59 U. Chi. L. Rev. 645, 647-48 (1992) (noting that creditors may structure relationships with debtors so as to mitigate common pool problems).

239. See, e.g., Robert K. Rasmussen, Debtor's Choice: A Menu Approach to Corporate Bankruptcy, 71 Tex. L. Rev. 51, 54-55 (1992) (arguing that bankruptcy law is a function of the contract between a firm's investors and its creditors, so firms should have a choice of bankruptcy options); Schwartz, Contract Theory, supra note 4, at 1822-26, 1831 (stating that prohibition on contracting for bankruptcy systems is inefficient, and providing a model in which debtors and creditors contract for bankruptcy systems they prefer). But see, e.g., Lynn M. LoPucki, Contract Bankruptcy: A Reply to Alan Schwartz, 109 Yale L.J. 317, 339-40 (1999) (arguing that Schwartz's bankruptcy contracting model is feasible only in extremely limited scenarios). LoPucki and Schwartz's debate continues in the same volume. Alan Schwartz, Bankruptcy Contracting Reviewed, 109 Yale L.J. 343 (1999) (defending proposal for bankruptcy contracting); Lynn M. LoPucki, Bankruptcy Contracting Revised: A Reply to Alan Schwartz's New Model, 109 Yale L.J. 365 (critiquing Shwartz's "revised" bankruptcy contracting model).

240. Rasmussen, supra note 239, at 53, 65-66, 100; see also Thomas H. Jackson \& Robert E. Scott, On the Nature of Bankruptcy: An Essay on Bankruptcy Sharing and the Creditors' Bargain, 75 Va. L. Rev. 155, 203 (1989) (noting "extraordinary benefits" of limiting bankruptcy regimes to "a few model forms" and arguing that benefits of standardized rules of bankruptcy suggest some restrictions on freedom to opt out). Under Rasmussen's proposal, it is not completely clear whether contracting outside the menu 
would be clearest in the case of small and nonadjusting creditors and least clear in the case of large and repeat creditors; these latter parties may need no more state-supplied standardization than do contracting parties generally.

3. In Rem Relations. - With respect to more distant third partiesthose not even in indirect privity with $\mathrm{A}$ and $\mathrm{B}$ - the law tends to be mandatory in an uncontroversial way. Those parties with a true in rem relationship with $\mathrm{A}$ and $\mathrm{B}$ fall into three classes: tort and other nonadjusting creditors, potential violators of the property rights of $A$ and $B$, and other market participants. With respect to tort creditors, commentators see some benefit in rules designed to afford protection; tort creditors cannot bargain with $\mathrm{A}$ and $\mathrm{B}$ and may take excessive precautions to avoid injury. ${ }^{241}$ Likewise, to the extent that other creditors are nonadjusting they may have a similar need for protective rules.

Potential violators of the property rights of the debtor-owner and the secured party (A and B, respectively) do not figure much in the literature. This is not surprising, because these actors do not present any problems unique to security interests. Moreover, from the in rem dutyholder's point of view, the knowledge needed to avoid violating the rights of the owner and the secured party is not much different from that required to respect an unencumbered fee-simple owner's rights to an asset. Destroying the asset is not allowed in either case, and we do not allow security interests to expand the general in rem duties of respect for property. ${ }^{242}$

With respect to other market participants, the question of whether the law needs to mandate standards as always depends on the incentives of $A$ and $B$ to standardize. If the only entities supplying secured credit (the Bs) were sophisticated institutions concerned about the marketability of these interests (for example, through sales on secondary markets), then arguably legal standardization of priorities and repossessory rights would be unnecessary. But insofar as small-scale lenders and informal security devices enter the picture (as inevitably they do), then even the sophisticated lenders will benefit from some legal standardization. The costs of uncovering and comprehending security interests will drop if all market participants can safely ignore the possibility that novel types of lending practices may be construed by courts as being valid.

would be allowed, but it seems that if it were, it would be subject to a requirement of notice that the menu is not being used.

241. See supra note 213 and sources cited therein; see also Schwartz, A Theory, supra note 221, at 223 (listing the ways in which creditors, but not later buyers, protect themselves against uncertainty).

242. Where problems of potential third-party violations of property rights to the collateral do become more troublesome, as where A puts the property into the hands of a bailee, then we are back into the category of intermediate cases-the quasi-multital rights and duties-discussed in the previous subsection. 
Although most previous literature has framed the issues in security interests in terms of notice-and whether and when parties to a security agreement will have sufficient incentive to reveal the correct amount of information-notice and standardization are complementary methods of reducing information costs and they may well prove to be substitutes at the margin. Many have noted the similarity of security interests to certain leases and bailments, and the question is why each gets different treatment. For example, proposals abound to require the recordation of leases. ${ }^{243}$ In our terms, even though short-term leases are mostly not subject to recordation requirements, they are heavily standardized, in accordance with the numerus clausus principle. ${ }^{244}$ The questions are how close security interests and leases are as substitutes for transactors, and whether the information problems should be solved similarly. Part of this inquiry should include for each method of dividing property a comparison of the frustration costs of standardizing versus the costs of furnishing notice. The problem is finding the right combination of standardization and notice given the range of information problems and the substitutability of methods of dividing property.

To sum up, security interests implicate a range of issues from purely in personam problems, through intermediate cases, to in rem issues. As we move along this spectrum, information costs become more widespread and internalization of them becomes more urgent. As expected, we find that rising information costs to third parties and increased standardization go hand in hand. In the intermediate cases, notice seems to predominate over protection, perhaps because security interests implicate relatively large stakes, making the acquisition of additional information generally a cost effective strategy.

\section{Trusts}

Our final boundary institution - the trust-is the creation of the Anglo-American law of equity. ${ }^{245}$ A trust involves three parties: the settlor, the trustee, and the beneficiary. The settlor conveys property to the trustee, who then manages it as a fiduciary for the benefit of the beneficiary. The trustee holds the "legal" title to the property; the beneficiary is said to hold the "equitable" title. The property that forms the corpus of the trust is typically held in fee simple; today, the most common assets are securities. $^{246}$ The equitable interests of the beneficiaries, in contrast, are often divided in more exotic ways, tracking the building blocks of the

243. See, e.g., Baird \& Jackson, Possession and Ownership, supra note 212, at 187-89 (making proposal to incorporate leases in Article 9's filing rules); see also id. at 189 n.46 (summarizing literature on both sides of the issue).

244. See supra Part III.B; Merrill \& Smith, supra note 9, at 11 (asserting that the numerus clausus principle limits the number of types of possible leases).

245. For the basics, see George T. Bogert, Trusts 1-8 (6th ed. 1987).

246. See, e.g., Roscoe Pound, An Introduction to the Philosophy of Law 236 (1922) ("Wealth, in a commercial age, is made up largely of promises."); Langbein, Contractarian 
estate system-various combinations of life estates, remainders, and concurrent interests. Trusts are used today not only in the transmission of family wealth, where trustees are often individuals or local banks or branches of large banks, but also in the management of charitable institutions, pension funds, mutual funds, and asset securitization, where trustees are normally large banks or financial institutions. ${ }^{247}$

Legal scholars have long debated whether trusts are more properly categorized as a contract-based or a property-based institution. ${ }^{248} \mathrm{Be}-$ cause these kinds of debates are our main criterion for identifying institutions along the property/contract interface, trusts clearly qualify.

Indeed trusts, like our other three institutions, partake of both in personam and in rem relations. A trust involves the transfer of the package of in rem rights associated with ownership from the settlor to the trustee. The trustee exercises managerial authority over the trust corpus, much in the way an owner would: The trustee exercises the right to exclude others, determines when and if to transfer the assets of the trust to third parties, and so forth. ${ }^{249}$ The key difference between a trust and ordinary ownership is that the trustee is subject to a complicated set of duties, tantamount to a third-party beneficiary contract, that requires that the beneficial value of the property be devoted to the welfare of the beneficiary. Thus, we can think of a trust as the transfer of in rem rights associated with ownership, subject to a set of in personam duties designed to fulfill the settlor's intentions toward the beneficiary.

1. In Personam Relations. - Langbein and Hansmann and Mattei have recently explained the functional equivalence between trust law and contract law insofar as the rules that govern the core relationships among the settlor, trustee, and beneficiary are concerned. ${ }^{250}$ For example, they

Basis, supra note 4, at 637-43 (discussing how the trust has shifted from a conveyancing device for freehold land to a management device for holding financial assets).

247. John H. Langbein, The Secret Life of the Trust: The Trust as an Instrument of Commerce, 107 Yale L.J. 165, 177-78 (1997) (documenting the importance of commercial trusts, which contain over $90 \%$ of the assets held in trusts).

248. Maitland and Scott squared off on the issue, the former adopting the contract view, the latter the property position. See Langbein, Contractarian Basis, supra note 4, at 644-46 (reviewing debate between Maitland and Scott). More recently, John Langbein has revived the debate. Although acknowledging that "[ $\mathrm{t}]$ rust is a hybrid of contract and property," id. at 669, Langbein maintains that at bottom "[ $\mathrm{t}$ ] rusts are contracts." Id. at 627. Henry Hansmann and Ugo Mattei have responded that although the core relationship among the settlor, trustee, and beneficiary is primarily contractual, trust law employs rules that could not be replicated by the law of contract insofar as third-party interests enter the picture, such as those of creditors of the trustee. See Henry Hansmann \& Ugo Mattei, The Functions of Trust Law: A Comparative Legal and Economic Analysis, 73 N.Y.U. L. Rev. 434, 454-59 (1998). Thus the debate continues, although in a more sophisticated form than before.

249. The main attribute missing from the trustee's bundle of rights is the right to use the property for the trustee's individual benefit. The beneficial use belongs, by reason of the third-party beneficiary contract, to the beneficiary.

250. Hansmann \& Mattei, supra note 248, at 447-50; Langbein, Contractarian Basis, supra note 4 , at $650-69$. 
note that the principal fiduciary duties of the trustee-the duties of loyalty and prudence-are expressly recognized by the Restatement and other authorities as being default rules subject to contractual modification. ${ }^{251}$ Thus, viewed from an internal perspective, the relations among parties to a trust agreement are governed by legal rules that track the law of contract. We do not attempt to replicate or elaborate on this analysis. We would only note that the rights and duties that exist among the core participants in a trust are in personam: These rights and duties attach to small numbers of persons who are specifically identified. Thus, our general theory would predict that these rights and duties would be articulated in essentially contractual terms, as it turns out they are.

2. Intermediate Relations. - Things start to get more complicated when we turn our attention to relationships that can be characterized as being compound-paucital or quasi-multital. Compound-paucital relations do not usually arise in trusts for purposes of traditional family planning and intergenerational wealth transmission purposes. These instruments tend to be customized to each particular set of circumstances. On the other hand, the trust form is also used today in circumstances that involve large numbers of similarly situated beneficiaries. Examples would include corporate pension funds managed for the benefit of large numbers of employees, mutual funds owned by thousands of investors, and securitized assets such as securitized mortgages or accounts receivable sold to large numbers of investors. In each of these situations it is plausible to say that there is incomplete information as between the settlor or trustee of the fund or the asset on the one hand, and the numerous beneficiaries or investors on the other.

In such compound-paucital situations, our theory suggests that we should find evidence that the law governing such trusts deviates from that which characterizes purely in personam obligations. In particular, we would expect to find greater use of the protection strategy and the notice strategy to overcome informational asymmetries. In fact, we see evidence of both strategies at work. With respect to employee pension plans, the Employee Retirement Income Security Act (ERISA), the federal statute that governs employee benefit plans, imposes nonwaivable fiduciary duties rather than default duties. ${ }^{252}$ This reflects a pure protection approach. Mutual funds and to a lesser degree securitization are also regulated, although the regulatory schemes here tend to take the form of

251. Hansmann \& Mattei, supra note 248, at 449-50; Langbein, Contractarian Basis, supra note 4 , at $655-60$.

252. The statute provides, subject to narrow exceptions, that "any provision in an agreement or instrument which purports to relieve a fiduciary from responsibility or liability for any responsibility, obligation, or duty under this part shall be void as against public policy.” 29 U.S.C. $§ 1110$ (a) (2000). 
mandatory information disclosure rather than nonwaivable fiduciary duties. ${ }^{253}$ In other words, here we find a version of the notice strategy.

What accounts for the use of protection strategy in some compoundpaucital settings and the notice strategy in others? Perhaps one explanation is that there is sufficient demand for monitoring of mutual funds and securitized assets that information disclosure-notice-is all that is required to overcome the problem of incomplete information. With sufficient disclosure, the market will generate private intermediaries who will engage in monitoring for a fee (such as Morningstar), thereby largely correcting for the informational asymmetry. Corporate pension funds, in contrast, may not operate on a sufficient scale to make private monitoring services economically viable. This, in turn, suggests that the protection strategy (as with ERISA's nonwaivable duties) may be the strategy of choice for compound-paucital situations only within a certain range of circumstances: The size of the individual stakes must be sufficiently small to make ex ante contracting economically infeasible, and the number of beneficiaries must also be sufficiently small to preclude the development of a market for private intermediaries that can provide equivalent protection.

Trusts also give rise to relations that can be described as quasi-multital. For example, the trustee can become indebted to a third party, and issues can arise about whether the third party can satisfy the debt out of trust assets to which the trustee has legal but not equitable title. ${ }^{254}$ Other issues can arise about whether the trustee may enter into contracts with third parties for the benefit of the trust and can draw upon trust assets in order to discharge these obligations. ${ }^{255}$ Each of these situations is quasimultital, in that the identity of the third-party creditor is indefinite ex ante (i.e., when the trust is created and the "third-party beneficiary contract" is being drafted among the three principal actors), but the number of such creditors is likely to be small.

As Hansmann and Mattei observe, trust law deviates in significant ways from ordinary contract law in these (quasi-multital) situations. ${ }^{256}$ For example, the individual creditors of the trustee can reach trust assets to satisfy the trustee's personal debts, unless the trustee has registered the trust property as being held "in trust." This looks like a classic penalty

253. Mutual funds are regulated under the Investment Company Act of 1940, 15 U.S.C. $\$ \S 80 \mathrm{a}-1$ to $80 \mathrm{a}-64$; and the Investment Advisers Act of 1940,15 U.S.C. $\$ \S 80 \mathrm{~b}-1$ to 80b-21; securitization is regulated under the Securities Act of 1933, 15 U.S.C. $\$ \S 77 \mathrm{a}-77 \mathrm{aa}$; and the Securities Exchange Act of 1934, 15 U.S.C. $\$ \S 78 a-78 l l$. See, e.g., James D. Cox, Robert W. Hillman, \& Donald C. Langevoort, Securities Regulation: Cases and Materials 14-20 (1991) (discussing these Acts); Joseph C. Shenker \& Anthony J. Colletta, Asset Securitization: Evolution, Current Issues and New Frontiers, 69 Tex. L. Rev. 1369, 1408-13 (1991) (summarizing recent developments in securities laws). Each of these statutory schemes relies generally on information disclosure rather than mandatory rules.

254. See Hansmann \& Mattei, supra note 248, at 454-58.

255. See id. at 447-51, 459-63.

256. See id. at $471-72$. 
default rule: The rule is adverse to the informationally advantaged parties (the settlor, trustee, and beneficiary) and protective of the informationally disadvantaged party (the third-party creditor). But the rule can be avoided by providing a form of notice to potential creditors, in effect signaling to the third party that the trust assets are not available to satisfy the individual debts of the trustee. ${ }^{257}$ This notice regime works hand in hand with the relatively simple and standardized structure of the trust to reduce the information-cost burden on third parties.

Similarly, when the trustee enters into contracts on behalf of the trust, the trustee will be held personally liable for performance under those contracts, unless the trustee signs the contract "as trustee for X and not individually." 258 Again, the rule operates like a penalty default. The informationally disadvantaged third party is protected, but the trustee can override the rule by making appropriate disclosures alerting the third party that recourse is limited to trust assets only. This rule also lessens the need of individuals generally to inquire into the possible trustee status of potential contracting partners.

3. In Rem Relations. - As in the case of our other borderline institutions, pure in rem situations are hard to uncover within the specialized rules of trust law. Again, however, this is deceptive. Because the trust entails the transfer of full legal title over assets to the trustee, the trustee exercises most of the bundle of in rem rights associated with these assets. Thus, when issues arise that implicate the in rem rights associated with the trust assets, the fact that the assets are held in trust is generally irrelevant to the resolution of these issues. For example, the trustee can sue to evict trespassers from trust property, unaffected by the fact that the trustee holds the property in trust rather than outright. It is thus not surprising that Bogert and Scott do not include sections in their treatises on trust law dealing with these sorts of issues. ${ }^{259}$ The issues are there, but since they have no unique trust aspect they are not dealt with as a feature of trust law.

Where we do encounter in rem issues in trust law, the rules conform to the predicted pattern. Thus, with respect to liability for torts against third parties committed by the trustee in the course of administering the trust, the rule is that the trustee is held personally liable for such torts to the same extent as if she were the fee simple owner of the trust property. ${ }^{260}$ Tort creditors are obviously not in a position to distinguish between trustee and nontrustee tortfeasors. Since contracting is not possible with respect to future tort creditors, the law uses an immutable rule of protection here. Relief for the trustee comes, if at all, only if the trustee has the foresight to include a clause in the original trust document per-

257. See id. at 454-59.

258. Id. at 459-61 (quoting Restatement (Second) of Trusts $\$ 265 \mathrm{cmt}$ a (1959)).

259. George T. Bogert, Trusts (6th ed. 1987); Austin Wakeman Scott \& William Franklin Fratcher, The Law of Trusts (4th ed. 1988).

260. See 3A Scott, supra note 259, at $\S 264$. 
mitting indemnification for tort liability. ${ }^{261}$ Thus, a harm that implicates a large and indefinite number of persons (potential tort victims) is taken care of through the mechanism of an in personam arrangement among the three parties to the trust, but only after assuring that the rights of the tort victim are not affected by the existence of the trust.

There is another general consequence of the in rem dimension of the trust that is relevant to our larger theme about the importance of third-party information costs. The trust as an institution dramatically reduces the information costs of having a system of property rights that includes exotic interests such as life estates, remainders, possibilities of reverter, and executory interests. If life estates and remainders were commonly held as legal interests, ${ }^{262}$ then third parties dealing with property owners would face substantial risks that any particular parcel would be subject to an undisclosed future interest. ${ }^{263}$ Of course, title searches would reveal these interests with respect to real estate. But independent contractors and trade creditors who deal with ostensible fee simple owners of real property will not ordinarily find it economically worthwhile to undertake a title search before providing services. ${ }^{264}$ And future interests in personal property would not be revealed by title searches, since most personal property is not subject to any organized registry. ${ }^{265}$

The popularity of the trust as a means of managing property for the benefit of one or more beneficiaries has rendered the third-party infor-

261. See id.

262. Today the great majority of future interests are created in trusts rather than as legal interests. See Jesse Dukeminier \& James E. Krier, Property 290 (4th ed. 1998).

263. Property subject to an undisclosed future interest such as a possibility of reverter is worth much less than a equivalent parcel of property owned in fee simple, because of the uncertainty about when if ever the interest will vest. Hence the encumbered property would yield much less to creditors in the event of seizure for nonpayment of debts.

264. See Mountain States Tel. \& Tel. Co. v. Kelton, 285 P.2d 168 (Ariz. 1955) (holding that contractor is not deemed to have constructive notice of buried cable that was subject of recorded right of way because those with no interest in the title are not bound to search title to land); Statler Mfg., Inc. v. Brown, 691 S.W.2d 445 (Mo. Ct. App. 1985) (holding no constructive notice to contractor of properly recorded easement for aircraft right of way). Title searches, even if done, provide far from complete protection against surprise. D. Barlow Burke, Jr., American Conveyancing Patterns: Past Improvements and Current Debates 103-04, 120 n.2 (1978) (noting the many risks that American recording systems give rise to and how little protection a title search provides, and citing literature). On the cost of title searches under various systems, see generally Joseph T. Janczyk, An Economic Analysis of the Land Title Systems for Transferring Real Property, $6 \mathrm{~J}$. Legal Stud. 213, 215-26 (1977) (comparing recording system with Torrens system and concluding latter is more efficient); Joseph T. Janczyk, Land Title Systems, Scale of Operations, and Operating and Conversion Costs, 8 J. Legal Stud. 569, 570-75, 582-83 (1979) (evaluating costs of various land title systems and arguing Torrens system should be adopted).

265. Douglas Baird \& Thomas Jackson, Information, Uncertainty, and the Transfer of Property, 13 J. Legal Stud. 299, 306 (1984) (arguing that recording systems for establishing title to personal property are rare because informational advantages are usually not worth the costs); see also id. at 303-04 (noting that "[f]iling systems are not . . . equally suited to all kinds of property," and discussing why). 
mation costs associated with such exotic interests far more manageable. ${ }^{266}$ The corpus of the trust can be bought and sold, invested and reinvested, leased and mortgaged, in the sound discretion of the trustee as if the property were an undivided fee simple. ${ }^{267}$ The complexities of dividing the fruits of these efforts among different generations and classes need not trouble the third parties who deal with the trustee as the manager of the trust corpus. The division is a concern only of the settlor, the trustee, and the beneficiaries, and is dealt with among them as a matter of in personam obligation. In effect, the trust is a brilliant device that allows for considerable customization of beneficial interests using the building blocks of the old common law-thereby reducing the frustration costs associated with strict regimentation of property forms-while at the same time consolidating the assets used to fund these beneficial interests in a form that minimizes third-party information costs.

In this respect, the trust acts like other forms of organization law. The trust's essential function is similar to that of forms of business organization such as limited partnerships and corporations: Trusts partition assets in such a way that third-party creditors need not measure all the credit risk of the assets of the participants involved. ${ }^{268}$ Each of these organizational forms also permits greater standardization in the forms of ownership of basic assets and hence lowers third-party information costs. ${ }^{269}$

\section{E. Summary}

Each of the four institutions we have examined involves some combination of in personam and in rem relations. Bailment involves the in personam transfer of one incident in the bundle of in rem rights-the right of possession-from the bailor to the bailee. Landlord-tenant law involves the in personam transfer of the full menu of in rem rights associ-

266. This point is made indirectly by legal scholars who have argued for a mandatory rule that all exotic future interests (such as remainders, possibilities of reverter, or executory interests) be held in trust. See William F. Fratcher, A Modest Proposal for Trimming the Claws of Legal Future Interests, 1972 Duke L.J. 517, 549-55; Ronald Maudsley, Escaping the Tyranny of Common Law Estates, 42 Mo. L. Rev. 355, 366-67 (1977). The trust alleviates the information costs otherwise imposed on third parties by the existence of these interests. The fact that most exotic interests created today are (for convenience and tax reasons) held in trust, see supra note 262 , helps explain why the legal system has been able to tolerate the continued theoretical possibility of creating such interests.

267. Indeed, in some markets, such as those for securitized assets, trusts may be the only way to establish a secondary market and sell these interests.

268. See Hansmann \& Kraakman, supra note 238, at 412-13.

269. Each of these forms, including the commercial uses of the trust, will ordinarily be used in contexts in which marketability is a primary concern, such as in publicly traded corporations. The need to assure marketability means that there will be great pressure to adopt standard forms in any event. Thus, it may be that in these contexts the functions of the legal rules serve mainly to supply focal points around which more spontaneous standardization will develop. See Merrill \& Smith, supra note 9, at 47 \& n.169. 
ated with property from the landlord to the tenant for a temporary period. Security interests arise with an in personam agreement between a debtor and a creditor to make a transfer of the full bundle of in rem rights to the creditor upon the happening of a future contingent event, nonpayment of the debt. And trusts entail the transfer of the full collection of in rem rights in property from the settlor to the trustee, subject to an in personam obligation on the part of the trustee to devote the property to the benefit of the beneficiary. The mixture of in personam and in rem obligations in each case allows us to study how the legal rules associated with each institution vary as the legal relations shift from in personam problems, through intermediate cases, to in rem issues.

Taken together, the legal doctrine associated with our four institutions provides significant corroboration of the specific hypotheses we set forth at the beginning of this Part about the relationship between the structure of legal rights and third-party information costs. Most strikingly, where we find legal relations that are purely in personam, the legal doctrine quite consistently takes the form associated with contract lawdefault rules that facilitate agreements. In the relatively few areas where the legal relations are purely in rem, we also consistently find that the doctrine adopts the form characteristic of property law-immutable bright-line rules. Moreover, we find substantial evidence that the relations we have labeled compound-paucital are characterized by the legal rules that incorporate a protection strategy designed to overcome problems of incomplete information, and we find evidence that what we have called quasi-multital situations are likely to be dominated by legal doctrines concerned with notice. Finally, as expected we find a tendency for protective and even notice rules to become more difficult to contract around-more standardized-as duty holders become more numerous and indefinite and so closer to the true in rem situation.

To be sure, we have seen deviations in certain circumstances from the specific predictions we set forth for the intermediate situations: Sometimes compound-paucital relations are associated with a notice strategy (as in the law governing mutual funds and securitized assets) and sometimes quasi-multital relations are associated with a protection strategy (as in the law governing misdelivery of bailed goods). Yet even where we find such deviations, they can be plausibly explained by the idea that notice and protection are substitute doctrines in the intermediate areas, depending on whether the development of additional information is likely to be a cost effective solution for problems of incomplete information in any particular context.

A final word is appropriate about the relative paucity of examples of unique legal doctrines that reflect the in rem relations associated with each of our institutions. On reflection, this paucity should not be surprising. We have theorized that in rem rights will be strongly standardized and will incorporate rules for defining resources that are easily understood by a large and indefinite collection of dutyholders. If this is cor- 
rect, then we should expect to find the same basic rules for in rem relations across all institutions. This is in fact more or less what we find: The rules that apply to the in rem dimension of bailed goods are the same as the rules that apply to the in rem dimension of full ownership of goods; the rules that apply to the in rem dimension of leaseholds are the same as the rules that apply to the in rem dimension of fee simple ownership; and so forth. Where we find variation among the institutions is with respect to the default rules that govern the in personam relations and the intermediate situations. This is again to be expected, given that in personam relations impose few information costs on third parties, and hence can accommodate a greater diversity of default rules both across institutions and even within any particular institution.

\section{ConcLusion}

We end where we started, with the question of whether there is some fundamental distinction between property rights and contract rights, or if it is just a matter of repackaging and relabeling. We have argued that at root there is a fundamental difference: The difference corresponds to the distinction between in rem rights and in personam rights, viewed as species of exclusion and governance strategies for controlling the use of resources. This distinction has been obscured by prolonged neglect of the study of in rem rights by legal scholars. Yet once we unpack the features of in rem rights, and the foundation of both in rem and in personam rights in different strategies of exclusion and governance, we can also see why the boundary between property and contract has seemed so fluid. Exclusion and governance are end points along a spectrum of strategies for the control of resource uses, and the differentiating elements of in rem as opposed to in personam rights are present to a greater or lesser degree in different situations. Thus, there are intermediate cases that partake of some of the features of property rights and some of the features of contract.

We do not suggest that our framework will supply the answer to all dilemmas about the line of demarcation between contract and property, such as whether contract rights are "property" for constitutional law purposes. ${ }^{270}$ Other distinctions besides in personam and in rem are also important in demarcating the sphere of contract and property. Sometimes, for example, the distinction between "liability rules" and "property rules"-whether a right can be taken upon the payment of money damages or only with the rightholder's consent-will loom large. ${ }^{271}$ At other times the distinction between rights that expire with the contracting parties and those that run automatically to successors in interest will be of

270. For some tentative thoughts about this issue, see Merrill, Landscape, supra note 2 , at $990-95$.

271. This is the familiar property rule/liability rule distinction. See Guido Calabresi \& A. Douglas Melamed, Property Rules, Liability Rules, and Inalienability: One View of the Cathedral, 85 Harv. L. Rev. 1089, 1092 (1972). 
central importance. ${ }^{272}$ We do believe, however, that the distinction between in personam and in rem rights "is absolutely vital to grasping legally recognized practices like property," 273 and has been overlooked for far too long in both the legal and the economic literature.

Our central point has been to emphasize the importance of the information-cost differences associated with in personam and in rem rights. In personam rights require a small number of identified parties to assimilate a comparatively large amount of information about their respective rights and duties. In rem rights require a large and indefinite number of persons to assimilate a comparatively small amount of information about their respective rights and duties. Because of these differences, the legal rules associated with in personam rights permit a high degree of customization of rights and duties, and emphasize the importance of disclosing information particular to the parties to the in personam agreement. The legal rules associated with in rem rights, in contrast, are standardized and immutable, and focus on gross proxies like boundaries that are easy to observe and grasp by a large and heterogeneous population of dutyholders.

We have sought to test these propositions by examining four institutions that exist along the property/contract interface, where the inherent differences between in personam and in rem rights should be under the maximum stress. By and large we find that even within these institutions, situations that correspond to in personam rights are governed by legal rules that are very contract-like and flexible, and situations that correspond to in rem rights are governed by rules that are very property-like and standardized. Not all the details match up with our more focused predictions. But the overall pattern seems clearly to conform to the information-cost requirements associated with in personam and in rem rights. This we think confirms our central proposition, which is that information costs are key to understanding the features of a system of property rights.

272. This is the familiar issue of whether a right "runs with the land," and is critical in distinguishing between property and contract rights in the law of servitudes. See generally Clark, supra note 53, passim (offering an overview of rights which run with land); Stewart E. Sterk, Freedom From Freedom of Contract: The Enduring Value of Servitude Restrictions, 70 Iowa L. Rev. 615, 615-17 (1985) (reviewing the policy reasons behind existing servitude law, and recognizing the functional component of existing restrictions); A. Dan Tarlock, Touch and Concern is Dead, Long Live the Doctrine, 77 Neb. L. Rev. 804, 805 (1998) (offering a history of the "touch and concern" doctrine and criticizing the proposed 3d Restatement rules).

273. Penner, Idea of Property, supra note 44, at 30 . 